

\title{
The Role of International Reserves Holding in Buffering External Shocks
}

\author{
Jean-Pierre Allegret, Audrey Allegret-Sallenave
}

\section{To cite this version:}

Jean-Pierre Allegret, Audrey Allegret-Sallenave. The Role of International Reserves Holding in Buffering External Shocks. Applied Economics, 2018, 50 (29), pp.3128-3147. 10.1080/00036846.2017.1418075 . halshs-01665908

\section{HAL Id: halshs-01665908 \\ https://shs.hal.science/halshs-01665908}

Submitted on 17 May 2018

HAL is a multi-disciplinary open access archive for the deposit and dissemination of scientific research documents, whether they are published or not. The documents may come from teaching and research institutions in France or abroad, or from public or private research centers.
L'archive ouverte pluridisciplinaire HAL, est destinée au dépôt et à la diffusion de documents scientifiques de niveau recherche, publiés ou non, émanant des établissements d'enseignement et de recherche français ou étrangers, des laboratoires publics ou privés. 
http://economix.fr

\section{The Role of International Reserves Holding in Buffering External Shocks}

Document de Travail

Working Paper 2015-41
Jean-Pierre Allegret Audrey Sallenave



UMR 7235
Université de Paris Ouest Nanterre La Défense (bâtiment G)

200, Avenue de la République 92001 NANTERRE CEDEX université

Paris Ouest

Nanterre La Défense 


\title{
The Role of International Reserves Holding in Buffering External Shocks" \\ Jean-Pierre Allegret* and Audrey Sallenave*
}

\begin{abstract}
An extended literature analyzes the accumulation foreign exchange holding observed in many developing and emerging countries since the 2000s. Empirical studies on the self-insurance motive suggest that high-reserves economies are more resilient to financial crises and to international capital inflows volatility. They show also that pre-crisis foreign reserve accumulation explains post-crisis growth. However, some papers suggest that the relationship between international reserves holding and reduced vulnerability is nonlinear, meaning that reserve holding is subject to diminishing returns. This paper deserves more attention to the potential nonlinear relationship between the foreign reserves holding and macroeconomic resilience to shocks. For a sample of 9 emerging economies, we assess to what extent the accumulation of international reserves allows to mitigate negative impacts of external shocks on the output gap. While a major part of the literature focuses on the global financial crisis, we investigate this question by considering two sub-periods: 1995-2003 and 2004-2013. We implement threshold VAR (TVAR) model in which the structure is allow to change if the threshold variable crosses a certain estimated threshold. We find that the effectiveness of reserve holding to improve the resilience of domestic economies to shocks has increased over time. Hence, the diminishing returns of foreign reserve holding stressed in the previous literature must be qualified.
\end{abstract}

Keywords: Reserve accumulation, Threshold VAR model, Output gap, External shocks, Emerging countries

JEL codes: E52, F30, F41

\footnotetext{
"We wish to thank Marco Jacopo Lombardi and Feng Zhu for sharing their data on shadow federal funds rates, and Rachel Szymanski, Selim Ali Elekdag and Gavin Asdorian for sharing data on the financial stress index.

* EconomiX-CNRS, University Paris Ouest Nanterre La Défense, France. Email: jallegret@u-paris10.fr.

^ LEAD, University of Toulon, France and EconomiX-CNRS, University Paris Ouest Nanterre La Défense, France. Email: audrey.sallenave@,univ-tln.fr.
} 


\section{Introduction}

Since the Asian crisis of 1997-1998, many developing and emerging countries have considerably increased their foreign exchange holding. As a consequence, the repartition of the stock of the world reserves has changed. While in January 2000, developing and emerging countries amounted to 37.1 percent of the world reserves, this share increased to 51.8 percent in December 2005 and 66.6 percent on average from January 2010 to August $2015^{1}$.

An extensive literature analyzes the motives of this accumulation of foreign exchange reserves in such countries (Aizenman and Lee, 2007). A first strand considers that such accumulation results from the promoting exports strategy adopted in several emerging and developing countries. Specifically, reserves accumulation allows countries to prevent or slow domestic currency appreciation. This mercantilist approach has been advanced to explain the revived Bretton Woods system driven by East Asian countries (Dooley and Garber 2005; Dooley et al. 2014) and the currency war in the aftermath of the global financial crisis (Bergsten and Gagnon, 2012; Gagnon, 2013). A second strand of the literature suggests that reserves accumulation responds to a self-insurance motive. Specifically, drawing lessons from the past financial crises, most emerging countries accumulate foreign exchange reserves in order to face recurrent boom-bust cycles in capital inflows. In other words, holding of a sizeable stock of reserves may strengthen their ability to resist to disturbances resulting from the recurrent capital flows instability. Obstfeld et al. (2010) investigate a large sample of 134 developing, emerging, and advanced countries spanning the period 1993-2004. They show that financial stability variables improve regressions explaining the worldwide reserves built-up, particularly since the late 1990s. Pina (2015) develops a theoretical model in which reserve holding allows the central bank to smooth inflation in the aftermath of banking sector support during a banking crisis. Such relationship suggests a positive correlation between the size of the financial sector -insofar as inflationary pressures due to the occurrence of a financial crisis increases with this size - and reserve accumulation. Empirical studies on the self-insurance motive suggest that high-reserves economies are more resilient to financial crises and to international capital inflows volatility. Analyzing the experience of a sample of emerging countries over the period 1970-2010, Aizenman and Hutchison (2012) find that the positive correlation between output volatility and the degree of financial openness does not hold in countries with high levels of international reserves. In other words, accumulating sizeable international reserves allows improving trade-offs between monetary independence, financial openness, and exchange rate stability implied by the impossible trilemma (Aizenman et al. 2013; Aizenman and Ito, 2014). For a sample of 72 countries over the period 1970-2011, Catão and

\footnotetext{
${ }^{1}$ IMF, International Financial Statistics Database.
} 
Milesi-Ferretti (2014) show that higher holding of international reserves reduce the likelihood of external crises. ${ }^{2}$ Alberola et al. (2015) find that large stocks of foreign reserves pay off to mitigate gross capital outflows during periods of systemic financial stress. Gross foreign inflows are not significantly affected by reserve holding. Importantly, when introducing non-linear effects through quadratic terms, Alberola et al. (2015) show that reserve holding exhibits decreasing returns. In other words, growing reserve accumulation is less and less effective to reduce capital outflows. The global financial crisis has offered an opportunity to see to what extent holding a sizeable amount of foreign exchange reserves has mitigated the negative impact of the crisis on output. While Blanchard et al. (2010) do not find a relationship between holding a large amount of reserves -proxied through the ratio of reserves to short-term debt- and output loss during the crisis for a sample of 29 emerging countries, many studies find the opposite. For instance, Bussière et al. (2015) assess to what extent pre-crisis foreign reserve accumulation explains economic growth during the crisis. For a sample of 129 developing countries and 32 emerging economies, they find that the accumulation of international reserves during the period preceding the crisis positively contributes to the real GDP growth during the crisis. In a similar way, Dominguez et al. (2012), by investigating the relationship between reserve holding prior to and during the global financial crisis, and real GDP growth in the aftermath of the crisis, get two main findings. First, they show that the larger the reserve holding before the crisis, the higher has been post-crisis growth. Second, depletion of reserves during the crisis tends to improve growth performances in the post-crisis period, but this depletion is conditional to the accumulation of reserves in the pre-crisis period. Dominguez (2014) analyzes the relationship between reserve holding and exchange rate realignments among non-eurozone European countries during the global financial crisis. She finds that countries having accumulated reserves before the crisis and willing to deplete them in times of crisis succeed to stabilize their exchange rate during the global financial crisis.

Importantly, using different measures of output performances during the financial crisis and different reserves coverage ratios, Llaudes et al. (2010) and Berkmen et al. (2012) stress that the relationship between international reserves holding and reduced vulnerability is nonlinear. Such result suggests the presence of threshold effects. Specifically, if Berkmen et al. (2012) show that countries with higher international reserves experienced smaller growth revisions, the relationship is statistically insignificant. Llaudes et al. (2010) confirm that higher international reserves ${ }^{3}$ can

\footnotetext{
${ }^{2}$ External crises refer to external defaults, rescheduling events and sizable financial supports from international financial institutions. Results from Catão and Milesi-Ferretti (2014) suggest that external crises tend to occur in countries with reserves to GDP ratios lower than $2 \%$.

${ }^{3}$ Llaudes et al (2010) consider the ratio reserves over external requirements (sum of the short-term external debt (at residual maturity) and the current account deficit).
} 
help to buffer the impact of the financial crisis. But they show that international reserves holding exhibits diminishing returns. Indeed, at very high levels of reserves holding, the moderating impact on output collapse seems disappear.

This paper deserves more attention to the potential nonlinear relationship between the foreign reserves holding and macroeconomic resilience to shocks. More precisely, for a sample of 9 emerging economies -Brazil, Chile, Hungary, Indonesia, Mexico, Russia, South Korea, Thailand, and Turkey- we assess to what extent the accumulation of international reserves allows to mitigate negative impacts of external shocks on the output gap. While a major part of the literature focuses on the global financial crisis, we investigate this question by considering two sub-periods: 1995-2003 in which several emerging markets crises occur; 2004-2013 characterized by the global financial crisis and the European sovereign debt crisis. In other words, we identify reserves threshold not only for the global financial crisis, and investigate to what extent reserves detention above the threshold implies lower output loss in the aftermath of external shocks. This is our first contribution to the literature. To our best knowledge, no paper investigates systematically the relationship between reserves holding and macroeconomic performance using a non-linear framework. To this end, we implement threshold VAR (TVAR) model in which the structure is allowed to change if the threshold variable crosses a certain estimated threshold. Specifically, the system's dynamics is modified between two regimes, namely high reserves detention and low reserves detention. Importantly, the switching variable is not determined exogenously but endogenously via linearity based test. The generalized impulse response functions addresse the question whether monetary, trade and financial shocks have different effects on output gap during both high detention and low detention reserves. This is our second contribution to the literature. Finally, we contribute to the debate on the sub-optimality of reserves accumulation. Rodrik (2006), among others, considers that reserves accumulation is costly. Indeed, as such reserves are invested in safe international assets offering very low returns; this form of national saving -recall that current account surplus means an excess of domestic saving over domestic investment- is not optimally used.

Our main finding is that the diminishing returns of reserve holding stressed in the literature must be qualified. Indeed, we show that output damages due to trade, monetary, and financial shocks tend to be mitigated when authorities hold reserve above a specific threshold.

The rest of this paper is structured as followed. Section 2 presents the variables, periods, and countries included in this paper. Section 3 is dedicated to the econometric methodology. Section 4 comments the results. Section 5 concludes. 


\section{Variables selection and sample period}

In this paper, we assess to what extent foreign reserves holding mitigates output loss during crises using monthly data. ${ }^{4}$ So, our first variable of interest is the estimation of the output loss. Industrial production is the most frequently used indicator. However, its main drawback is to exclude important part of the economic activity, mainly services industries whose influence is growing over time. For this reason, we favor the gross domestic product (GDP). In a first step, as GDP is available only at quarterly frequency, all series are interpolated with the Chow and Lin (1971) methodology. This methodology, based on multivariate general least squares, allows us to derive monthly estimates from annual GDP figures. More specifically, we use the monthly industrial production as the latent variable to obtain a proxy of the monthly GDP. In a second step, in order to estimate a measure of output loss, GDP are detrended with the HodrickPrescott filter. Thus, our measure of output loss is the cyclical component of GDP, namely the output gap. This measure is somewhat rough to the extent that it does not take into account the return to pre-crisis level, but it seems more tractable for the empirical model used in sections 3 and 4 .

Our countries sample is representative of the reserve accumulation behavior observed in emerging markets. Figure 1 portrays the change in foreign exchange holding in the sample countries from 1995 to 2013. While reserve holding worldwide have raised about 6.5 times from 2000 to 2013, for emerging and developing economies this ratio is more than 11.8, and for our sample it is 6.7. So, countries included in this paper are typical of the foreign reserves accumulation in emerging economies. ${ }^{5}$ In addition, these countries share come common features explaining their growing sensitivity to external shocks. On the one hand, their level of trade openness significantly increased in all countries but Indonesia till the global financial crisis. On the other hand, gross international capital flows have increased in scale. More precisely, except Indonesia for liabilities side, all studied countries have experienced a rise in stocks of both foreign assets and liabilities. Such evolution has gone hand in hand with domestic financial deepening. Increase in portfolio equity liabilities has been especially important in Latin American and SouthEast Asian economies. While international banking flows have been an important driver of gross flows in the 2000s, this characteristic is especially significant for Hungary in our sample.

Figures $2 \mathrm{a}$ and $\mathrm{b}$ exhibit the output gap for the 9 emerging countries studied and the two subsamples. On table 2, specific episodes of banking, sovereign, and currency crises are given. Except Hungary and, to a lesser extent Turkey, for the first sub-period (1995M1-2003M12), a

\footnotetext{
${ }^{4}$ For definitions and sources of the variables, see Table 1 in Appendix. All Tables and Figures are in Appendix.

${ }^{5}$ This amount hides an important heterogeneity as the highest increase in observed in Russia (51.2) and the lowest one in Chile (2.9). The median increase is 4.8 and the average 10.1
} 
striking feature of these figures is the cluster of sizeable negative output gap during particular periods. Specifically, if one considers a negative output gap at least of -1.5 point, we identify one cluster from 1998M1 to 1999M12 and a second cluster from 2008M9 to 2009M12. Such comovements in the output gap result from the systemic dimension of the Asian and Russian crises (for the first sub-period) and the global financial crisis in the aftermath of Lehman Brothers collapse in September 2008. Importantly, they result also from some common external shocks that hit emerging countries.

As we are particularly interested by commonalities across our sample countries, three external shocks are considered. They match with the three main international transmission channels present in the literature, namely trade, monetary, and financial channels.

As a proxy of international trade shock, the index of global real economic activity in industrial commodity markets is used. Indeed, G7 activity index is too restrictive considering the growing weight of emerging economies in the world economy while G20 index may pose serious endogeneity problems. In addition, the index of global real economic activity in industrial commodity markets performs very well to capture changes in the world activity. ${ }^{6}$ This index is constructed from representative single voyage freight rates collected by Drewry Shipping Consultants Ltd. for various bulk dry cargoes such as coal, iron ore, fertilizer, and scrap metal (Kilian, 2009).

Since the onset of the global financial crisis in 2008, identifying the stance of monetary policy is particularly challenging. Indeed, not only policy rates in major countries are set at their Zero Lower Bound, but central banks implemented unconventional policies through forward guidance and quantitative easing. As a result, using policy rates as a proxy of the international monetary shock is inappropriate as they are non-informative about monetary policy stance. We follow the recent literature on monetary policy and use a shadow policy rate. The challenge is twofold in the estimation process: on the one hand, the shadow policy rate must be directly comparable to the policy rate announced by central banks; on the other hand, it must be informative on unconventional monetary measures. In this paper, among the different estimations used in the literature (Hakkio and Kahn, 2014), we choose the shadow policy rate calculated by Lombardi and Zhu (2014). First, it is available on a more extended period than the Wu and Xia rate.

\footnotetext{
${ }^{6}$ We performed different estimations, using different indicators such the G7 industrial production index and the imports from G7. None of these indicators provide better results than the index of global real economic activity in industrial commodity markets. Results are available from the authors upon request.

${ }^{7}$ The shadow policy rate is estimated with a pooling of a comprehensive dataset concerning the conduct of monetary policy. The information is summarized using a dynamic factor model. The shadow policy rate is constructed from the estimated factors that represent different aspects of monetary policy.
} 
Second, the estimated level of the shadow rate fits better the Wu and Xia one than the Krippner shadow rate. ${ }^{8}$

As a measure of the international financial shock, a larger indicator than VIX has been preferred. Specifically, considering the significant worldwide influence of the U.S. financial conditions, the financial stress index (FSI) constructed by Cardarelli et al. (2008) is included in our model. The FSI is a composite indicator encompassing the main characteristics of financial stress events: large shifts in asset prices, an abrupt increase in risk and/or uncertainty, liquidity droughts, and concerns about the health of the banking system. ${ }^{9}$ Interestingly, Balakrishnan et al. (2011) show that, on average, close to 70 percent of stress in developed economies is transmitted to emerging economies. In addition, they find that the transmission is fast: it takes only one to two months to reach emerging economies. ${ }^{10}$

After defining the shock retained in our model, it is important to explain their behavior during the two periods. Figures $3 \mathrm{a}-\mathrm{f}$ show the evolution of the shocks over the two sub-periods analyzed. Shaded areas correspond to what we consider as times for which a specific shock is particularly important. To identify such times, we estimate the trend - using Hodrick-Prescott filter - and consider that periods when a specific shock variable is above (for the monetary and financial shocks) and below (for trade shock) its trend, so, this period can be qualified as particularly unstable for emerging economies included in the sample.

Figures $3 \mathrm{a}-\mathrm{f}$ suggest that shocks identified correspond well to the main events that hit emerging economies during the two sub-periods. At the beginning of the first sub-period, the main concerns are the simultaneity of international monetary shocks - due to the tightening of U.S. monetary policy in February 1994 - and international financial stress in the aftermath of the Mexican crisis. During the waves of currency crises spanning the period from end-1997 to end1999, international trade and financial shocks are the main disturbances affecting emerging countries. Over the period January 2000 - March 2003, we observe the combination of international monetary and financial shocks. While the first shock precedes the ICT bubble

\footnotetext{
${ }^{8}$ However, it is important to stress that the Lombardi and Zhu shadow rate exhibits the higher volatility relative to the Wu and Xia, and Kripnner rates.

${ }^{9}$ The FSI is a combination of sub-index relative to banking-related variables ( the "beta" of banking sector stocks, the TED spread, and the slope of the yield curve), securities-market-related variables (corporate bond spreads, stock market returns, and time-varying stock return volatility), and foreign exchange variable (time-varying effective exchange rate volatility). Alternative financial conditions index are: the National Financial Condition Index published by the Federal Reserve Bank of Chicago that considers as subindexes risk (volatility, funding risk), credit (measures of credit conditions), and leverage (debt and equity measures); and the St. Louis Fed Financial Stress Index built by the Federal Reserve Bank of St. Louis that includes 7 interest rate indicators, 6 yield spreads indicators, the EMBI, the VIX, the Merril Lynch bond market volatility index, the 10 year breakeven inflation rate, and S\&P 500 financials index. These three indexes exhibit almost similar results to detect financial stress periods. See Hakkio and Keeton (2009), and Bravea and Butters (2012).

${ }^{10}$ The comovement parameters, however, vary substantially across countries, ranging from close to zero for Pakistan, Hungary, and China, to more than one for Chile and Turkey.
} 
collapse, the second appears particularly important in the aftermath of the speculative bubble collapse. The second sub-period was marked by three phases of especially high tensions. First, from August 2005 to September 2006, international trade and monetary shocks are mainly driven by the tightening of U.S. monetary stance to decrease inflation pressures. Second, not surprisingly, the bankruptcy of Lehman Brothers led to a collapse of international trade and a freezing of international credit markets. As a result, from November 2008 to May 2009, international trade and financial shocks were especially sizeable. Third, from 2012 to the end of the studied period, world economy experiments two main disturbances: the European sovereign debt crisis and the U.S. tapering announcement (May 2013). These two shocks increased uncertainty about the strength of the economic recovery and the timing of the monetary policy tightening. As a result, international trade and monetary shocks tend to dominate over this period.

In sum, the external shocks retained in this paper fit the major international disturbances that affected emerging markets. In addition, the periods in which they were most intense correspond to phases where output gaps have been more negative.

Following Buissière et al. (2015), we use in our estimations the following three indicators:

- the foreign exchange reserves in percentage of GDP. This GDP based indicator allow to control for country size;

- the foreign exchange reserves in percentage of external short-term debt. The debt based indicator rests on the Greenspan-Guidotti rule that requires foreign exchange reserves to cover the stock of short-term debt. This ratio is especially important with the financial integration of emerging economies;

- the foreign exchange reserves in percentage of M2. This money based indicator refers to the use of foreign reserves to stabilize domestic financial markets (Obstfeld et al., 2010). Specifically, as stressed by Sachs et al. (1996), this ratio shows the extent to which liquid domestic liabilities of the banking system are backed by foreign exchange reserves. Thus is a measure of the banking system's ability to withstand currency pressures and, more broadly, about domestic financial markets.

\section{Methodology}

The empirical framework is conducted by estimating a Threshold Vector Autoregression (TVAR) introduced by Balke (2000). This class of model has many interesting features. It allows to capture nonlinear effects by disentangling asymmetric reactions in a structural VAR that may be due either to periodic movements or regimes changes, as suggested in a number of economic and monetary policy models like Terasvirta and Anderson (1992) or Holmes and Wang (2000). More 
specifically, this approach is an interesting tool to separate the data in different regimes in a relatively simple and intuitive way ${ }^{11}$.

We attempt to capture the role of foreign exchange reserve holding that allow authorities to face the impact of various external shocks on output gap. As we aim at examining if the levels FOREX to GDP ratio cause a regime shift in the output gap for our countries, we cannot perform linear models such as structural VAR. Indeed, linear models are too restrictive, and are not able to adequately capture asymmetries that may exist in business cycle ${ }^{12}$ and more generally for macroeconomic time series.

We consider the following single-threshold VAR model:

$Y_{t}=B_{1}+\gamma_{1}(L) Y_{t}+\varepsilon_{1 t}+\left(B_{2}+\gamma_{2}(L) Y_{t}+\varepsilon_{2 t}\right) I\left(y_{t-d}^{*}>\theta\right)$

where $Y_{t}$ is a vector containing the output gap, the monetary shock, the trade shock and the financial shock. $\varepsilon_{1 t}$ and $\varepsilon_{2 t}$ denote respectively vectors of orthogonal shocks.

The indicator function $I$ is equal to one when the $d$-lagged threshold variable $y_{t}^{*}$ is higher than the threshold $\theta$ and zero otherwise. The delay parameter $d$ implies that if the threshold variable crosses the threshold value of $\theta$ at time $t$ - $d$, then the dynamics actually change at time $t$. Last, the lag polynomials $\gamma_{1}(L)$ and $\gamma_{2}(L)$ describe the dynamics of the TVAR system. The lag length of the endogenous variables, $p$, is determined by the usual information criteria (Akaike). We use most of the time only one lag, due the low number of observations in one of the two regimes.

The model identifies two separate regimes based on the value of the $d$-lagged threshold variable relative to $\theta$ which is endogenously determined in the system.

From equation (1) we see that this model allows the dynamics of output gap to change if the reserve holding ratio is below or above the critical threshold value. More specifically we see that the coefficients of the TVAR model are allowed to change across states depending on the level of each threshold variable- According to Hansen (1996, 1997), the transition variable can be either an endogenous or an exogenous variable. Since VAR model considers all variables in the system as endogenous, shocks to any of the variables in $Y_{t}$ may induce a shift to a different regime.

An important issue concerning the TVAR models may be the endogeneity coming from the fact that our threshold variable is allowed to endogenously respond to our shock variables. To address this problem that may occur we impose the threshold variable to switch across states with a delay. Then, we evaluate each of our shock variables within a certain date. We also

\footnotetext{
${ }^{11}$ Seminal papers on nonlinear autoregressive models were developed by Tong (1978, 1983, 1990) who employed threshold autoregression (TAR) models. This paper extends the Tong (1983) univariate threshold model to a multivariate framework, namely a threshold VAR (TVAR) model launched by Balke (2000).

${ }^{12}$ See Beaudry and Koop (1993), Potter (1995) or Pesaran and Potter (1994).
} 
consider a two-period-moving average process for the threshold variable in order to have some persistence in the variation of the threshold variable before shocks cause the regime switching.

\subsection{Testing the nonlinearity}

Prior to the estimation, the first step is to test the non-linearity of each equation of the TVAR. To define the threshold of the switching variable, we can either choose arbitrarily the value of this variable, or basically estimated it from the model. As the threshold value is typically unknown a priori, we have to estimate it. This involves nonstandard inference because the value of the threshold $\gamma$ is not identified under the null of non threshold behavior ${ }^{13}$. In this analysis, the threshold value is determined endogenously by least squares using a grid search over possible values of the threshold variable. To prevent overfitting, we follow the approach of Hansen (1996) and limit the possible threshold value so that each regime includes at least $15 \%$ of the observations plus the number of parameters for each individual equation in the VAR. Then, the estimated threshold value corresponds to the estimated model with the smallest determinant of the variance covariance matrix of the estimated residuals:

$\theta^{*}=\operatorname{argmin} \log \left|\Omega_{\varepsilon}(\theta)\right|$

where $\theta^{*}$ is the estimated threshold value and $\Omega_{\varepsilon}(\theta)$ the variance covariance matrix of the estimated residuals.

Following Hansen (1996) and Balke (2000), we compute three different Wald test statistics over all possible threshold values: First the sup-Wald which is the maximum Wald statistic over all possible threshold variables and threshold value. Second, avg-Wald which is the average Wald statistic over all possible threshold and threshold values. Third, exp-Wald which is a function of the sum of exponential Wald statistics. Under the null, we specify that the coefficients of $B_{2}$ and $\gamma_{2}(L)$ of (1) are equal to zero. Results are reported in table 3 for each sub-period. The sup-Wald, avg-Wald and exp-Wald, the estimated threshold variable and the threshold value are presented. All tests, for each sub-period reject the null hypothesis of linearity against the threshold alternative at the $5 \%$ level.

\subsection{Nonlinear generalized impulse response functions}

In the case of a simple linear model, an impulse response function is defined as the difference between two different realizations of $Y_{t+n}$ that are identical up to $t-1$. One realization assumes

\footnotetext{
${ }^{13}$ As the threshold value is unknown under the null, standard inference cannot be applied and asymptotic $p$-values need to be derived using a bootstrap approximation as in Hansen $(1996,1997)$. The algorithm involves the following steps. First, we generate a random sample, $\varepsilon_{t}^{*}$, by sampling with replacement from the estimated residuals, $\hat{\varepsilon}_{\dot{t}}$. Then we simulate a sample, $Y_{t}^{*}$, by feeding the model with the random residuals $\varepsilon_{t}^{*}$, the estimated coefficient matrices, and the fixed initial conditions $\left(Y_{0}, Y_{-1}, Y_{-2}, \ldots, Y_{-p+1}\right)$, where $p$ is the number of lags in the VAR. This simulation is repeated 1000 times. The bootstrap $p$-value is equal to the share of simulated Wald statistic values which exceed the observed Wald statistic value. If linearity is rejected, then the endogenously chosen threshold value separates the observations of the transition variable into different regimes that are described by a linear model.
} 
that between $t$ and $t+n$ the system is hit only by a shock of size $\delta$ at period $t$, while the second realization, taken as the benchmark, assumes that the system is not hit by any shocks between $\mathrm{t}$ and $t+n$. More specifically, we are able to answer the question of the effect of a shock of size $\delta$ hitting the system at time $t$ and $t+n$ given that no other shocks hit the system.

As we see, the linear case is straightforward compared to the nonlinear case. The latter requires further impulse responses definitions that account for the nonlinearity of the system. The shock must depend on the entire history of the system before the point at which the shock occurs. ${ }^{14}$ Moreover, linear impulse responses functions are inappropriate since they are historyindependent, symmetric (i.e., negative shocks are exactly the opposite of positive shocks) and proportional to the size of a shock. In a nonlinear specification, we expect that the effect of a shock is not proportional to its size or direction and that it is history-dependent. To cope with these issues, we use generalized impulse response functions (GIRF) that are applicable to both the linear and the nonlinear model.

We follow Koop et al. (1996) to implement the generalized nonlinear impulse response functions (nonlinear GIRFs). ${ }^{15}$ Generalized nonlinear impulse response functions are defined as the difference between the forecasted paths of variables with and without a shock to a variable of interest. Formally, the GIRF is defined as:

$\operatorname{IRF} F_{Y}\left(n, u_{t}, \Omega_{t-1}\right)=E\left[y_{t+n} \mid \Omega_{t-1}, u_{t}\right]-E\left[y_{t+n} \mid \Omega_{t-1}\right]$

where $\Omega_{t-1}$ is the information set at time $t-1$. The size and the sign of the shock and the initial conditions of the regime that the economy is starting in $\Omega_{t-1}$, are required to calculate the impulse responses. The conditional expectations $E\left[y_{t+n} \mid \Omega_{t-1}, u_{t}\right]$ and $E\left[y_{t+n} \mid \Omega_{t-1}\right]$ are computed by simulating the model. The nonlinear impulse responses can be simulated by randomly drawing vectors of shocks $u_{t+j}$ for $j=1$ to $k$ and then simulating the model conditional on an initial condition $\left(\Omega_{t-1}\right)$ and for a given realization of $u_{t}$. The simulation is repeating for $u_{t-j}$ so as to eliminate any asymmetry that might arise from sampling variation in the draw of $u_{t-j}$. This is repeating 500 times, and the resulting average is the estimated conditional expectation. To capture the potential asymmetry, the responses can be simulated by letting each shock enter the model with different sign (positive or negative) and different size (one or twostandard-deviations).

\footnotetext{
${ }^{14}$ See among other Gallant et al. (1993) Koop (1996) and Koop et al. (1996).

15 We follow Koop et al. (1996) to derive the confidence bands from the quantiles of the distribution of the average impulse responses. Results are available upon request.
} 


\section{Results}

This section investigates to what extent foreign exchange holding allows authorities to smooth the impact of external shocks on output gap. To this purpose, three shocks -trade, monetary, and financial- are included in TVAR models by decomposing the period 1995-2013 in two subperiods. This decomposition has two main objectives. On the one hand, we consider that the effect of reserves holding is time specific. Hence, assessing the potential stabilizing impact of reserves implies to consider different crises episodes over time; and, above all, periods preceding the rising accumulation in foreign reserves since 2000s (Figure 1). On the other hand, the sensitivity of countries to different external shocks changes over time.

Specifically, a close inspection of IRFs displayed in Figures 4a-b highlight this time-varying impact of external shocks. During the first sub-period, Latin American countries exhibit similar picture. Except in 1995 in the aftermath of the Mexican crisis, these countries appear relatively insensitive to monetary shocks. Indeed, around the waves of crises in emerging markets at the end of 1990s, their output gap tends to respond to trade and financial shocks. At the beginning of the 2000s, trade shocks are especially important for Latin American countries. Similarly, Asian countries share a number of common characteristics. Specifically, in the aftermath of Mexican crisis, external monetary and financial shocks are the main disturbances explaining the behavior of output gap. Interestingly, while in the first half of 1998, the three Asian economies studied in this paper have been hit by trade and monetary shocks, we see that until end-1999, main disturbances are trade and financial shocks. As for Latin American countries, trade shocks have particularly affected output gap in the Asian area at the end of the first sub-period. Emerging European countries follow a less regular path. However, Figures 4a-b suggest a higher sensitivity to external trade shocks. Such sensitivity may rest on the weight of oil in exports (Russia) and current account deficits (Hungary and Turkey). In the wake of Asian and Russian crises, external financial shocks exert a significant influence on output gap. As expected, over the sub-period 2004-2013, negative output gap responses have been largely driven by financial and trade shocks. The systemic dimension of the global financial crisis explains the similarities among our studied countries in 2008-2009. In addition, except Hungary, from 2012 to 2013, all external shocks interacted simultaneously to impact output gap. To assess the effectiveness of reserve holding, it is important to consider the size of the output gap responses to external shocks.

The foreign exchange reserves in percentage of external short-term debt and the foreign exchange reserves in percentage of M2 are particularly related to financial vulnerabilities affecting emerging economies. An extensive literature points on liability dollarization as the main vulnerability indicator. Indeed, liability dollarization to negative balance sheet effects when 
domestic currency depreciates in the aftermath of external shocks. Berkmen and Cavallo (2010) distinguish three measures of dollarization, each focusing on a specific dimension. The external dimension estimates liability dollarization by considering countries' foreign currency liabilities against the rest of the world. The official dimension refers to public sectors' domestic debt dollarization. The banking dimension encompasses deposits dollarization. As banks are especially prone to to balance sheet effects, figure 5 exhibits the ratio of foreign liabilities in the domestic financial sector relative to money stocks. Following Levy-Yeyati et al. (2010), this ratio is our proxy to assess the size of the currency mismatch and, in turn, the level of the financial vulnerability.

Over the first subperiod, Mexico (1995-2001), Indonesia (1997-98), South Korea (1997-98), Thailand (1995-2000), and Turkey (1997-2002) experienced ratios greaterthan one, suggesting the presence of a significant currency mismatch. Figure 5 shows the increase in the degree of currency mismatch in Russia just before the Russian crisis in August 1998. Over the second subperiod, currency mismatch appears particularly important in Hungary (2007-2009) and Russia (2004-2009). In addition, South Korea financial vulnerability increases from 2006 to 2009.

We analyze successively the impacts of trade, monetary, and financial shocks on output gap using the first indicator as the benchmark model. Our analysis considers only significant responses. ${ }^{16}$ The section concludes with robustness tests using the last two indicators.

\subsection{Trade shocks}

Over the period 1995-2003, except South Korea, Hungary, and Russia, High regime exhibits better output gap performances on the impact of the shock. However, Figure 4a suggests that the stabilizing role of reserve holding is observed mainly at short-term. For instance, in Latin American countries, better performances of High regime lasts less than 12 months. In South-East Asia, except Indonesia, Low regime exhibits lower output gap loss immediately after the impact of the shock. Considering the whole sub-period, we find that High regime outperforms only in two countries -Indonesia and Turkey- while Lower regime provides better performances at all time horizons for Hungary and Russia.

However, fluctuations in output gap deserve more attention. Interestingly, the IRFs show that the High regime tends to imply smoother adjustment of output gap than the Low regime.

Overall, results concerning the effectiveness of reserve holding are mixed. On the one side, with regards to the size of the output gap loss, reserve holding seems beneficial only at short- and medium-term. On the other side, the magnitude of fluctuations in both regimes suggests that the High regime reduces output volatility.

\footnotetext{
${ }^{16}$ Insignificant responses are indicated by letters "NS" in Figures 5a-b. For detailed results, see Figures 6a-g.
} 
On the impact of the trade shock, a striking result over the period 2004-2013 is that Low regime underperforms in terms of output gap loss (Figure 4b). Chile and Russia -two countries particularly dependent on commodity exports- are important exceptions. In addition, except for Chile, shock adjustments are smoother in the High regime, suggesting once again that reserve holding allow reducing volatility in the aftermath of trade shock.

Such results are even more remarkable that the 2004-2013 period was characterized by sizeable external trade shocks (Figure 3f).

Responses of output gap to trade shocks over the two sub-periods suggest an increasing effectiveness of reserve accumulation in the latter relative to the former. Indeed, while output losses are lessened at both short- and long-term horizon in the High regime over the second subperiod, such result is observed only at long term during the first sub-period. However, whatever the sub-period, reserve accumulation tends to decrease output volatility.

\subsection{Monetary shock}

From 1995 to 2003, on the impact of the shock, the accumulation of foreign exchange reserves improves the ability of authorities to face the increase in U.S. interest rate. Indeed, when significant, in all countries except Indonesia and, to a lesser extent, Russia, the output gap is less affected by the shock in the High regime. In most of the studied countries, the stabilizing effect of reserve holding is observed over 12 months. Specifically, IRFs portrayed in Figure 4a shows that this effect lasts at least 17 months in 4 out of 5 countries. In other words, in countries where the responses of output gap have been particularly important -Indonesia, Russia, South Korea, and Thailand- an interesting finding is that reserve holding has been effective to stabilize output gap in the aftermath of the external monetary shock. However, results suggest that High regime does not favor smoother adjustment of the output gap.

For the second sub-period, the IRFs lead to a striking conclusion: reserve accumulation does not seem to exert a sizeable influence of output gap responses to external monetary shocks. Thus, on the impact of the monetary shock, we see that High regime exhibits better responses in only 3 countries (Chile, Thailand, and Russia) out of 9. At longer horizon, it outperforms in Chile, Indonesia, Mexico, Thailand, and Turkey. A closer inspection of the results shows that reserve holding does not improve output gap resilience in Brazil and South Korea, and in Mexico, Hungary, and Russia at 12-24 months. Finally, except in Brazil, Russia, and Turkey, adjustments are smoother in the High regime.

As stressed above, to assess the effectiveness of reserve holding it is important to consider the specificity of this sub-period. Indeed, after an initial tightening of U.S. monetary policy from 2004 to-mid 2006, the stance of monetary policy has been biased toward an expansionary path, 
particularly after the Lehman Brothers collapse in September 2008. A different way to highlight such an expansionary bias is to stress that in 7 out of 9 countries, the responses of the output gap to the monetary shock are positive on the impact in either regimes or both. In the remaining economies, the size of the negative responses is very small. In addition, Figure $3 \mathrm{~d}$ shows that external monetary shocks have been more significant at the end of the period (2012-2013).

Overall, we find that when international monetary shocks are particularly important, as for the first sub-period, reserve accumulation improves the ability of the authorities to face such shocks.

\subsection{Financial shocks}

The IRFs suggest that the effectiveness of reserve holding is relatively weak over the first subperiod. On the one hand, the High regime outperforms over all time horizons in only two countries (Chile and Mexico). On the other hand, the short-term stabilizing influence of the High regime is slightly weaker than at long-term. Specifically, after 24 months, the output gap is less affected in the High regime in 4 countries out of 7 while reserve holding is effective at the impact in 3 economies. Low regime over-performs in the aftermath of external financial shocks at all time horizons in Hungary and Russia. In South Korea, reserve holding is effective at long term while it over-performs in Thailand only at the impact. These results are notable insofar as the previous economies suffer particularly from external financial shocks during the Asian-Russian crises. Shock adjustments analysis confirms the ineffectiveness of reserve holding. Indeed, either the adjustment processes are similar or the High regime exhibits more volatility.

In the aftermath of Lehman Brothers collapse, international financial stress has been particularly important. Interestingly, our results show that the High regime has significant stabilizing properties. At very short-run, we find that output gap is more resilient in 4 countries (the exceptions are Brazil, Indonesia (but responses are very similar), Thailand, and South Korea). The effectiveness of reserve holding is not a short-term phenomenon. Thus, after 12 and 24 months, foreign exchange accumulation exerts a stabilizing influence in the major part of our countries. Reserve accumulation does not reduce output gap damages in the aftermath of the external financial shocks in Brazil (except at long-term), Indonesia (at all horizons), and Hungary (except at the impact). In addition, the effectiveness of reserve holding is confirmed by the fact that shock adjustments are smoother in the High regime.

A comparison of the two periods leads us to a striking result: while financial shocks have been significant over the two periods, reserve accumulation was much effective for the sub-period 2004- 2013. 


\subsection{Robustness check}

In order to check the robustness of the results, we perform similar estimates for two alternative threshold variables: the ratio reserves over short-term external debt and the ratio reserves over the monetary aggregate M2. Table 3 shows the respective threshold values for our sample. The main purpose of this robustness investigation is to draw general lessons about the effectiveness of reserve accumulation. Broadly speaking, we find that our results are robust to alternative threshold variables specifications.

More specifically, in the time period spanning from 1995M1 to 2003M12, results for the external short term debt model (Table 4) are robust for both trade and monetary shocks at the three time horizons. In other words, reserve accumulation tends to increase the resilience of output to these external shocks. When M2 is the threshold variable, table 5 suggests that High regime exhibits better performances for monetary shock, and, to a lesser extent, trade shock. This latter result suggests that reserves indicators closely related to financial system do not capture very well external shocks due to real variables. As we will see below, such finding is confirmed in the second subperiod. Interestingly, financial vulnerabilities - proxied by currency mismatch (Figure 5)- all threshold variables show that financial vulnerabilities decrease the ability of reserve accumulation to immunize output to trade shocks. This result is particularly striking for Russia and Thailand. Focusing on external financial shocks, we find a close relationship between the level of currency mismatch and the effectiveness of reserve holding. Indeed, for Indonesia, South Korea, and Russia, the three alternative threshold variables exhibit a similar path: reserve accumulation does not influence the resilience of output gap. In Mexico, Thailand, and Turkey, two out of three alternative variables show the weak effectiveness of reserve holding to face external financial shocks. Finally, for countries with low currency mismatch, alternative econometric specifications confirm the effectiveness of reserve holding to cope with such shocks.

Over the period 2004-2013 for the reserve to short-term debt model, on the impact of the trade shock, for all countries but Brazil and Turkey FOREX accumulation protect domestic economies against external trade shocks. The same conclusion for Brazil and Turkey is obtained with the reserve to M2 ratio model. As stressed above, M2 as a threshold variable provides less robust results for trade shocks. Thus, we see that at the medium and long term, results are much more demeaned compared to the benchmark model. As for the reserve to GDP model, excepted at the impact, results for the monetary shock are mostly in favor of low FOREX holdings. It is important to be cautious by interpreting this finding as aver the second subperiod monetary policy has been biased toward an expansionary path after 2008. As for the first subperiod, 
countries with high financial vulnerabilities -Hungary (for debt and M2 as threshold variables) and Russia (for growth and M2)- encounter significant difficulties to face external trade shocks in the High regime. For countries with high currency mismatch -Hungary, Russia, and, to a lesser extent, South Korea- alternative threshold variables confirm results from benchmark model: reserve accumulation increases the ability of authorities to respond to external financial shocks. As a consequence, our initial conclusion about the increasing effectiveness of reserves holding between the two subperiods is robust to alternative econometric specifications.

On the whole, our robustness section shed in light the same features as in the benchmark model. Except for the monetary shock over the second subperiod, each model concludes in favor of the benefit to hold foreign exchange reserve to face external shock especially at the impact and medium term for the second sub-period.

\section{Conclusion}

In this paper, we investigated the impact of reserve accumulation on output resilience to external shocks for a sample of 9 emerging markets. Specifically, using a non-linear framework, we assess to what extent reserve holding exhibits diminishing returns as stressed in the literature. Our Threshold VAR models distinguish between two reserve holding regimes qualified Low and High respectively. For all considered external shocks, we find that High forex detention regime tends to increase the resilience of output gap, especially over the second sub-period.

However, considering more closely countries' experiences, we note that the effectiveness of reserves holding is not a general result. Indeed, financial vulnerabilities proxied by currency mismatch exert an influence on the effectiveness of reserve accumulation, especially during the first sub-period. Our econometric methodology does not allow us to investigate the motives of such result. So, it deserves further investigation using a non-linear approach in a panel data framework.

\section{References}

Aizenman, J., Chinn, M.D., Ito, H., 2013. “The “impossible trinity” hypothesis in an era of global imbalances: measurement and testing", Review of International Economics, 21, 447-458.

Aizenman, J., Hutchison, M., 2012. "Exchange market pressure and absorption by international reserves: emerging markets and fear of reserve loss during the 2008-09 crisis", Journal of International Money and Finance, 3, 1076-1091.

Aizenman, J., Ito, H., 2014. "Living with the trilemma constraint: Relative trilemma policy divergence, crises, and output losses for developing countries", Journal of International Money and Finance 49, 28-51.

Aizenman, J., Lee, J., 2007. "International reserves: precautionary versus mercantilist views, theory and evidence", Open Economies Review, 18, 191-214.

Aizenman, J., Sun, Y., 2012. "The financial crisis and sizable international reserves depletion: from 'fear of floating' to the 'fear of losing international reserves'?", International Review of Economics \& Finance, 24, 250-269. 
Alberolaa, E, Erceb, A., Serena, J.M., 2015. "International reserves and gross capital flows dynamics", Journal of International Money and Finance, http://dx.doi.org/doi:10.1016/j.jimonfin.2015.09.003.

Balakrishnan, R., Danninger, S., Elekdag, S., Tytell, I.; 2011. "The Transmission of Financial Stress from Advanced to Emerging Economies", Emerging Markets Finance and Trade, 47, 40-68.

Bergsten, C.F., Gagnon, J.E., 2012. "Currency manipulation, the US economy, and the global economic order", Policy Brief, PB 12-25, Peterson Institute for International Economics.

Berkmen, S.P., Cavallo, 2010. "Exchange rate policies ad liability dollarization: what do the data reveal about causality?", Review of International Economics, 18, 781-795.

Berkmen, S.P., Gelos, G., Rennhack, R., Walsh, J.P., 2012. “The global financial crisis: explaining cross-country differences in the output impact", Journal of International Money and Finance, 31, 42-59.

Blanchard, O.J., Das, M., Faruqee, H., 2010. "The initial impact of the crisis on emerging market countries", Brookings Papers on Economic Activity 41, 263-323.

Bravea, S., Butters, R.A., 2012. "Diagnosing the financial system: financial conditions and financial stress", International Journal of Central Banking, 8, 191-239.

Bussière, M., Cheng, G., Chinn, M.D., Lisack, N., 2015. "For a few dollars more: reserves and growth in times of crises", Journal of International Money and Finance, 52, 127-145.

Cardarelli, R., Elekdag, S., Lall, S., 2008. "Financial stress, downturns, and recoveries", in World Economic Outlook, Chapter 4, International Monetary Fund, Washington D.C., 129-158.

Catão, L.A.V., Milesi-Ferretti, G.M, 2014. "External liabilities and crises", Journal of International Economics, 94, 18-32.

Chow, G.C., Lin, A., 1971. "Best linear unbiased interpolation, distribution, and extrapolation of time series by related series", The Review of Economics and Statistics, 53, 372-375.

Dominguez K.M.E., 2014. "Exchange rate implications of reserve changes: How Non-eurozone European countries fared during the great recession", Comparative Economic Studies, 56, 229252.

Dominguez, K.M.E., Hashimoto, Y, Ito, T., 2012. "International reserves and the global financial crisis", Journal of International Economics, 88, 388-406.

Dooley M.P., Garber P.M., 2005. "Is it 1958 or 1968? Three notes on the longevity of the revived Bretton Woods system”, Brookings Papers on Economic Activity, 63, 147-187.

Dooley, M.P., Folkerts-Landau, D., Garber, P.M., 2014. “The revived Bretton Woods system's first decade", NBER Working Paper, n²0454, September.

Gagnon, J.E., 2013. “Currency wars”, Milken Institute Review, First Quarter, 47-55.

Gallant, RA., Rossi P.E., Tauchen, G., 1993. "Nonlinear dynamic structures”, Econometrica, 61, 871-907.

Hakkio, C.S., Kahn, G.A., 2014. "Evaluating monetary policy at the zero lower bound”, Federal Reserve Bank of Kansas City, Economic Review, Second Quarter, 6-31.

Hakkio, C.S., Keeton, W.R., 2009. "Financial stress: what is it, how can it be measured, and why does it matter?", Federal Reserve Bank of Kansas City, Economic Review, Second Quarter, 550.

Hansen, B. E., 1996. "Inference when a nuisance parameter is not identified under the null hypothesis", Econometrica, 64, 413.430.

Hansen, B. E., 1997. "Inference in TAR models", Studies in Nonlinear Dynamics and Econometrics, 2, 1-24.

Holmes, M.J., Wang P., 2000. "Do monetary shocks exert nonlinear real effects on uk industrial production?", Business Cycle Volatility and Economic Growth Research Paper, No.4, Loughborough: Loughborough University.

Kilian, L., 2009. "Not all oil price shocks are alike: disentangling demand and supply shocks in the crude oil market", American Economic Review, 99, 1053-69. 
Koop, G., Pesaran, M.H., Potter, S.M., 1996. "Impulse response analysis in nonlinear multivariate models", Journal of Econometrics 74, 119.147.

Koop, G.M., 1996. "Parameter uncertainty and impulse response analysis", Journal of Econometrics, 72, 135-149.

Laeven, L., Valencia, F., 2013. "Systemic banking crises database”, IMF Economic Review, 61, 225-270.

Levy-Yeyati, E., Sturzenegger, F., Reggio, I., 2010. "On the endogeneity of exchange rate regimes”, European Economic Review, 54, 659-677.

Llaudes, R., Salman, F., Chivakul, M., 2010. "The impact of the great recession on emerging markets", IMF Working Paper, WP/10/237, October.

Lombardi, M., Zhu, F., 2014. "A shadow policy rate to calibrate US monetary policy at the zero lower bound”, BIS Working Papers, n452, June.

Obstfeld, M., Shambaugh, J.C., Taylor, A.M., 2010. "Financial stability, the trilemma, and international reserves", American Economic Journal: Macroeconomics, 2, 57-94.

Pina, G., 2015. "The recent growth of international reserves in developing economies: a monetary perspective", Journal of International Money and Finance, 58, 172-190.

Rodrik, D., 2006. "The social cost of foreign exchange reserves", International Economic Journal, 20, 253-266.

Sachs, J.D., Tornell, A., Velasco, A., 1996. "Financial crises in emerging markets: the lessons from 1995", Brookings Papers on Economic Activity, 27, 147-198.

Teräsvirta, T., Anderson, H.M., 1992. "Characterizing nonlinearities in business cycles using smooth transition autoregressive models", Journal of Applied Econometrics, 7, 119-136.

Tong, H., 1978. "On a threshold model" in Chun-Hung Chen, ed., Pattern Recognition and Signal Processing, Amsterdam: Sijthoff and Noordhoff, 575-586.

Tong, H., 1983. Threshold models in nonlinear time series analysis, New York, NY: Springer Verlag.

Tong, H., 1990. Non-linear time series: a dynamical system approach, Oxford: Oxford University Press.

Tsay, R.S., 1998. "Testing and modelling multivariate threshold models", Journal of the American Statistical Association, 93, 1188-1202. 


\section{Appendix}

Table 1 Data: definitions and sources

\begin{tabular}{|c|c|c|c|}
\hline Indicators & Definitions & Frequencies & Sources \\
\hline Trade shock & $\begin{array}{l}\text { Index of global real economic } \\
\text { activity in industrial commodity } \\
\text { markets }\end{array}$ & Monthly & $\begin{array}{l}\text { Lutz Kilian, http://www- } \\
\text { personal.umich.edu/ lkilian/reaupdate.txt }\end{array}$ \\
\hline Monetary shock & U.S. shadow policy rate & Monthly & Lombardi and Zhu (2014) \\
\hline Financial shock & U.S. financial stress index & Monthly & Cardarelli et al. (2008), updated database \\
\hline GDP & $\begin{array}{l}\text { Gross domestic product, SA, } \\
100=2010, \text { Brazil, Chile, } \\
\text { Hungary, Mexico, Russia, South } \\
\text { Korea, and Turkey } \\
\text { Gross domestic product, SA, } \\
100=2010 \text {, Indonesia } \\
\text { Gross domestic product, USD } \\
\text { billions }\end{array}$ & $\begin{array}{l}\text { Quarterly } \\
\text { Quarterly } \\
\text { Yearly }\end{array}$ & $\begin{array}{l}\text { IMF International Financial Statistics } \\
\text { OECD, Main Economic Indicators } \\
\text { IMF, World Economic Outlook }\end{array}$ \\
\hline $\begin{array}{l}\text { Industrial / } \\
\text { Manufacturing } \\
\text { production }\end{array}$ & $\begin{array}{l}\text { Brazil, Chile, Hungary, Mexico, } \\
\text { Russia, South Korea, and } \\
\text { Turkey, SA, } 2010=100 \\
\text { Indonesia, Composite Leading } \\
\text { Indicator SA, } \\
\text { Thailand, Leading Economic } \\
\text { Index, SA, } 2000=100\end{array}$ & $\begin{array}{l}\text { Monthly } \\
\text { Monthly } \\
\text { Monthly }\end{array}$ & $\begin{array}{l}\text { IMF International Financial Statistics } \\
\text { OECD, Main Economic Indicators } \\
\text { Bank of Thailand, Datastream }\end{array}$ \\
\hline FOREX & $\begin{array}{l}\begin{array}{l}\text { Foreign exchange reserves, USD } \\
\text { billions }\end{array} \\
\end{array}$ & Monthly & IMF International Financial Statistics \\
\hline
\end{tabular}

Table 2 Crises episodes in each country of the sample

$\begin{array}{lcccc}\text { Country } & \begin{array}{c}\text { Systemic } \\ \text { Banking Crisis } \\ \text { (starting date) }\end{array} & \begin{array}{c}\text { Currency } \\ \text { Crisis (year) }\end{array} & \begin{array}{c}\text { Sovereign } \\ \text { Debt Crisis } \\ \text { (default } \\ \text { date) }\end{array} & \begin{array}{c}\text { Sovereig } \\ \text { Debt } \\ \text { Restructuring } \\ \text { (year) }\end{array} \\ \text { Brazil } & & 1999 & & \\ \text { Chile } & 2008 & 1998 & 1999 & 2002 \\ \text { Hungary } & 1997 & 1998 & & \\ \text { Indonesia } & 1997 & 1995 & & \\ \text { Korea } & 1994 & 1998 & 1998 & 2000 \\ \text { Mexico } & 1998,2008 & 1998 & & \\ \text { Russia } & 1997 & 2001 & & \\ \text { Thailand } & 2000 & & & \\ \text { Turkey } & 2009 & & \end{array}$

Source: Laeven and Valencia (2013) 
Table 3 Nonlinearity test: results

1995-2003

\begin{tabular}{|c|c|c|c|c|c|}
\hline Country & $\begin{array}{l}\text { Threshold } \\
\text { variable }\end{array}$ & $\begin{array}{l}\text { Estimated } \\
\text { threshold }\end{array}$ & & Wald statistic & \\
\hline & & & Sup & Avg & Exp \\
\hline \multirow[t]{3}{*}{ Brazil } & Resgrowth & $\theta=5.8545$ & $141.27(0.00)$ & $89.12(0.00)$ & $67.36(0.00)$ \\
\hline & Resdebt & $\theta=108.83$ & $140.54(0.00)$ & $92.64(0.00)$ & $66.44(0.00)$ \\
\hline & M2 & $\theta=11.0855$ & $135.81(0.00)$ & $93.33(0.00)$ & $64.35(0.00)$ \\
\hline \multirow[t]{3}{*}{ Chile } & Resgrowth & $\theta=19.9707$ & $121.38(0.00)$ & $90.38(0.00)$ & $57.41(0.00)$ \\
\hline & Resdebt & $\theta=155.5198$ & $114.59(0.00)$ & $56.38(0.00)$ & $53.29(0.00)$ \\
\hline & M2 & $\theta=42.9730$ & $99.37(0.00)$ & $71.34(0.00)$ & $46.71(0.00)$ \\
\hline \multirow[t]{3}{*}{ Hungary } & Resgrowth & $\theta=20.1656$ & $102.36(0.00)$ & $66.26(0.00)$ & $47.23(0.00)$ \\
\hline & Resdebt & $\theta=196.7194$ & $103.26(0.00)$ & $78.63(0.00)$ & $48.90(0.00)$ \\
\hline & M2 & $\theta=43.3766$ & $76.33(0.00)$ & $50.61(0.00)$ & $34.66(0.00)$ \\
\hline \multirow[t]{3}{*}{ Indonesia } & Resgrowth & $\theta=15.2889$ & $92.37(0.00)$ & $64.57(0.00)$ & $42.58(0.00)$ \\
\hline & Resdebt & $\theta=128.9607$ & $101.74(0.00)$ & $68.30(0.00)$ & $47.10(0.00)$ \\
\hline & M2 & $\theta=30.1975$ & $91.97(0.00)$ & $69.40(0.00)$ & $42.43(0.00)$ \\
\hline \multirow[t]{3}{*}{ Mexico } & Resgrowth & $\theta=5.3675$ & $80.93(0.00)$ & $55.37(0.00)$ & $36.62(0.00)$ \\
\hline & Resdebt & $\theta=101.9626$ & $70.89(0.00)$ & $48.11(0.00)$ & $32.40(0.00)$ \\
\hline & M2 & $\theta=18.5983$ & $59.39(0.00)$ & $42.83(0.00)$ & $26.98(0.00)$ \\
\hline \multirow[t]{3}{*}{ Russia } & Resgrowth & $\theta=3.77$ & $66.91(0.00)$ & $40.04(0.00)$ & $30.03(0.00)$ \\
\hline & Resdebt & $\theta=62.8416$ & $207.87(0.00)$ & $116.60(0.00)$ & $100.20(0.00)$ \\
\hline & M2 & $\theta=15.1022$ & $85.29(0.00)$ & $48.11(0.00)$ & $39.85(0.00)$ \\
\hline \multirow[t]{3}{*}{ South Korea } & Resgrowth & $\theta=13.8658$ & $157.10(0.00)$ & $110.67(0.00)$ & $74.78(0.00)$ \\
\hline & Resdebt & $\theta=187.7970$ & $160.88(0.00)$ & $119.27(0.00)$ & $76.97(0.00)$ \\
\hline & M2 & $\theta=21.0055$ & $135.16(0.00)$ & $104.66(0.00)$ & $64.40(0.00)$ \\
\hline \multirow[t]{3}{*}{ Thailand } & Resgrowth & $\theta=25.1337$ & $93.74(0.00)$ & $73.58(0.00)$ & $43.24(0.00)$ \\
\hline & Resdebt & $\theta=304.1259$ & $99.78(0.00)$ & $80.12(0.00)$ & $46.66(0.00)$ \\
\hline & M2 & $\theta=24.0849$ & $88.38(0.00)$ & $70.15(0.00)$ & $40.84(0.00)$ \\
\hline \multirow[t]{3}{*}{ Turkey } & Resgrowth & $\theta=9.2564$ & $89.83(0.00)$ & $63.29(0.00)$ & $41.68(0.00)$ \\
\hline & Resdebt & $\theta=97.2117$ & $95.59(0.00)$ & $45.93(0.00)$ & $43.96(0.00)$ \\
\hline & M2 & $\theta=16.7804$ & $84.40(0.00)$ & $52.39(0.00)$ & $39.08(0.00)$ \\
\hline
\end{tabular}

Notes: Corresponding p-values at the 5\% significance level are given in parentheses, Hansen's (1996). Method of inference with 500 replication is applied to find the critical values, sup-Wald: maximum Wald statistic over all possible threshold values, avg-Wald: average Wald statistic over all possible values, exp-Wald: function of the sum of exponential Wald statistics. 
2004-2013

\begin{tabular}{|c|c|c|c|c|c|}
\hline \multirow{3}{*}{$\begin{array}{l}\text { Country } \\
\text { Brazil }\end{array}$} & \multirow{2}{*}{$\begin{array}{l}\text { Threshold } \\
\text { variable }\end{array}$} & $\begin{array}{c}\text { Estimated } \\
\text { threshold }\end{array}$ & \multicolumn{3}{|c|}{ Wald statistic } \\
\hline & & $\theta=11.4788$ & $\begin{array}{l}\text { Sup-Wald } \\
181.74(0.00)\end{array}$ & $\begin{array}{c}\text { avg-Wald } \\
83.97(0.00)\end{array}$ & $\begin{array}{c}\text { exp-Wald } \\
86.95(0.00)\end{array}$ \\
\hline & Resdebt & $\theta=329.8422$ & $271.04(0.00)$ & $102.05(0.00)$ & $131.39(0.00)$ \\
\hline & M2 & $\theta=18.0213$ & $207.62(0.00)$ & $94.76(0.00)$ & $99.74(0.00)$ \\
\hline \multirow[t]{3}{*}{ Chile } & Resgrowth & $\theta=13.1498$ & $122.81(0.00)$ & $92.40(0.00)$ & $58.76(0.00)$ \\
\hline & Resdebt & $\theta=123.3012$ & $170.54(0.00)$ & $110.32(0.00)$ & $81.36(0.00)$ \\
\hline & M2 & $\theta=26.0012$ & $164.60(0.00)$ & $127.80(0.00)$ & $78.40(0.00)$ \\
\hline \multirow[t]{3}{*}{ Hungary } & Resgrowth & $\theta=18.4921$ & $112.38(0.00)$ & $86.31(0.00)$ & $53.52(0.00)$ \\
\hline & Resdebt & $\theta=153.4399$ & $124.29(0.00)$ & $95.07(0.00)$ & $58.56(0.00)$ \\
\hline & M2 & $\theta=50.8295$ & $121.47(0.00)$ & $97.97(0.00)$ & $57.18(0.00)$ \\
\hline \multirow[t]{3}{*}{ Indonesia } & Resgrowth & $\theta=9.9846$ & $116.52(0.00)$ & $93.97(0.00)$ & $54.43(0.00)$ \\
\hline & Resdebt & $\theta=207.6165$ & $96.96(0.00)$ & $78.07(0.00)$ & $45.38(0.00)$ \\
\hline & M2 & $\theta=28.5281$ & $86.11(0.00)$ & $72.22(0.00)$ & $40.32(0.00)$ \\
\hline \multirow{3}{*}{ Mexico } & Resgrowth & $\theta=9.2441$ & $127.16(0.00)$ & $79.00(0.00)$ & $60.60(0.00)$ \\
\hline & Resdebt & $\theta=294.7105$ & $102.07(0.00)$ & $79.92(0.00)$ & $47.87(0.00)$ \\
\hline & M2 & $\theta=32.5443$ & $112.91(0.00)$ & $73.81(0.00)$ & $52.70(0.00)$ \\
\hline \multirow{3}{*}{ Russia } & Resgrowth & $\theta=29.8028$ & $395.63(0.00)$ & $148.73(0.00)$ & $193.69(0.00)$ \\
\hline & Resdebt & $\theta=551.0274$ & $244.63(0.00)$ & $179.00(0.00)$ & $119.01(0.00)$ \\
\hline & M2 & $\theta=46.0357$ & $380.51(0.00)$ & $169.84(0.00)$ & $186.80(0.00)$ \\
\hline \multirow[t]{3}{*}{ South Korea } & Resgrowth & $\theta=22.4738$ & $720.53(0.00)$ & $234.68(0.00)$ & $356.14(0.00)$ \\
\hline & Resdebt & $\theta=208.0581$ & $197.55(0.00)$ & $87.64(0.00)$ & $94.75(0.00)$ \\
\hline & M2 & $\theta=18.1664$ & $337.76(0.00)$ & $108.30(0.00)$ & $164.80(0.00)$ \\
\hline \multirow[t]{3}{*}{ Thailand } & Resgrowth & $\theta=43.4619$ & $162.61(0.00)$ & $102.79(0.00)$ & $77.70(0.00)$ \\
\hline & Resdebt & $\theta=1.0706 \mathrm{e}+003$ & $103.78(0.00)$ & $51.41(0.00)$ & $48.07(0.00)$ \\
\hline & M2 & $\theta=32.1765$ & $108.14(0.00)$ & $70.34(0.00)$ & $50.89(0.00)$ \\
\hline \multirow[t]{3}{*}{ Turkey } & Resgrowth & $\theta=9.6858$ & $528.67(0.00)$ & $182.06(0.00)$ & $260.21(0.00)$ \\
\hline & Resdebt & $\theta=118.6640$ & $396.68(0.00)$ & $119.83(0.00)$ & $194.21(0.00)$ \\
\hline & M2 & $\theta=18.8371$ & $216.40(0.00)$ & $74.73(0.00)$ & $104.23(0.00)$ \\
\hline
\end{tabular}

Notes: Corresponding p-values at the 5\% significance level are given in parentheses, Hansen's (1996).Method of inference with 500 replication is applied to find the critical values, sup-Wald: maximum Wald statistic over all possible threshold values, avg-Wald: average Wald statistic over all possible values, exp-Wald: function of the sum of exponential Wald statistics. 
Table 4 Impulse responses functions with reserves over short term external debt as threshold variable 1995-2003

\begin{tabular}{|c|c|c|c|c|c|c|c|c|c|}
\hline & \multicolumn{3}{|c|}{ Trade shock } & \multicolumn{3}{|c|}{ Monetary shock } & \multicolumn{3}{|c|}{ Financial shock } \\
\hline & Impact & 12 months & 24 months & Impact & 12 months & 24 months & Impact & 12 months & 24 months \\
\hline Brazil & NS & $\mathrm{H}$ & $\mathrm{H}$ & $\mathrm{H}$ & $\mathrm{H}$ & $\mathrm{H}$ & $\mathrm{L}$ & $\mathrm{H}$ & $\mathrm{H}$ \\
\hline Chile & $\mathrm{H}$ & $\mathrm{H}$ & NS & $\mathrm{L}$ & NS & $\mathrm{L}$ & $\mathrm{L}$ & NS & NS \\
\hline Mexico & $\mathrm{H}$ & $\mathrm{H}$ & $\mathrm{H}$ & $\mathrm{H}$ & $\mathrm{H}$ & $\mathrm{H}$ & $\mathrm{H}$ & NS & NS \\
\hline Indonesia & $\mathrm{H}$ & $\mathrm{H}$ & $\mathrm{H}$ & $\mathrm{H}$ & $\mathrm{H}$ & $\mathrm{H}$ & $\mathrm{L}$ & $\mathrm{H}$ & $\mathrm{H}$ \\
\hline South Korea & $\mathrm{L}$ & $\mathrm{H}$ & $\mathrm{H}$ & $\mathrm{H}$ & $\mathrm{H}$ & NS & $\mathrm{H}$ & $\mathrm{L}$ & $\mathrm{L}$ \\
\hline Thailand & $\mathrm{L}$ & $\mathrm{H}$ & $\mathrm{L}$ & $\mathrm{H}$ & $\mathrm{H}$ & $\mathrm{H}$ & $\mathrm{L}$ & $\mathrm{L}$ & $\mathrm{L}$ \\
\hline Hungary & $\mathrm{L}$ & $\mathrm{H}$ & $\mathrm{H}$ & $\mathrm{H}$ & $\mathrm{H}$ & NS & $\mathrm{H}$ & $\mathrm{H}$ & $\mathrm{H}$ \\
\hline Russia & $\mathrm{H}$ & $\mathrm{L}$ & $\mathrm{L}$ & $\mathrm{L}$ & $\mathrm{L}$ & NS & $\mathrm{L}$ & $\mathrm{L}$ & NS \\
\hline Turkey & $\mathrm{H}$ & $\mathrm{H}$ & $\mathrm{H}$ & $\mathrm{H}$ & $\mathrm{H}$ & $\mathrm{H}$ & $\mathrm{H}$ & NS & NS \\
\hline \multicolumn{10}{|l|}{ 2004-2013 } \\
\hline & \multicolumn{3}{|c|}{ Trade shock } & \multicolumn{3}{|c|}{ Monetary shock } & \multicolumn{3}{|c|}{ Financial shock } \\
\hline & Impact & 12 months & 24 months & Impact & 12 months & 24 months & Impact & 12 months & 24 months \\
\hline Brazil & $\mathrm{L}$ & $\mathrm{L}$ & $\mathrm{H}$ & $\mathrm{H}$ & $\mathrm{L}$ & $\mathrm{L}$ & $\mathrm{H}$ & $\mathrm{H}$ & NS \\
\hline Chile & $\mathrm{H}$ & $\mathrm{H}$ & $\mathrm{L}$ & $\mathrm{H}$ & $\mathrm{H}$ & $\mathrm{L}$ & $\mathrm{H}$ & $\mathrm{H}$ & $\mathrm{L}$ \\
\hline Mexico & $\mathrm{H}$ & NS & NS & NS & $\mathrm{L}$ & $\mathrm{L}$ & $\mathrm{L}$ & $\mathrm{L}$ & NS \\
\hline Indonesia & $\mathrm{H}$ & $\mathrm{H}$ & $\mathrm{L}$ & $\mathrm{H}$ & $\mathrm{L}$ & $\mathrm{L}$ & $\mathrm{L}$ & $\mathrm{L}$ & NS \\
\hline South Korea & $\mathrm{H}$ & $\mathrm{H}$ & $\mathrm{L}$ & $\mathrm{L}$ & $\mathrm{L}$ & NS & $\mathrm{H}$ & $\mathrm{L}$ & $\mathrm{L}$ \\
\hline Thailand & $\mathrm{H}$ & $\mathrm{L}$ & $\mathrm{H}$ & $\mathrm{H}$ & $\mathrm{L}$ & $\mathrm{L}$ & $\mathrm{H}$ & $\mathrm{H}$ & $\mathrm{H}$ \\
\hline Hungary & $\mathrm{H}$ & $\mathrm{L}$ & NS & $\mathrm{H}$ & $\mathrm{L}$ & NS & $\mathrm{L}$ & $\mathrm{L}$ & NS \\
\hline Russia & $\mathrm{H}$ & $\mathrm{L}$ & $\mathrm{H}$ & $\mathrm{H}$ & $\mathrm{H}$ & $\mathrm{H}$ & $\mathrm{H}$ & $\mathrm{L}$ & NS \\
\hline Turkey & $\mathrm{L}$ & $\mathrm{L}$ & NS & $\mathrm{H}$ & $\mathrm{L}$ & $\mathrm{H}$ & $\mathrm{H}$ & $\mathrm{H}$ & $\mathrm{L}$ \\
\hline
\end{tabular}


Table 5 Impulse responses functions with reserves over M2 as threshold variable

1995-2003

Trade shock

Monetary shock

Financial shock

Impact 12 months 24 months Impact 12 months 24 months Impact 12 months 24 months

\begin{tabular}{|c|c|c|c|c|c|c|c|c|c|}
\hline Brazil & NS & $\mathrm{L}$ & $\mathrm{H}$ & $\mathrm{L}$ & $\mathrm{H}$ & $\mathrm{L}$ & $\mathrm{H}$ & $\mathrm{H}$ & NS \\
\hline Chile & $\mathrm{L}$ & $\mathrm{L}$ & $\mathrm{L}$ & $\mathrm{H}$ & $\mathrm{H}$ & $\mathrm{H}$ & $\mathrm{L}$ & $\mathrm{H}$ & $\mathrm{H}$ \\
\hline Mexico & $\mathrm{H}$ & $\mathrm{H}$ & $\mathrm{H}$ & $\mathrm{H}$ & $\mathrm{H}$ & $\mathrm{H}$ & $\mathrm{L}$ & $\mathrm{H}$ & $\mathrm{H}$ \\
\hline Indonesia & $\mathrm{L}$ & $\mathrm{H}$ & $\mathrm{L}$ & $\mathrm{H}$ & $\mathrm{H}$ & $\mathrm{H}$ & $\mathrm{H}$ & NS & NS \\
\hline South Korea & $\mathrm{H}$ & $\mathrm{H}$ & $\mathrm{H}$ & $\mathrm{L}$ & $\mathrm{H}$ & NS & $\mathrm{H}$ & NS & NS \\
\hline Thailand & $\mathrm{H}$ & $\mathrm{L}$ & $\mathrm{L}$ & $\mathrm{H}$ & $\mathrm{H}$ & $\mathrm{H}$ & $\mathrm{H}$ & $\mathrm{H}$ & $\mathrm{L}$ \\
\hline Hungary & $\mathrm{H}$ & NS & $\mathrm{H}$ & $\mathrm{H}$ & $\mathrm{H}$ & $\mathrm{NS}$ & $\mathrm{H}$ & $\mathrm{L}$ & $\mathrm{NS}$ \\
\hline Russia & $\mathrm{L}$ & $\mathrm{L}$ & $\mathrm{NS}$ & $\mathrm{H}$ & $\mathrm{L}$ & NS & $\mathrm{L}$ & $\mathrm{L}$ & $\mathrm{NS}$ \\
\hline Turkey & $\mathrm{L}$ & $\mathrm{L}$ & $\mathrm{L}$ & $\mathrm{L}$ & $\mathrm{H}$ & $\mathrm{H}$ & $\mathrm{H}$ & $\mathrm{H}$ & $\mathrm{H}$ \\
\hline
\end{tabular}

2004-2013

Trade shock

Monetary shock

Financial shock

Impact 12 months 24 months Impact 12 months 24 months Impact 12 months 24 months

\begin{tabular}{lccccccccc} 
Brazil & NS & L & L & L & H & L & NS & L & L \\
\hline Chile & H & L & L & H & H & NS & H & H & NS \\
\hline Mexico & L & L & NS & H & NS & NS & L & H & NS \\
\hline Indonesia & L & H & L & NS & L & H & L & H & H \\
\hline South Korea & H & L & NS & L & L & NS & H & H & NS \\
\hline Thailand & H & H & NS & NS & L & H & H & H & H \\
\hline Hungary & H & L & NS & H & H & L & H & H & H \\
\hline Russia & H & L & L & NS & L & H & NS & H & H \\
\hline Turkey & L & L & L & H & H & H & H & H & H
\end{tabular}


Figure 1 Foreign exchange reserves, in USD billions

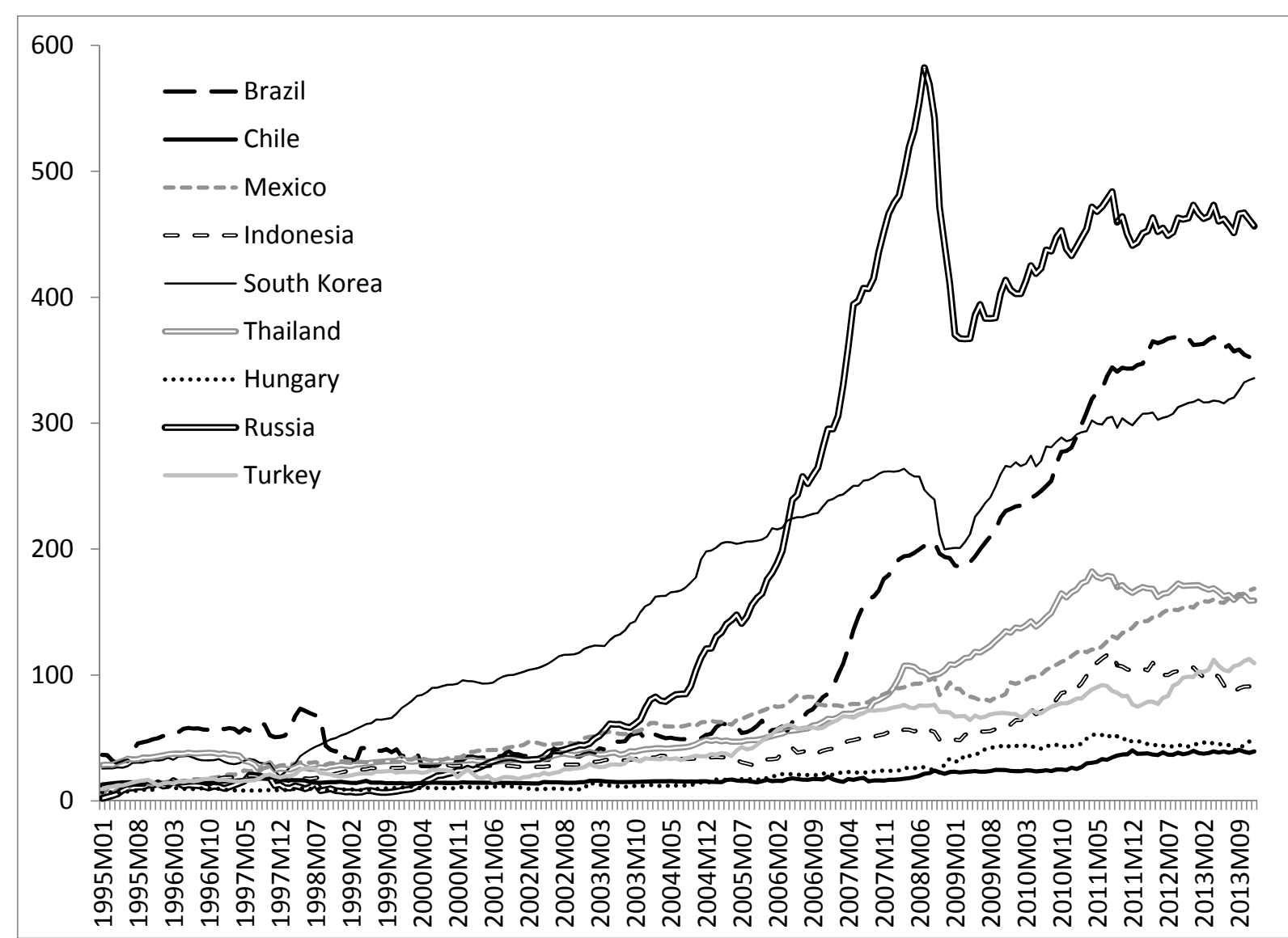

Source: IMF, International Financial Statistics Database 
Figure 2a Output gap over the period 1995-M1 - 2003M12

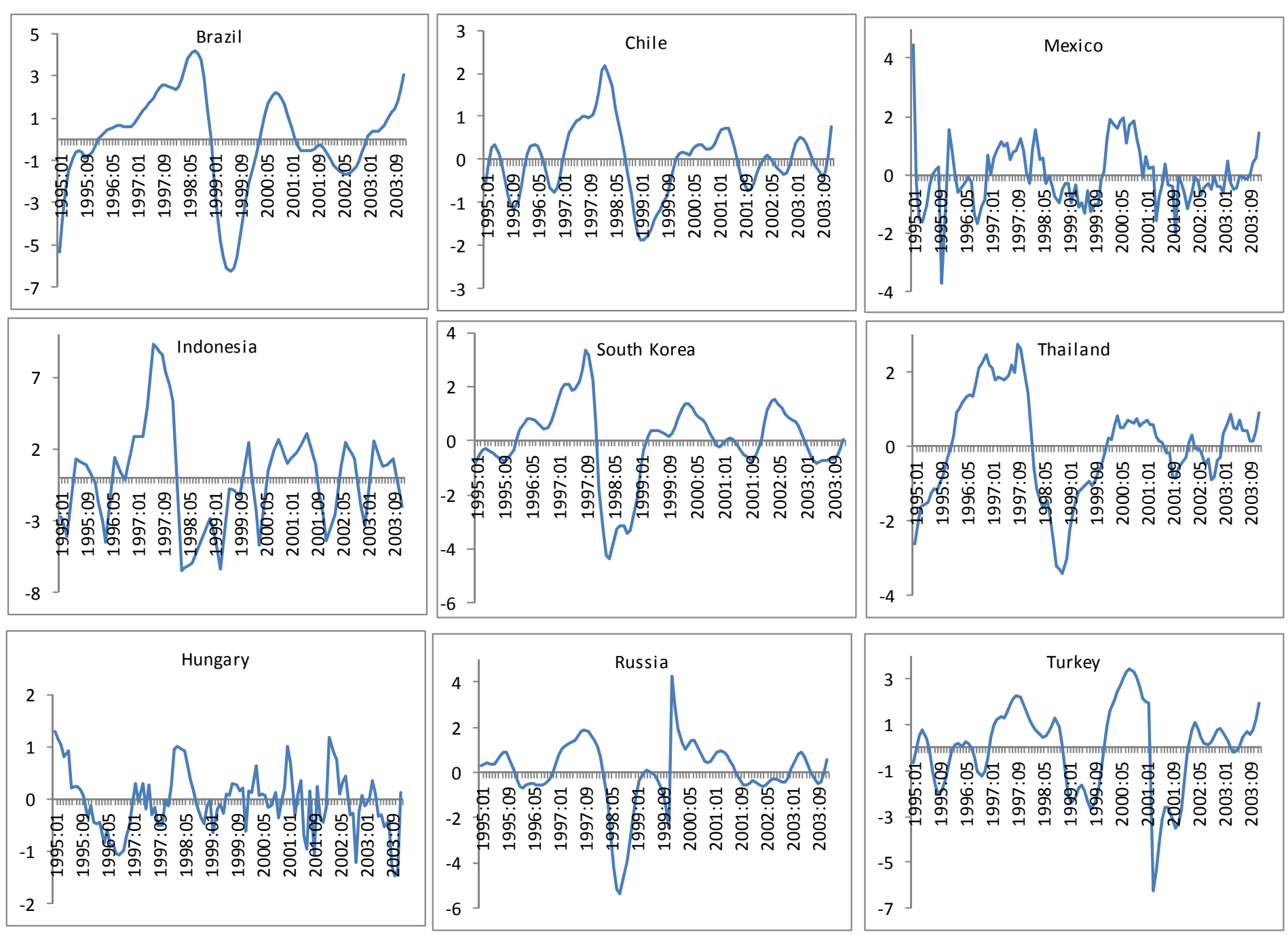

Source: authors 
Figure 2b Output gap over the period 2004-M1 - 2013M12

\begin{tabular}{|c|c|c|}
\hline $\begin{array}{c}10 \\
5 \\
-10\end{array}$ & 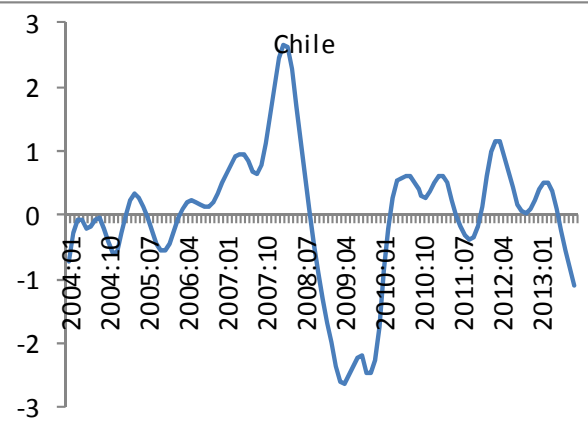 & 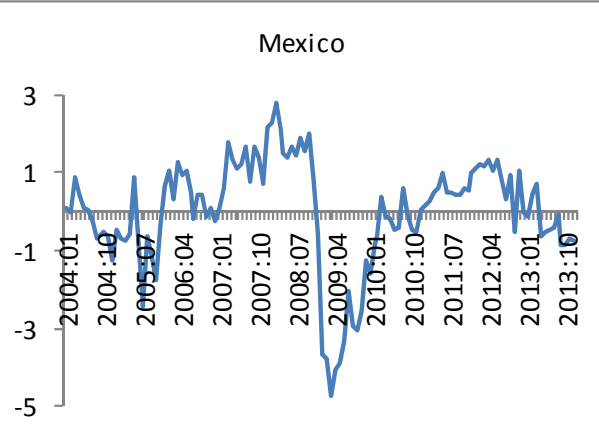 \\
\hline 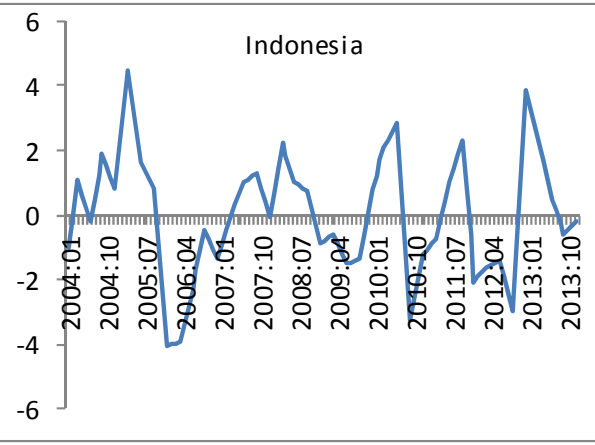 & 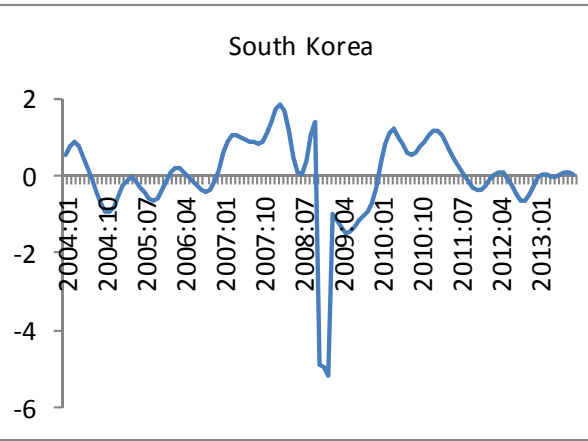 & 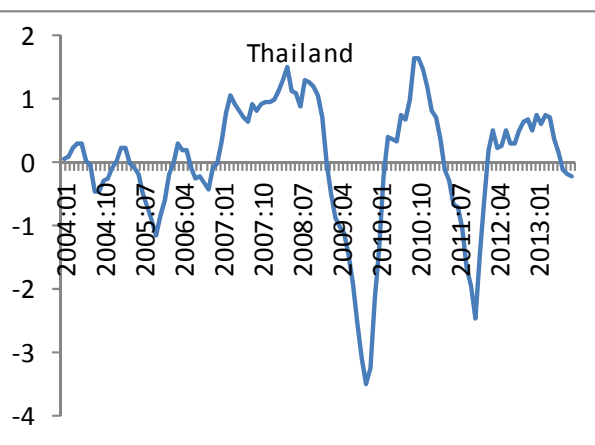 \\
\hline  & 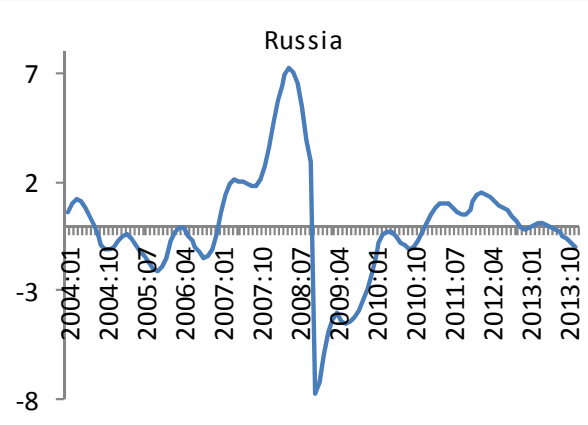 &  \\
\hline
\end{tabular}


Figure 3 External shocks 1995M1-2003M12 and 2004M1-2013M12

2a. Trade shodks, 1995M1-2003M12

2b. Trade shodks, 2004M1-2013M12

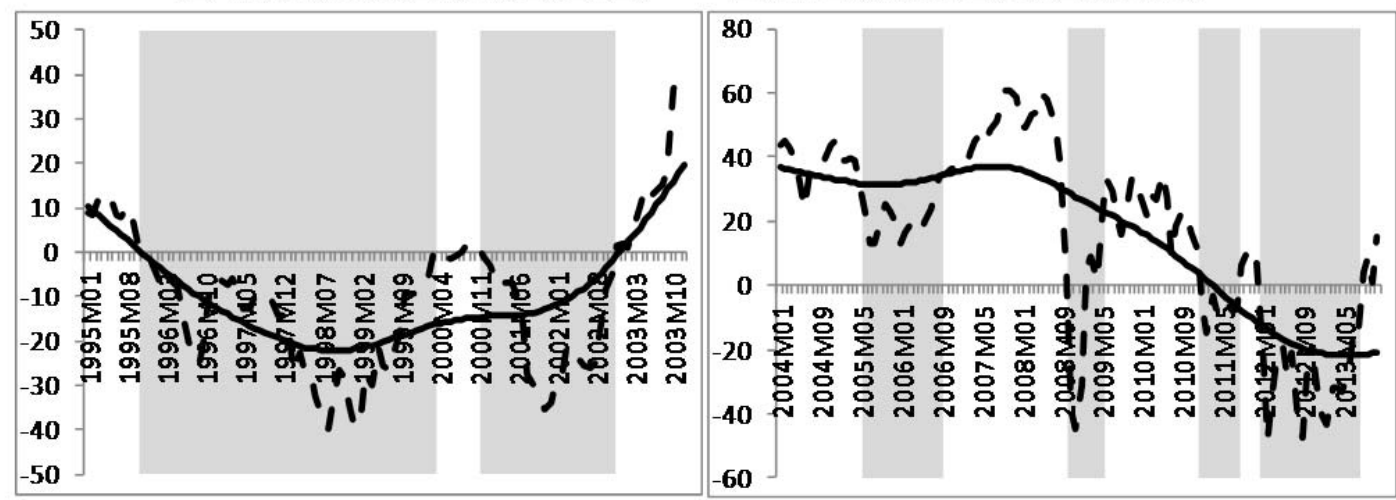

$\begin{array}{ll}- & \text { HP trend } \\ --\cdot & \text { Index of global real economic activity in industrial }\end{array}$ commodity markets

2c. Monetary shocks, 1995M1-2003M12

2d. Monetary shocks, 2004M1-2013M12

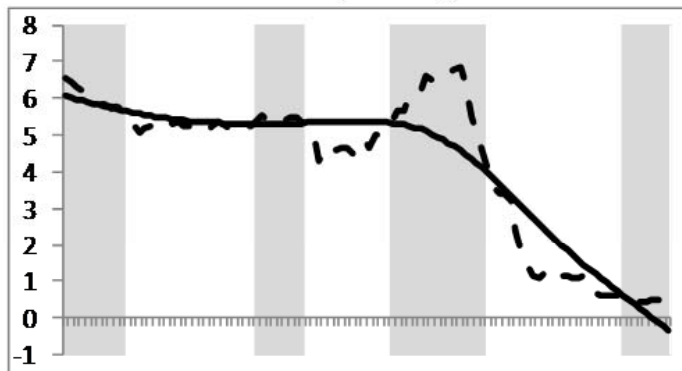

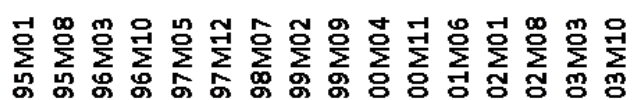
冬先

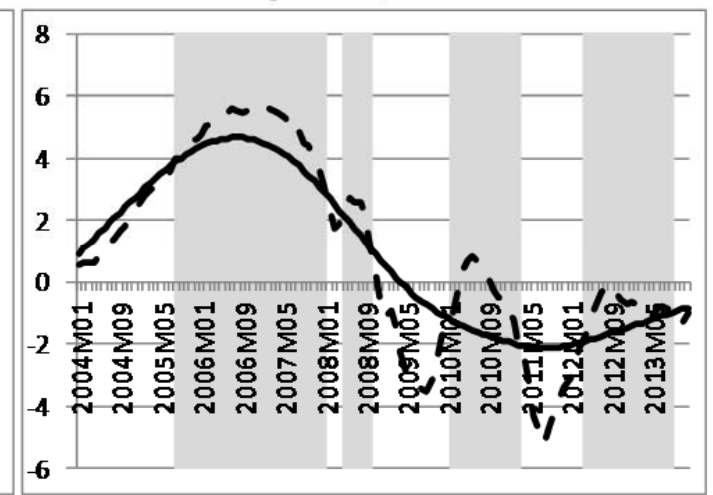

$\begin{array}{ll}- \text { HP trend } \\ --\cdot & \text { Shadow policy rate }\end{array}$

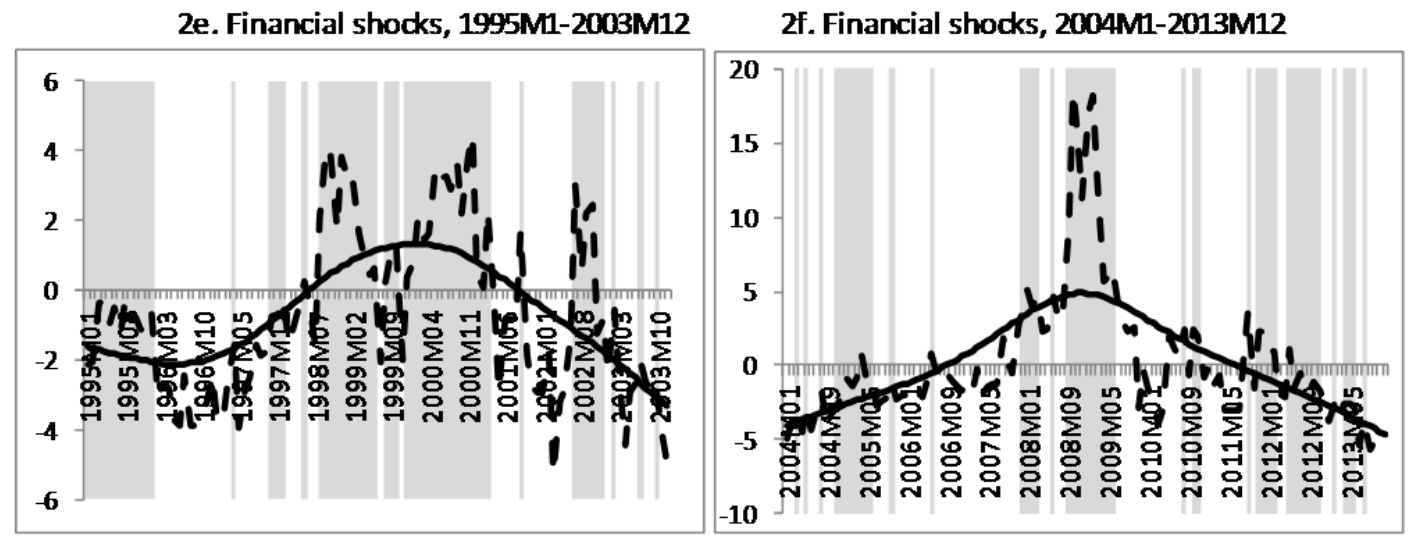

HP trend

- - Financial stress index 
Figure 4 Ratio of foreign liabilities in the domestic financial sector relative to money stocks



Source: authors' estimates, IMF, International Financial Statistics Database 
Figure 5a Impulse responses functions to external shocks. 1995M1-2003m12
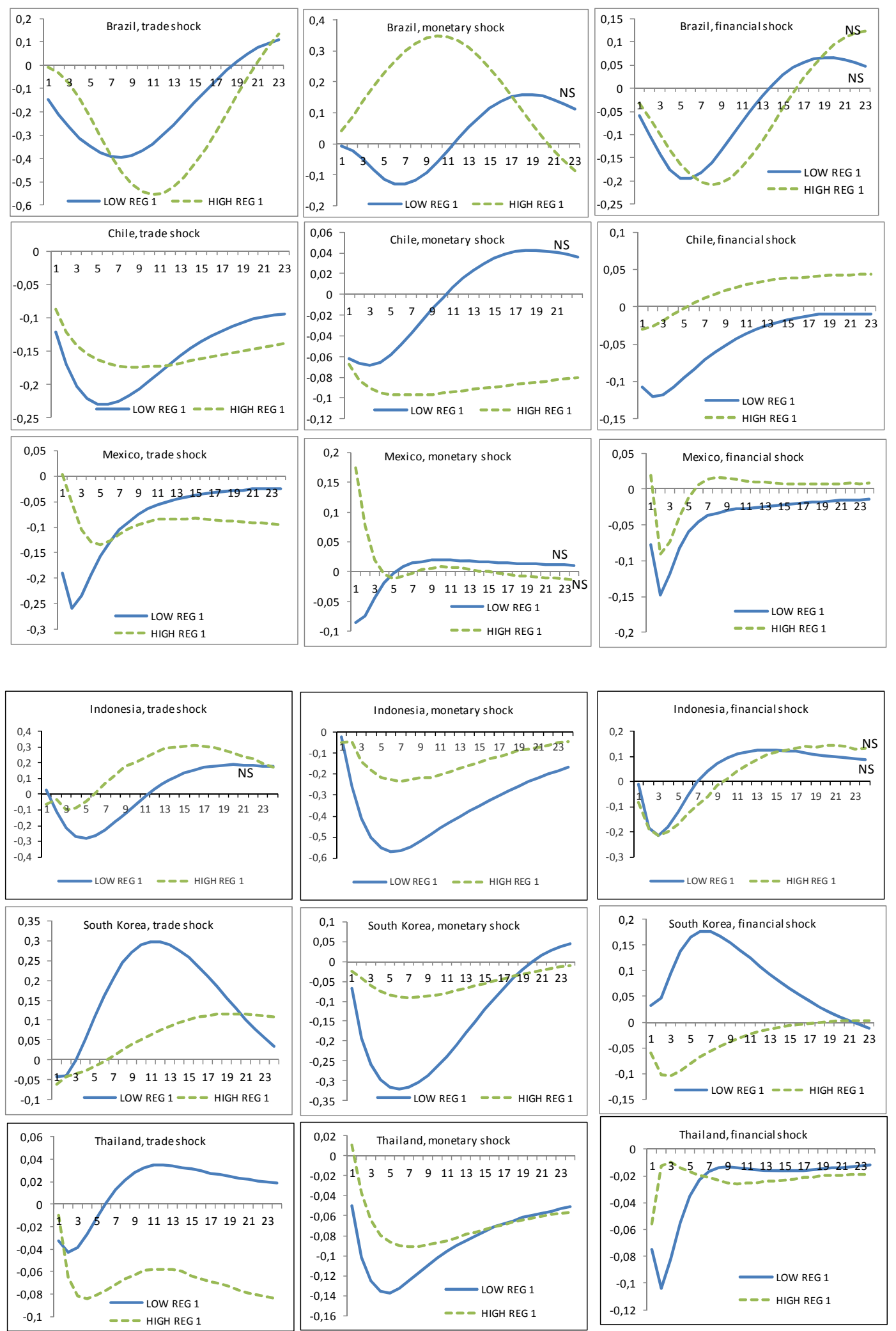

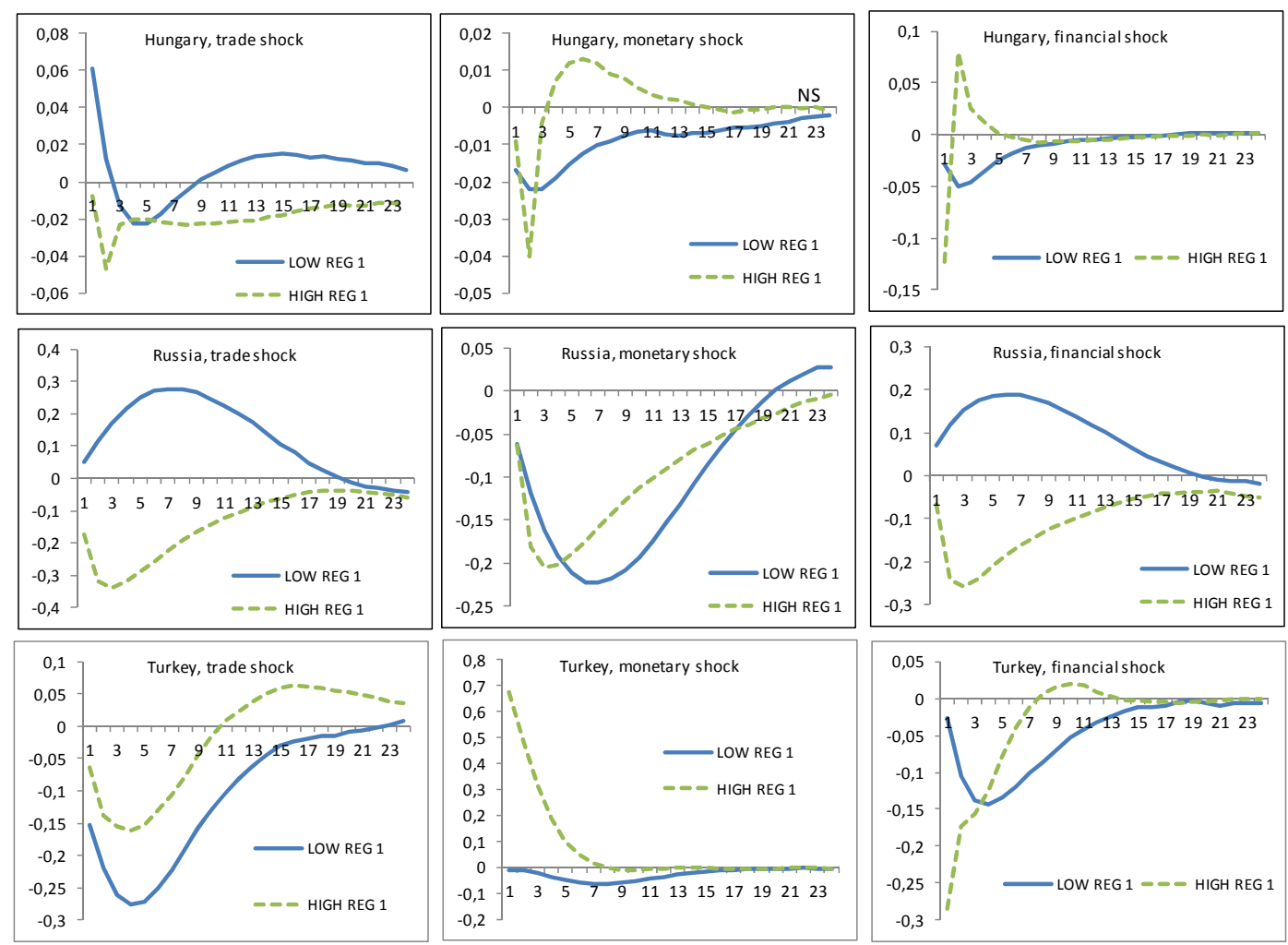

Figure 5b Impulse responses functions to external shocks. 2004M1-2013m12
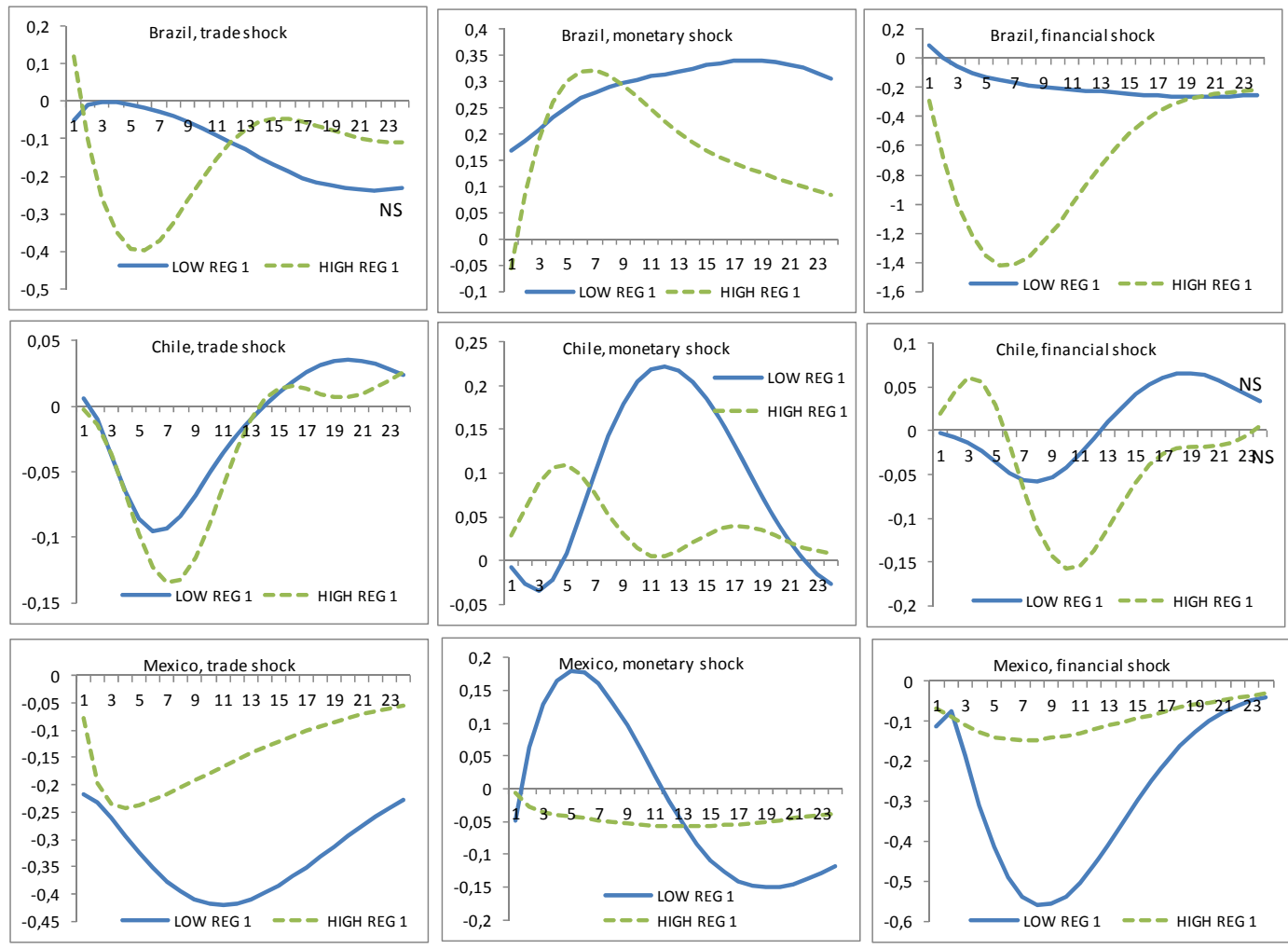

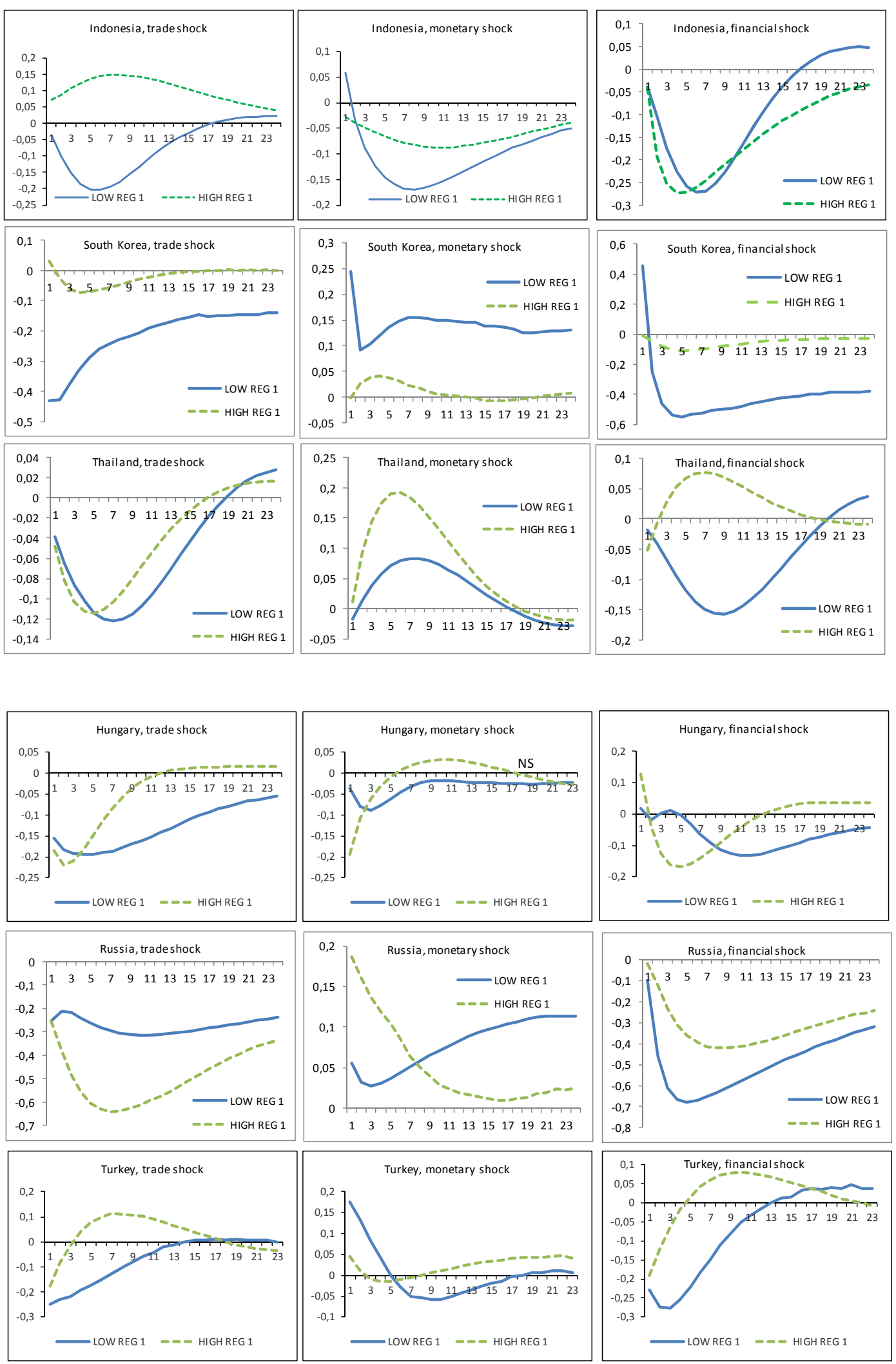
Figures 6 Generalized impulse responses functions

Dotted lines: confidence intervals

6a. Reserves over GDP ratio 1995M1-2003M12
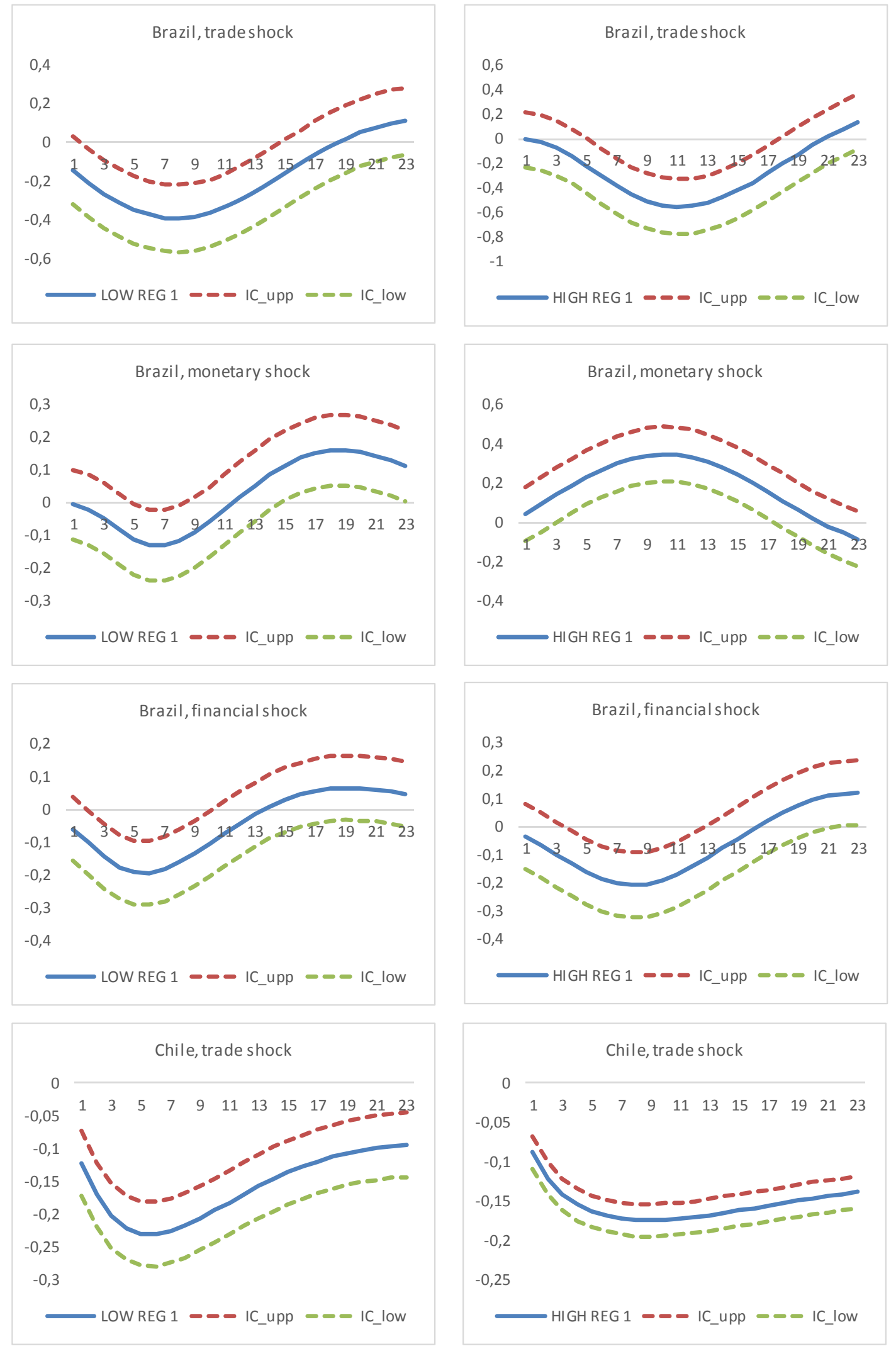

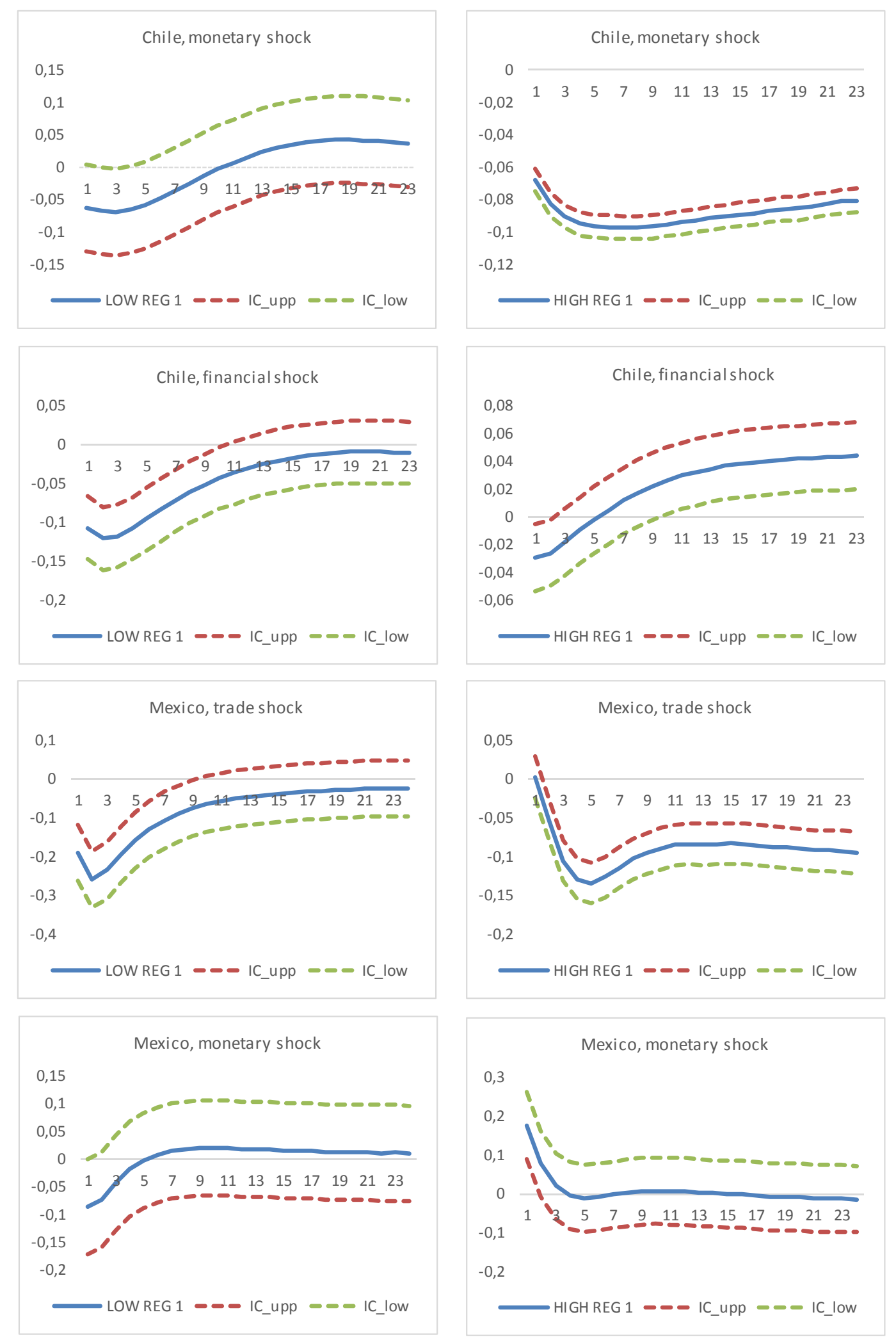

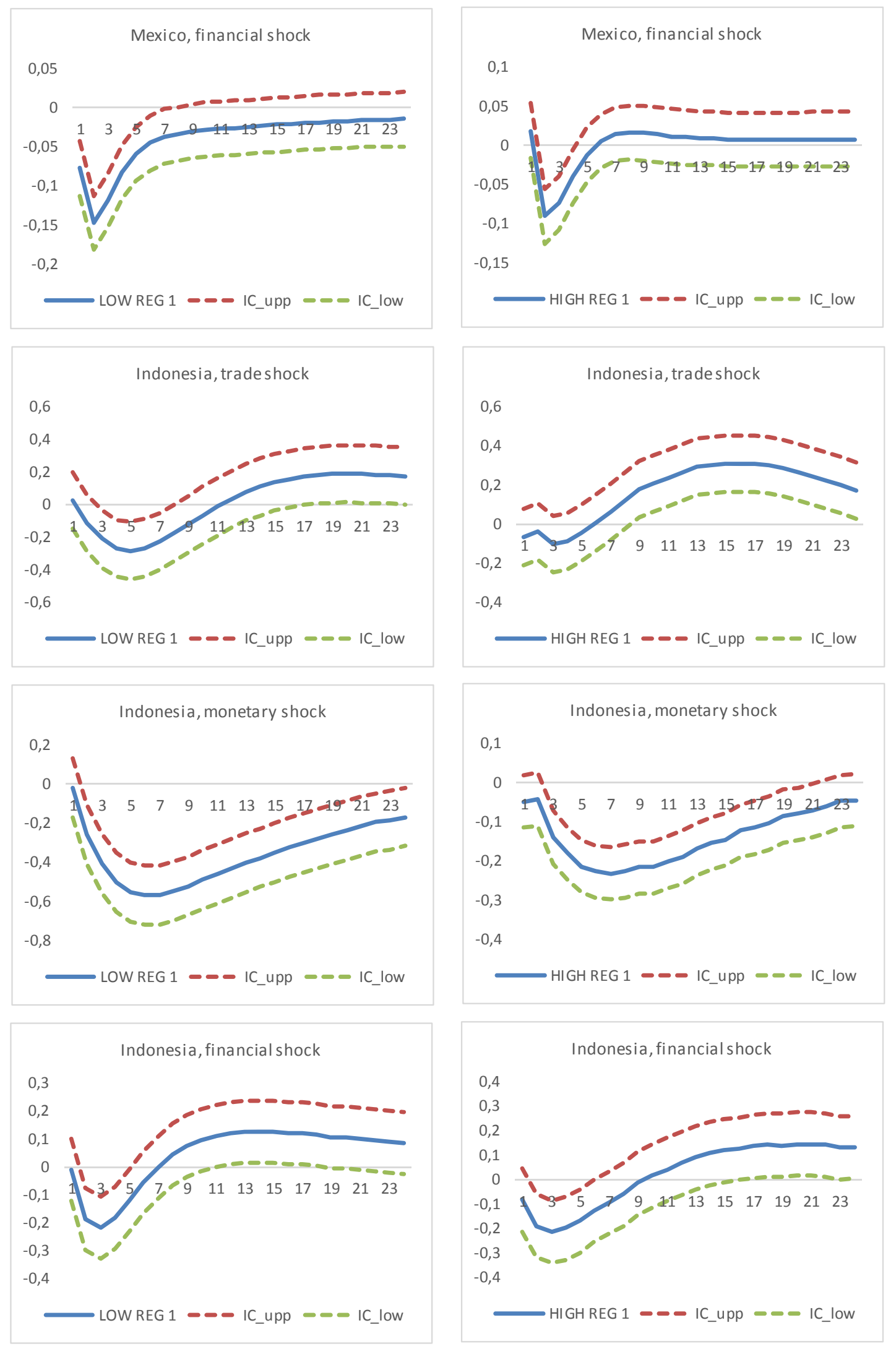

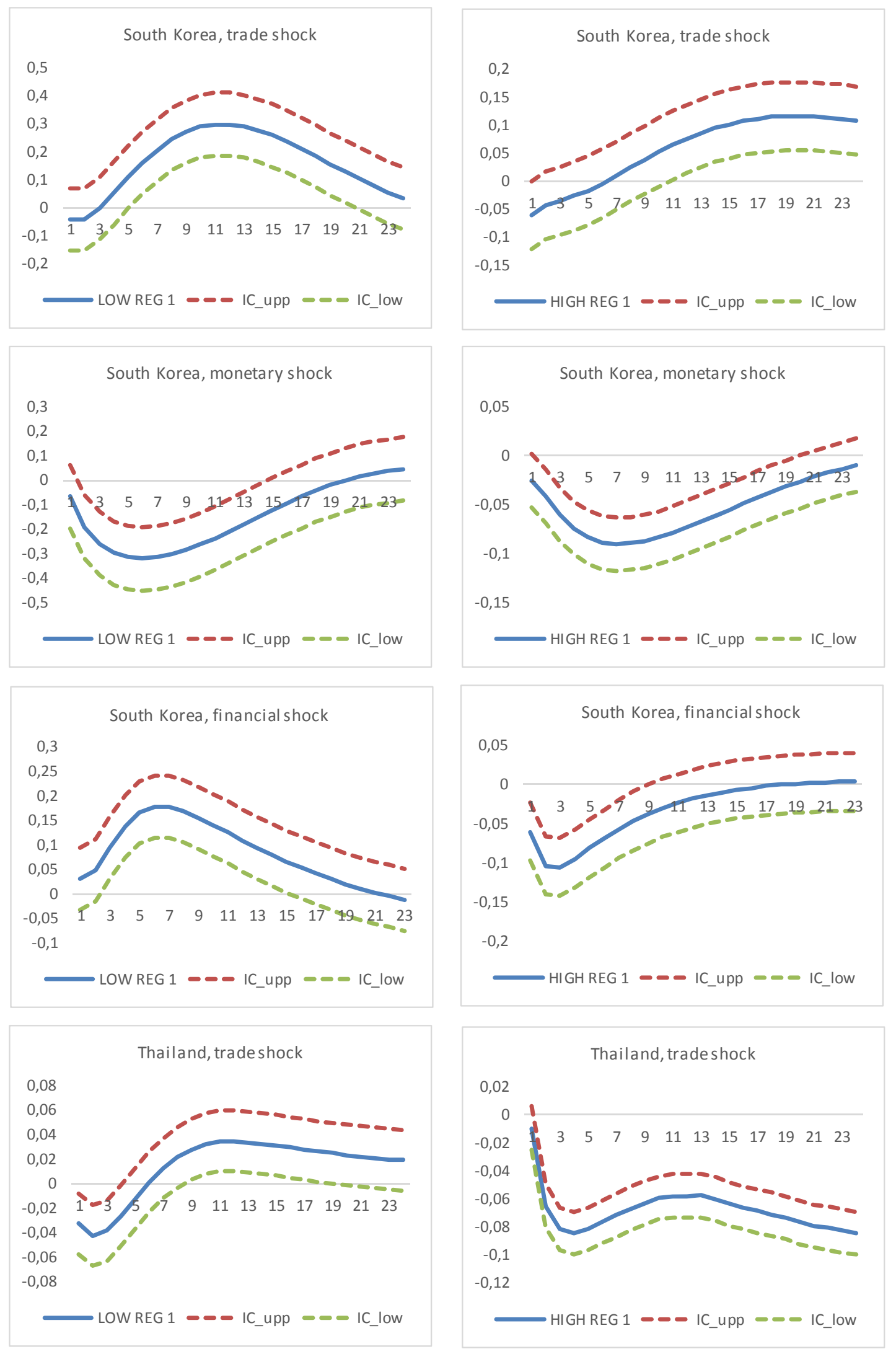

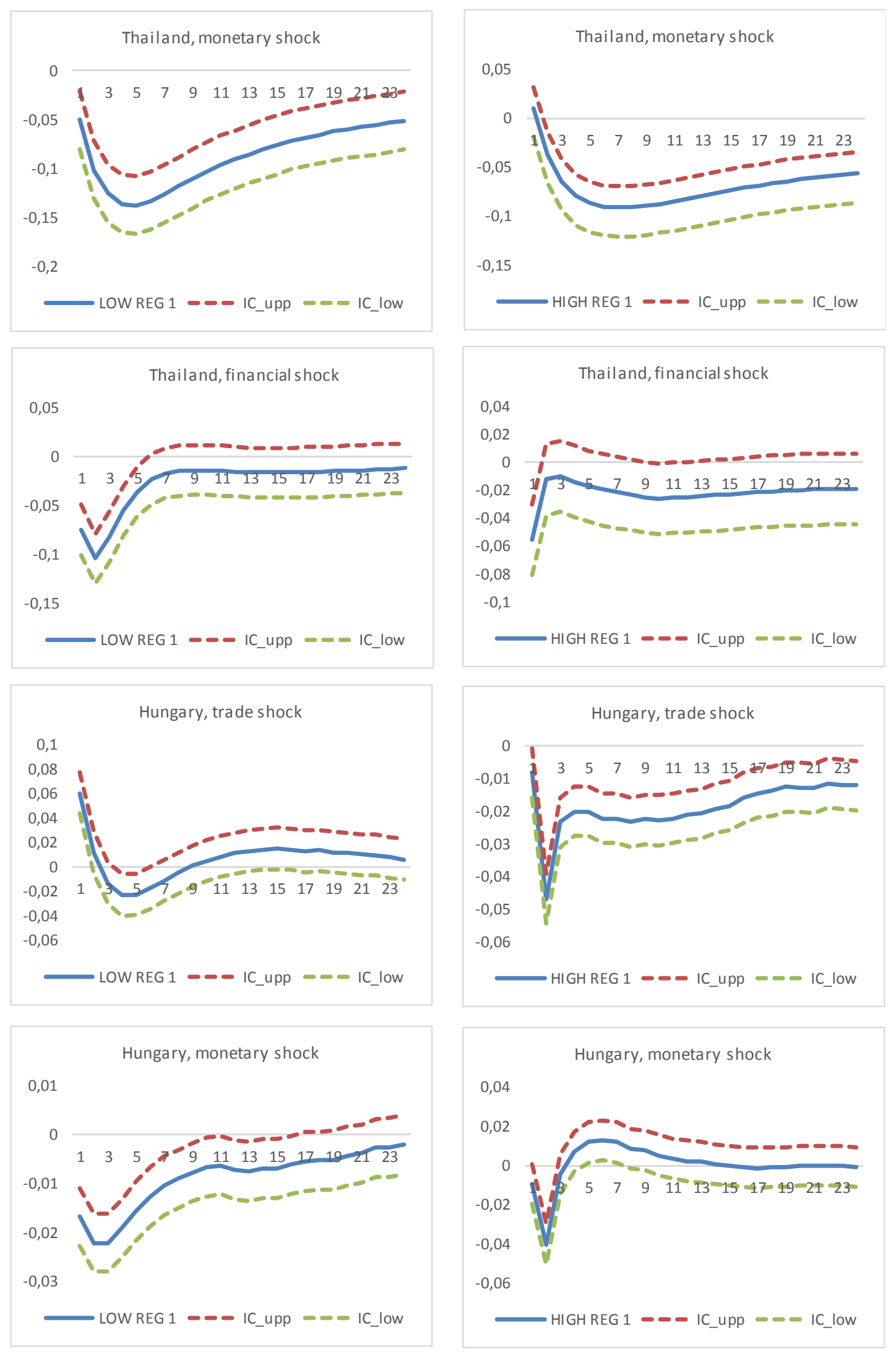

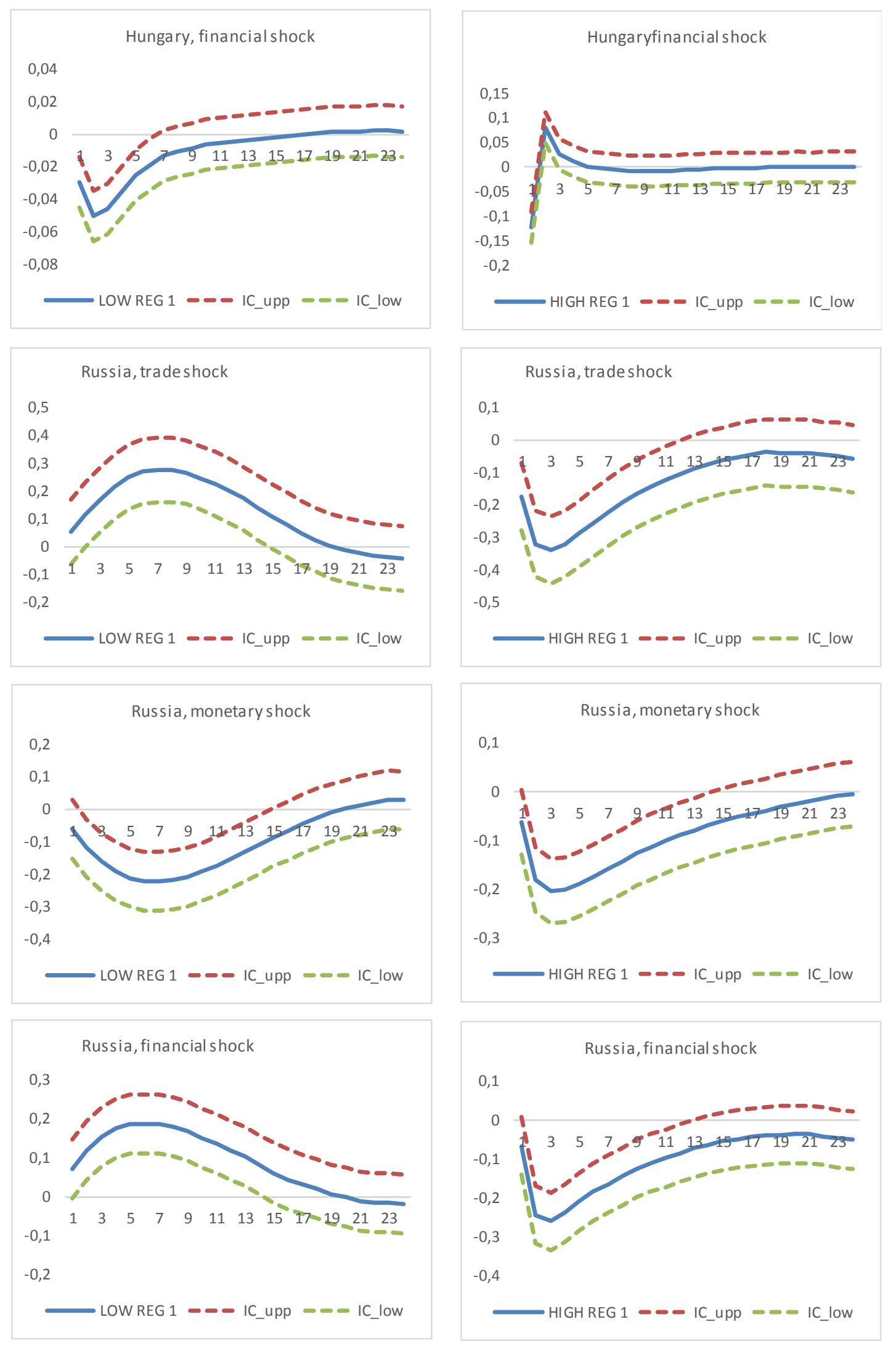

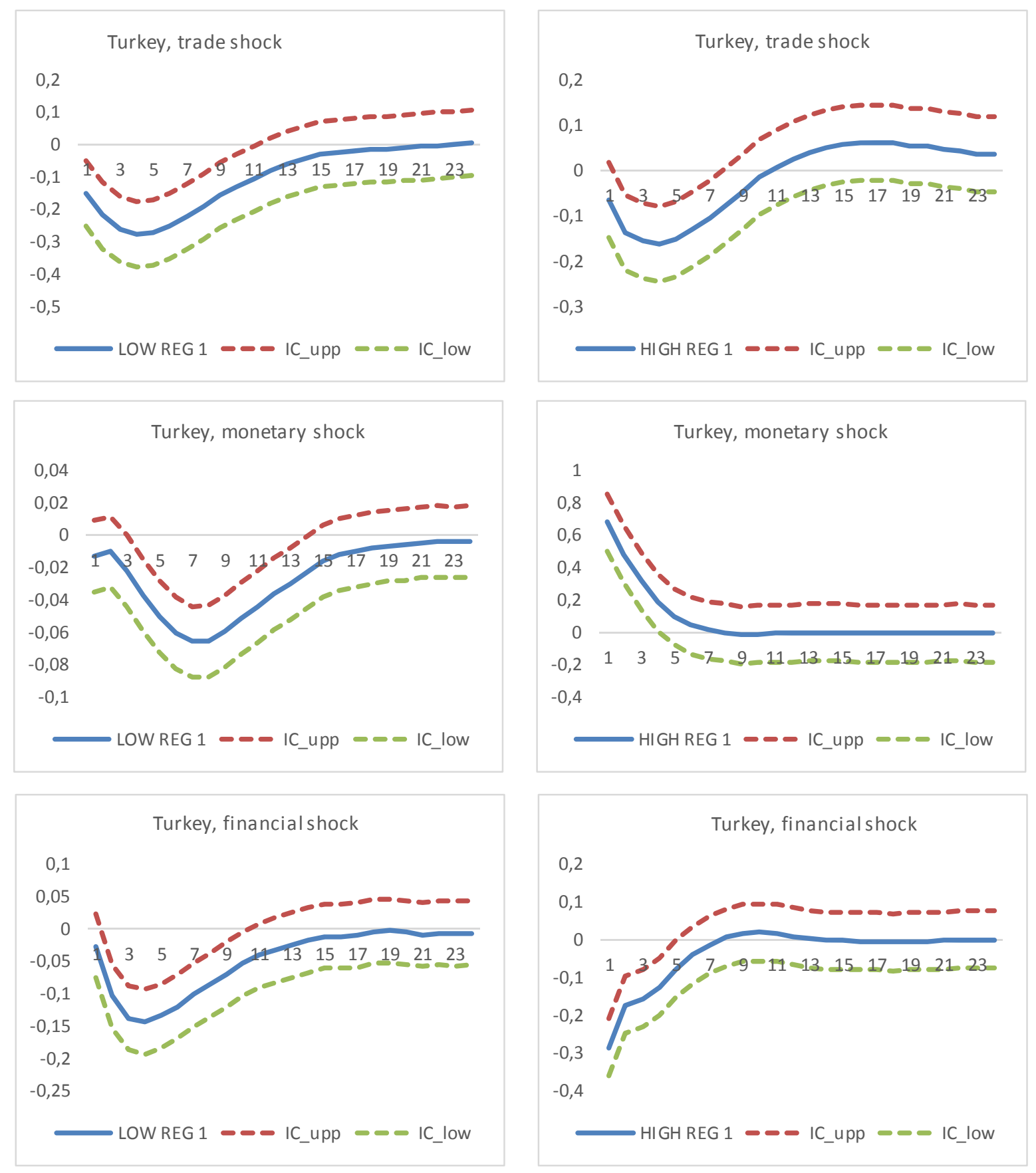
6b. Reserves over GDP ratio 2004M1-2013M12
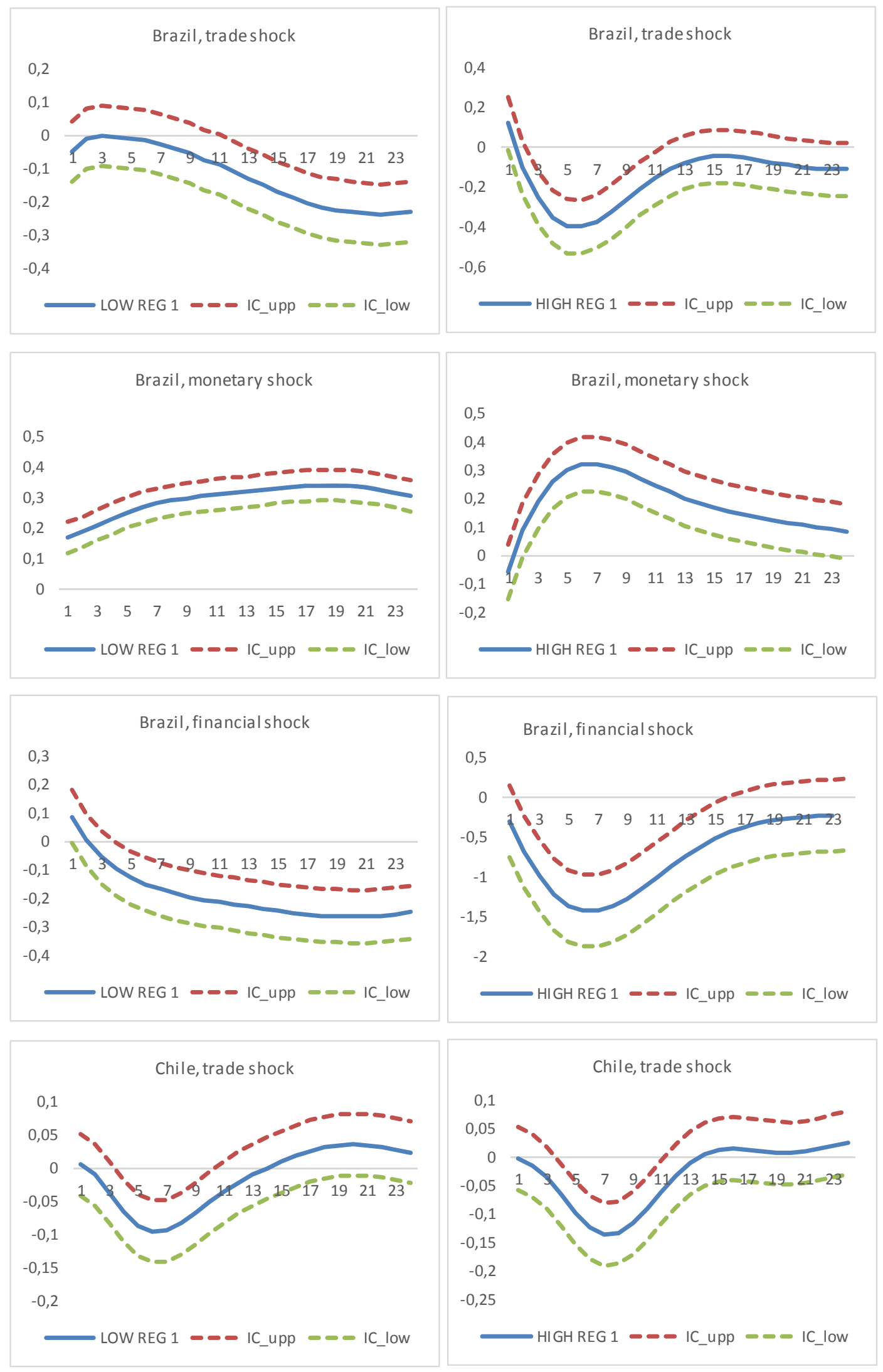

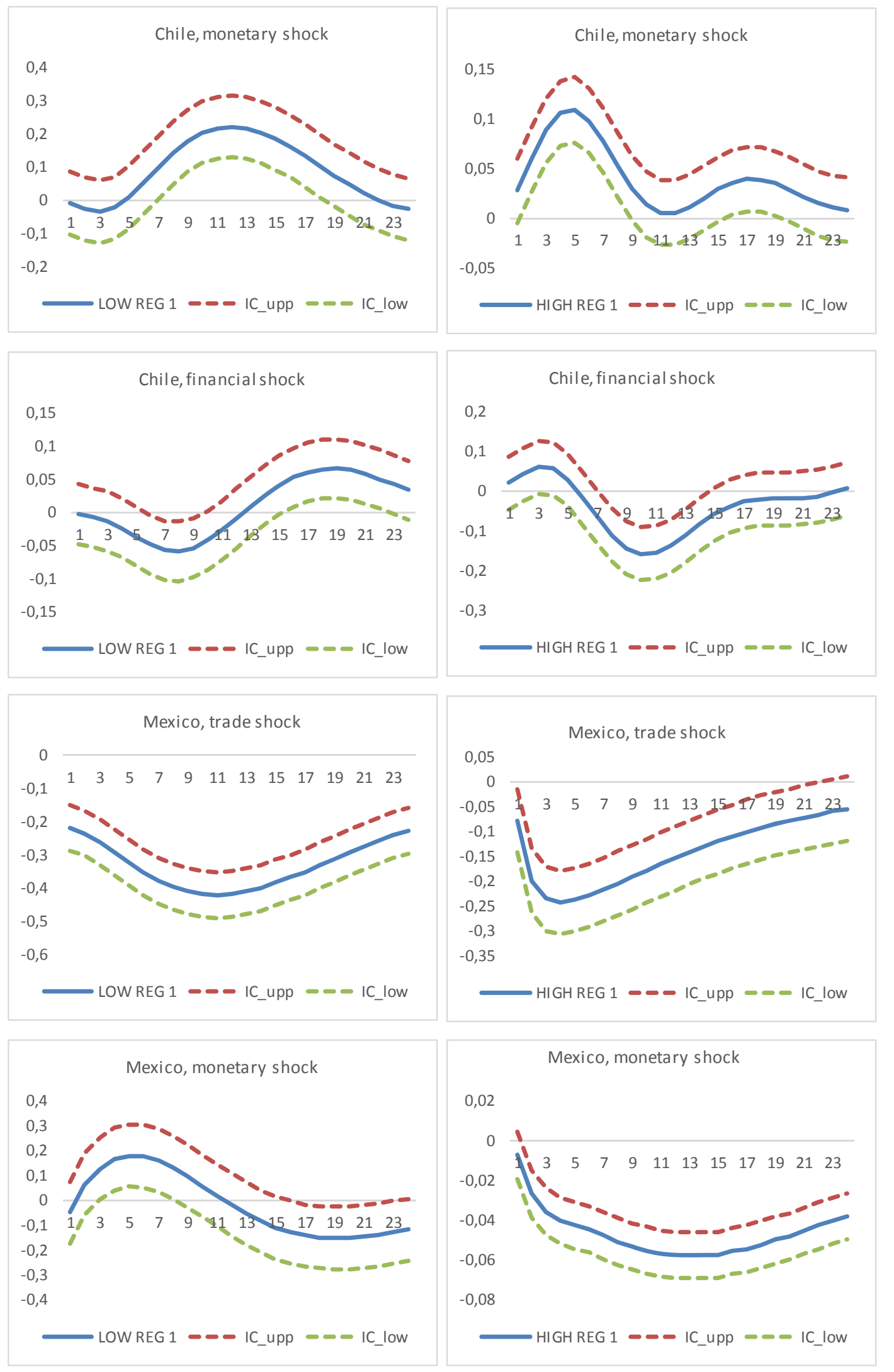

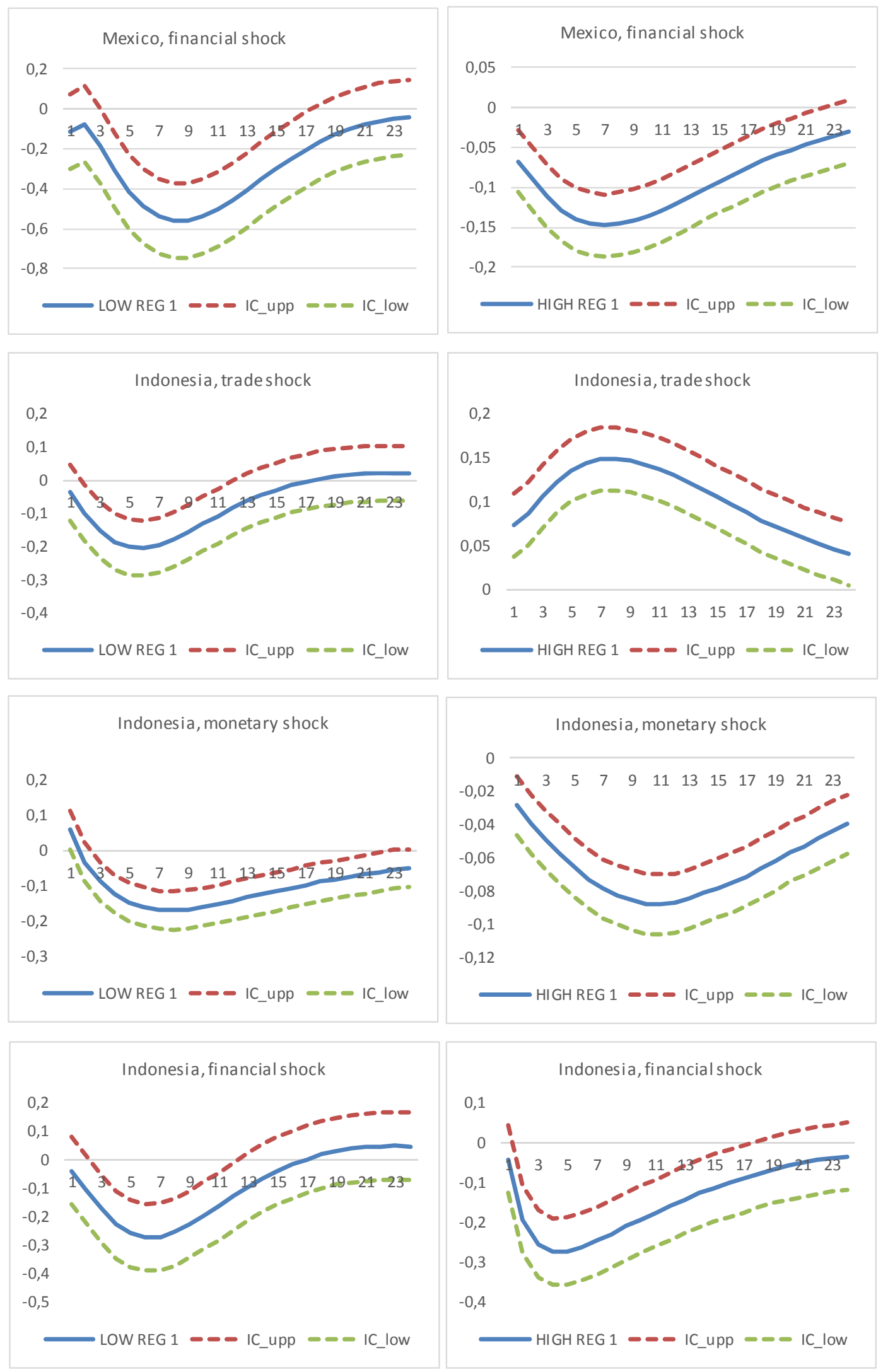

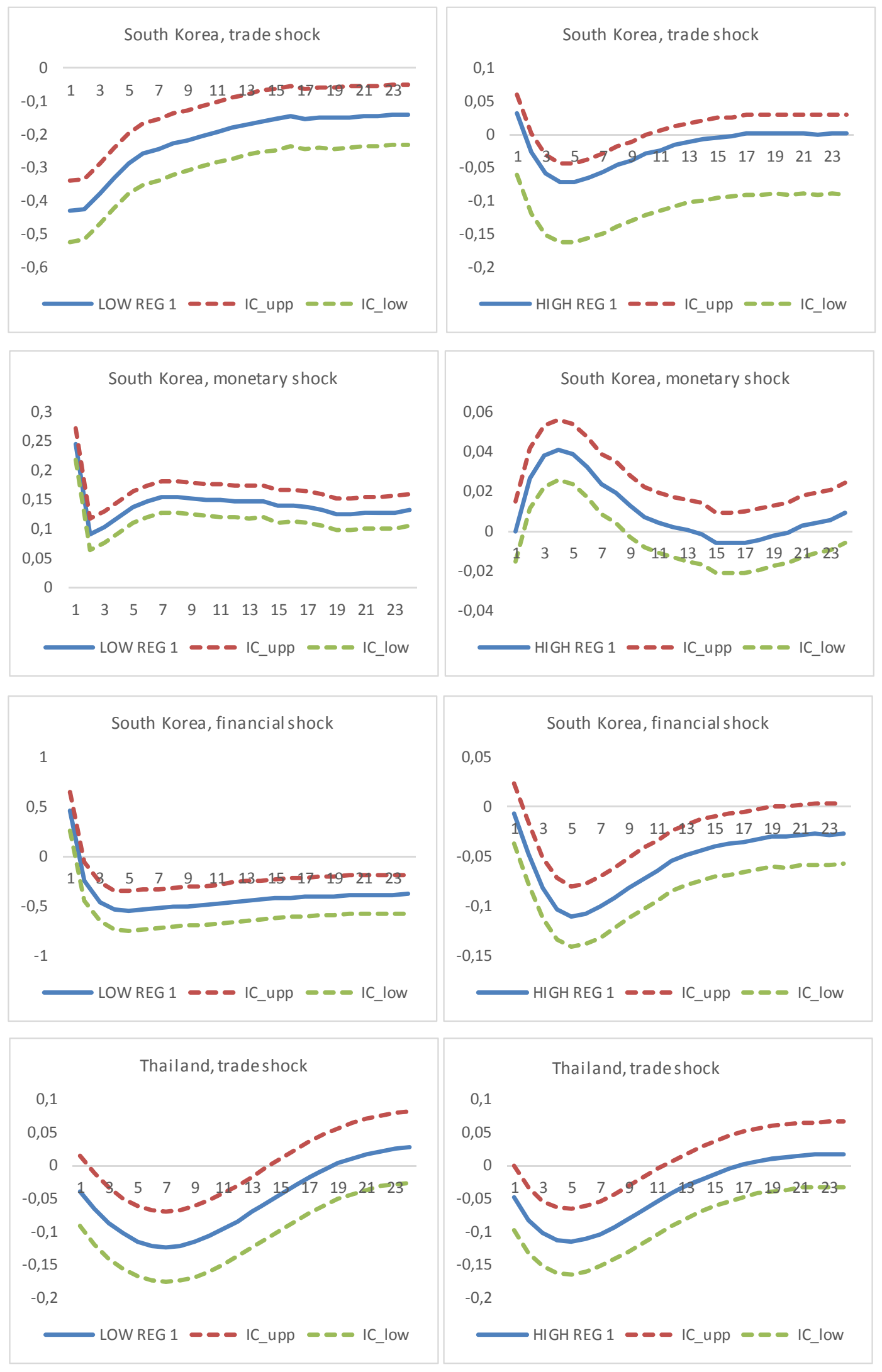

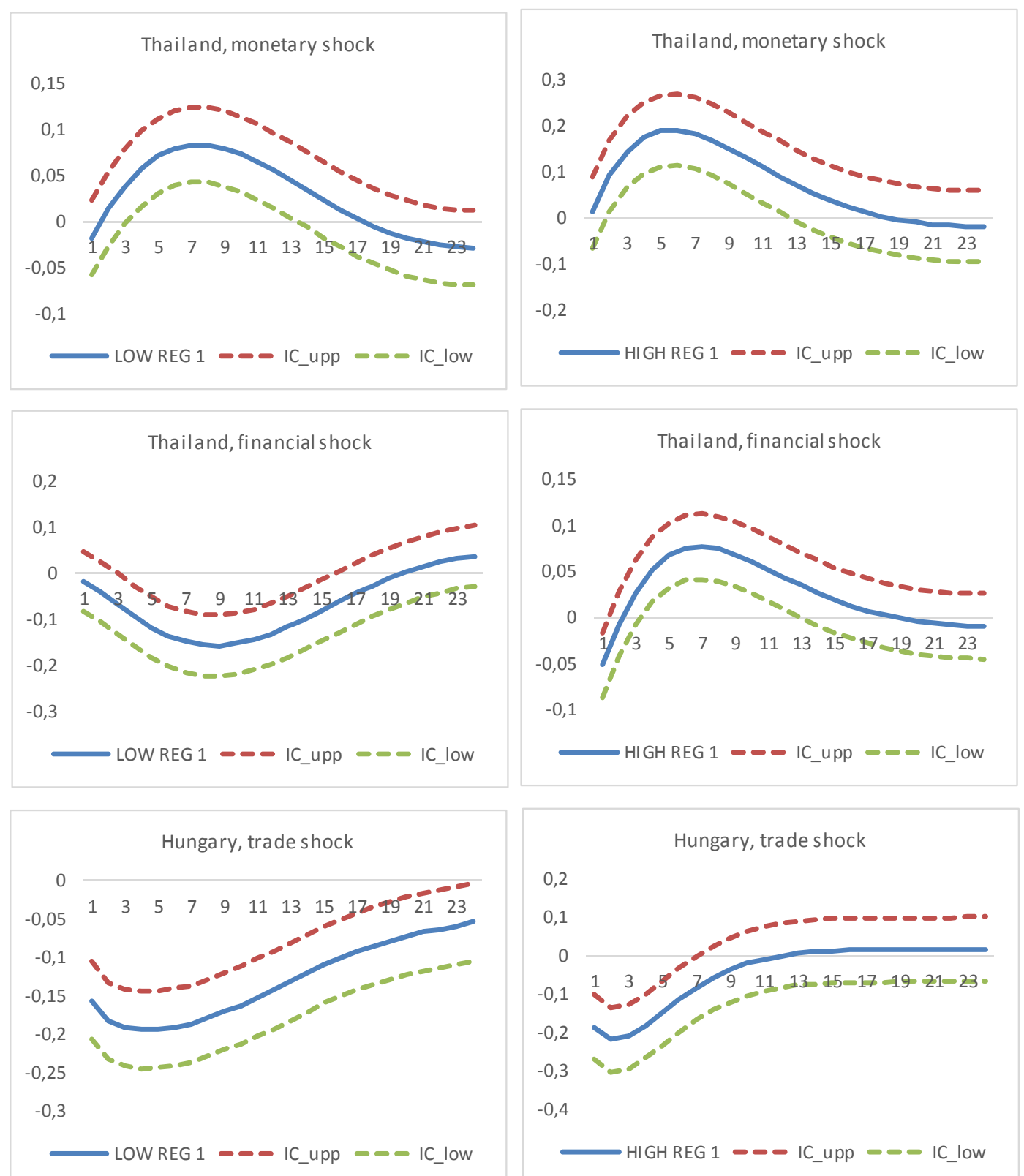
$-0,1$
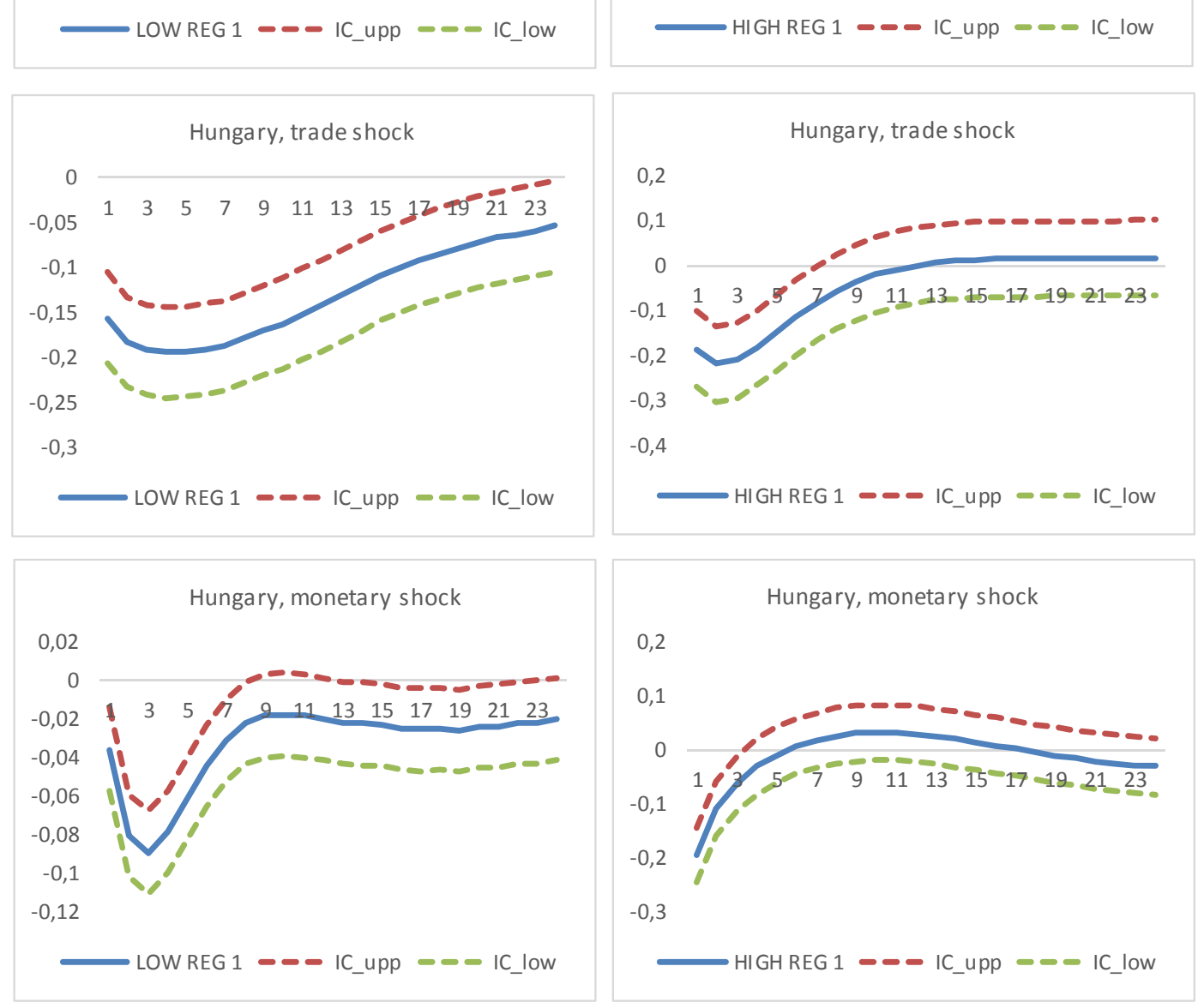

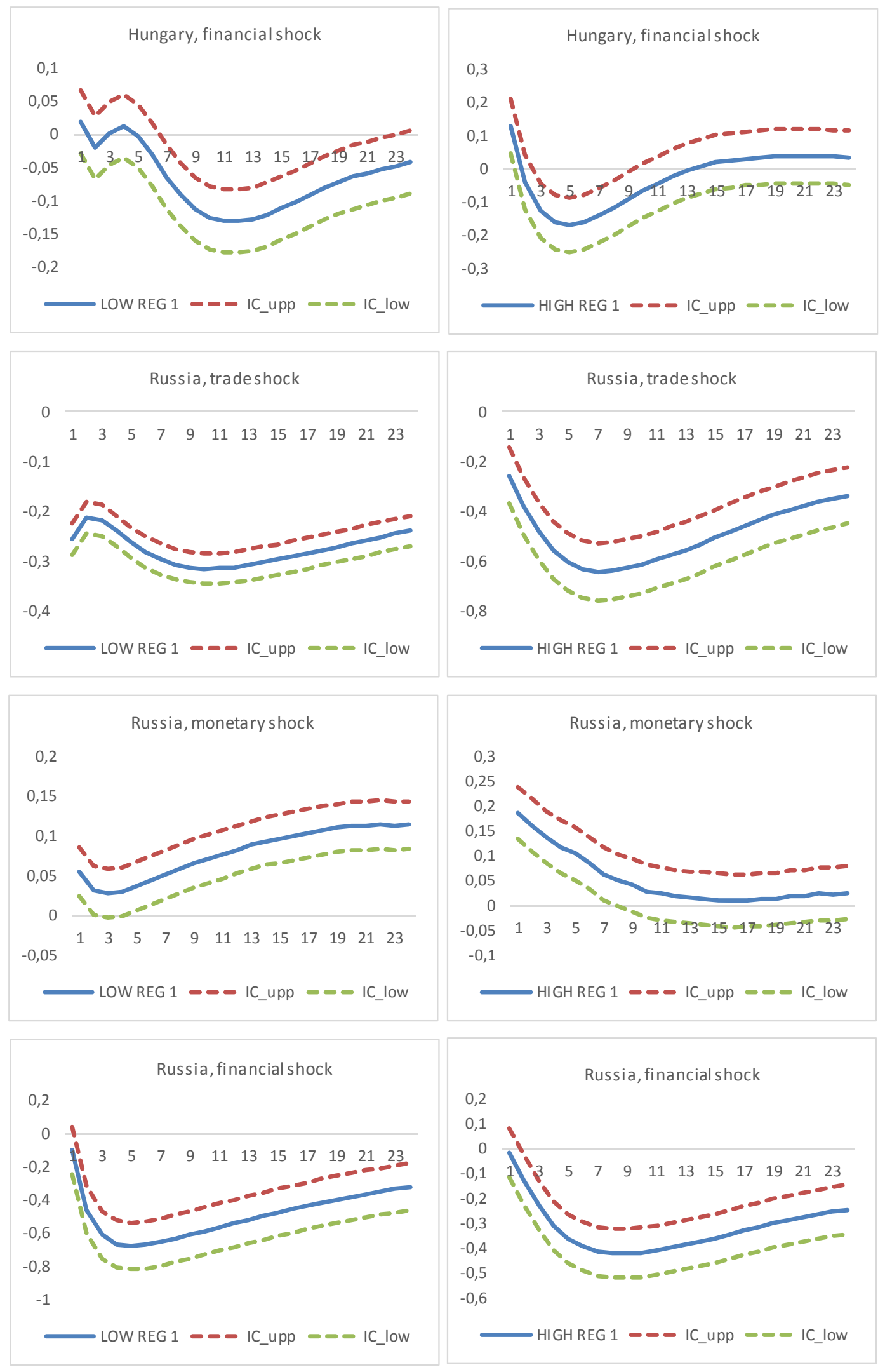

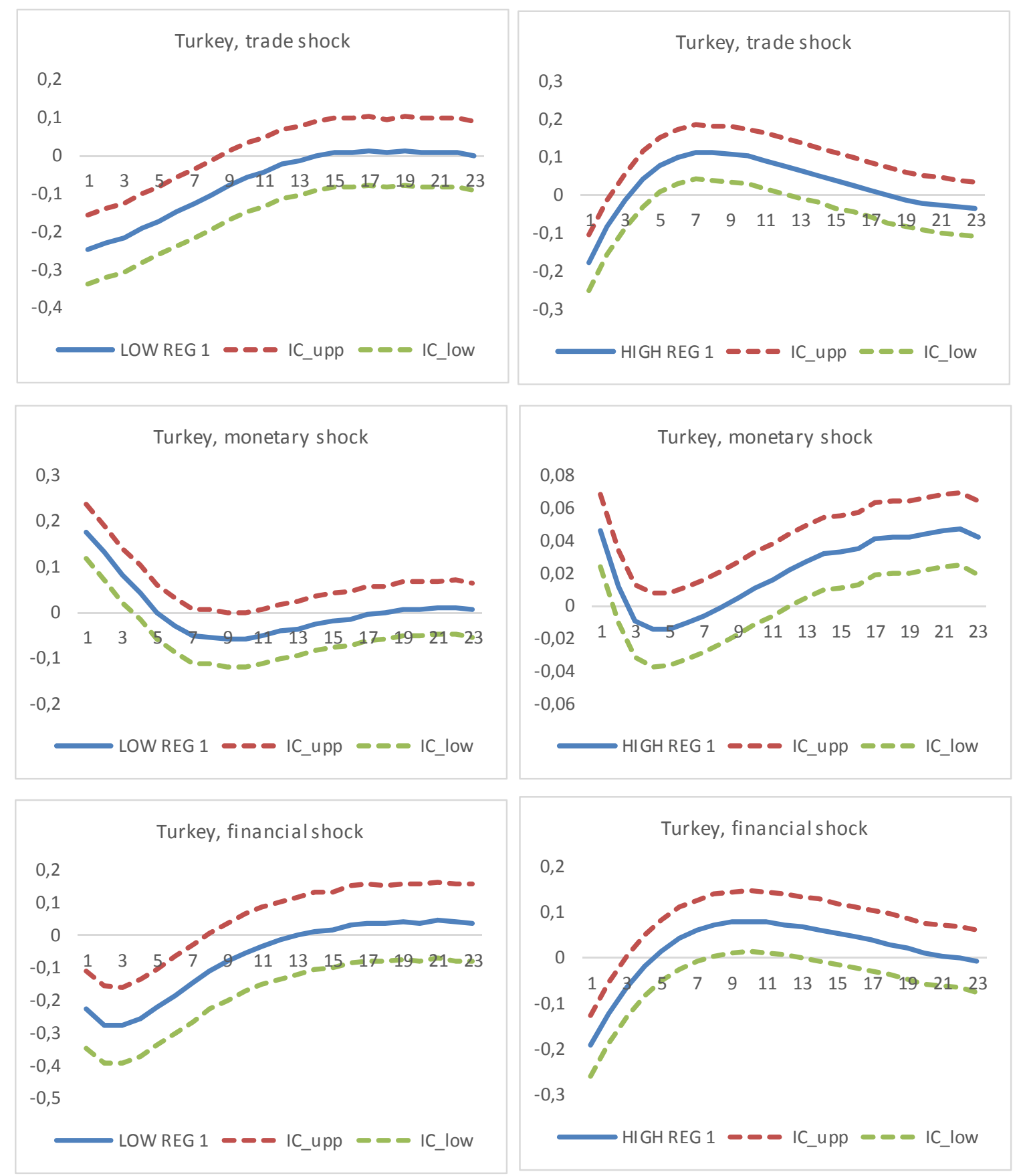
6c. Reserves over short-term external debt ratio 1995M1-2003M12
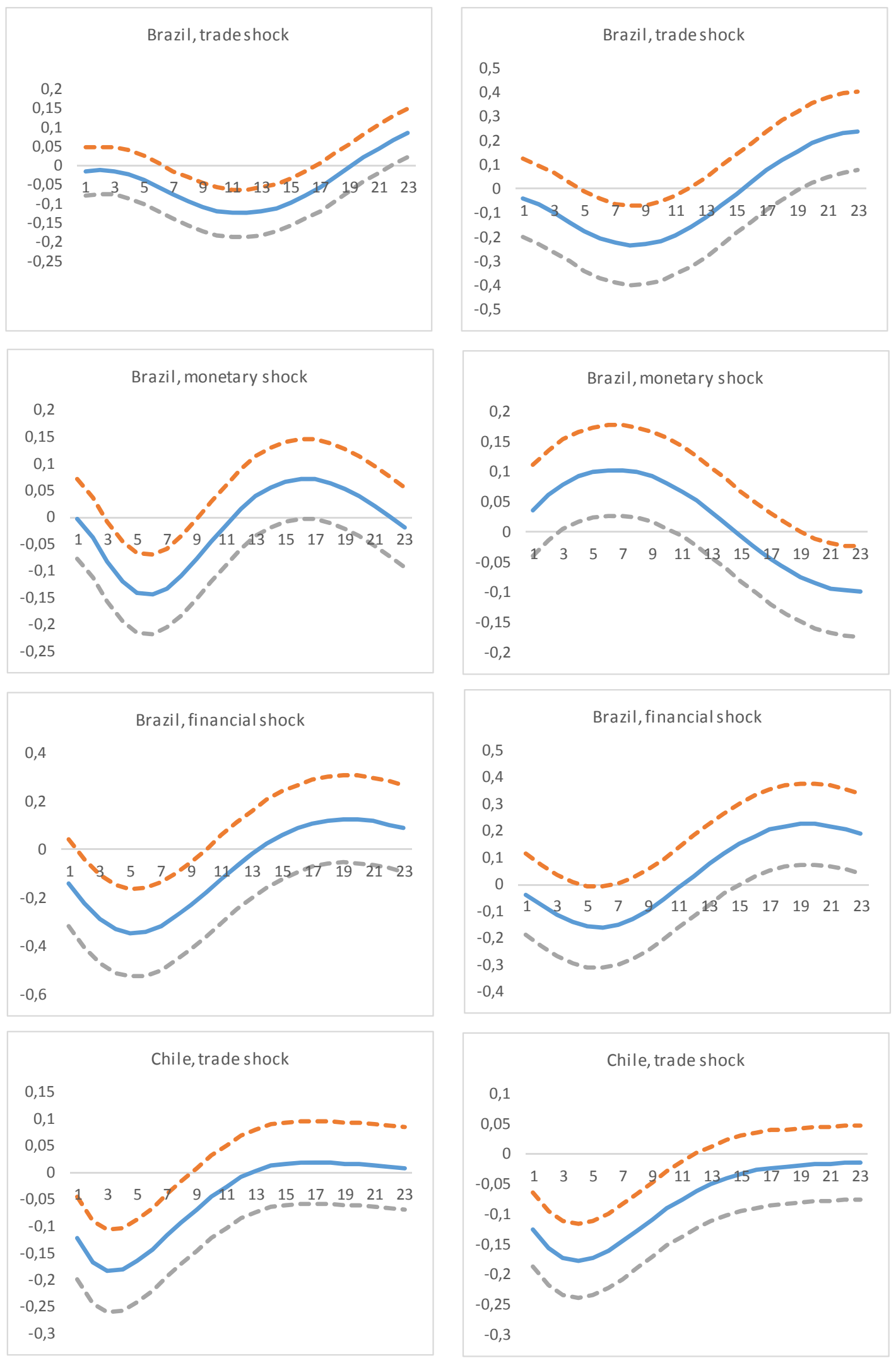

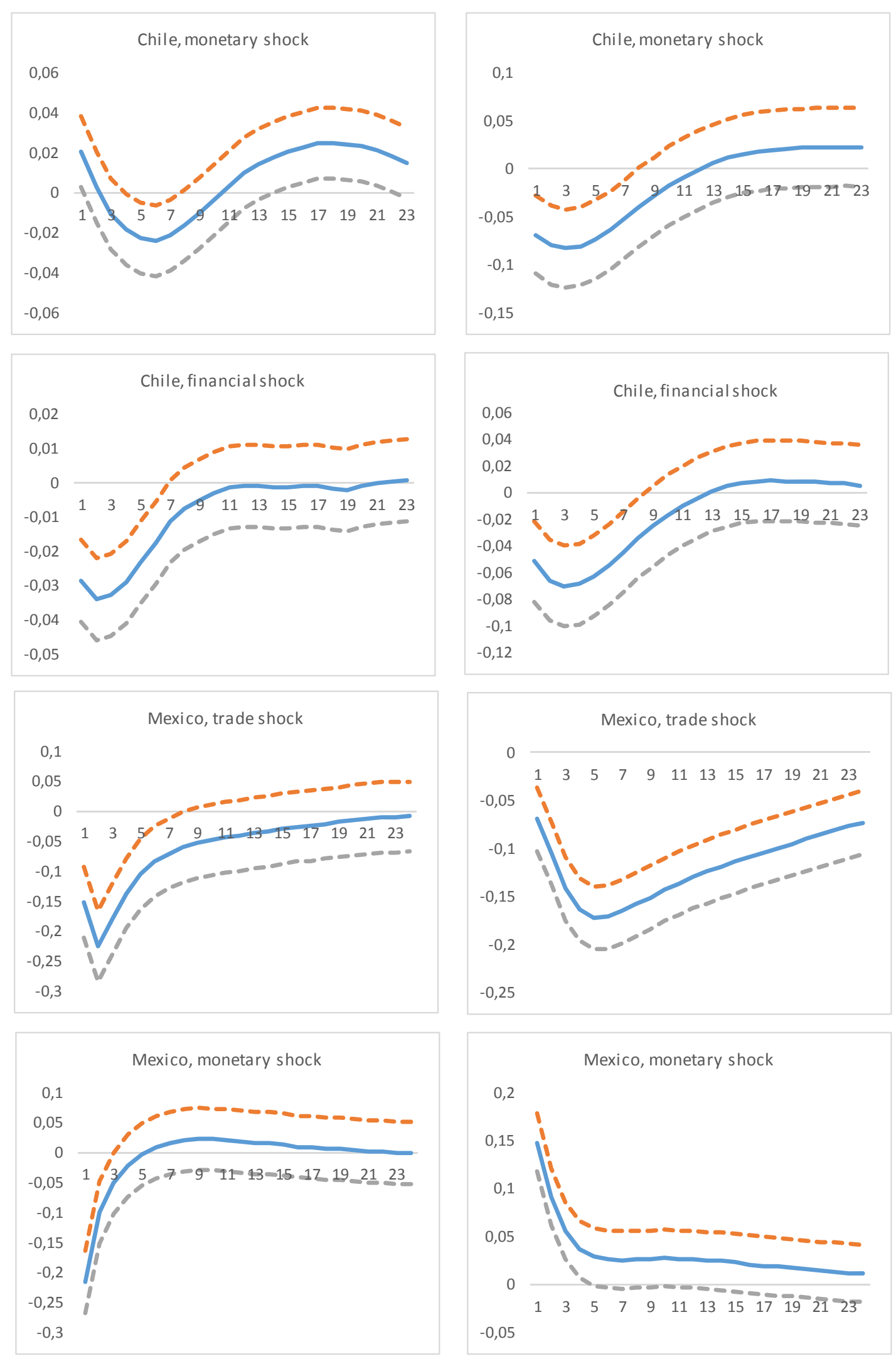

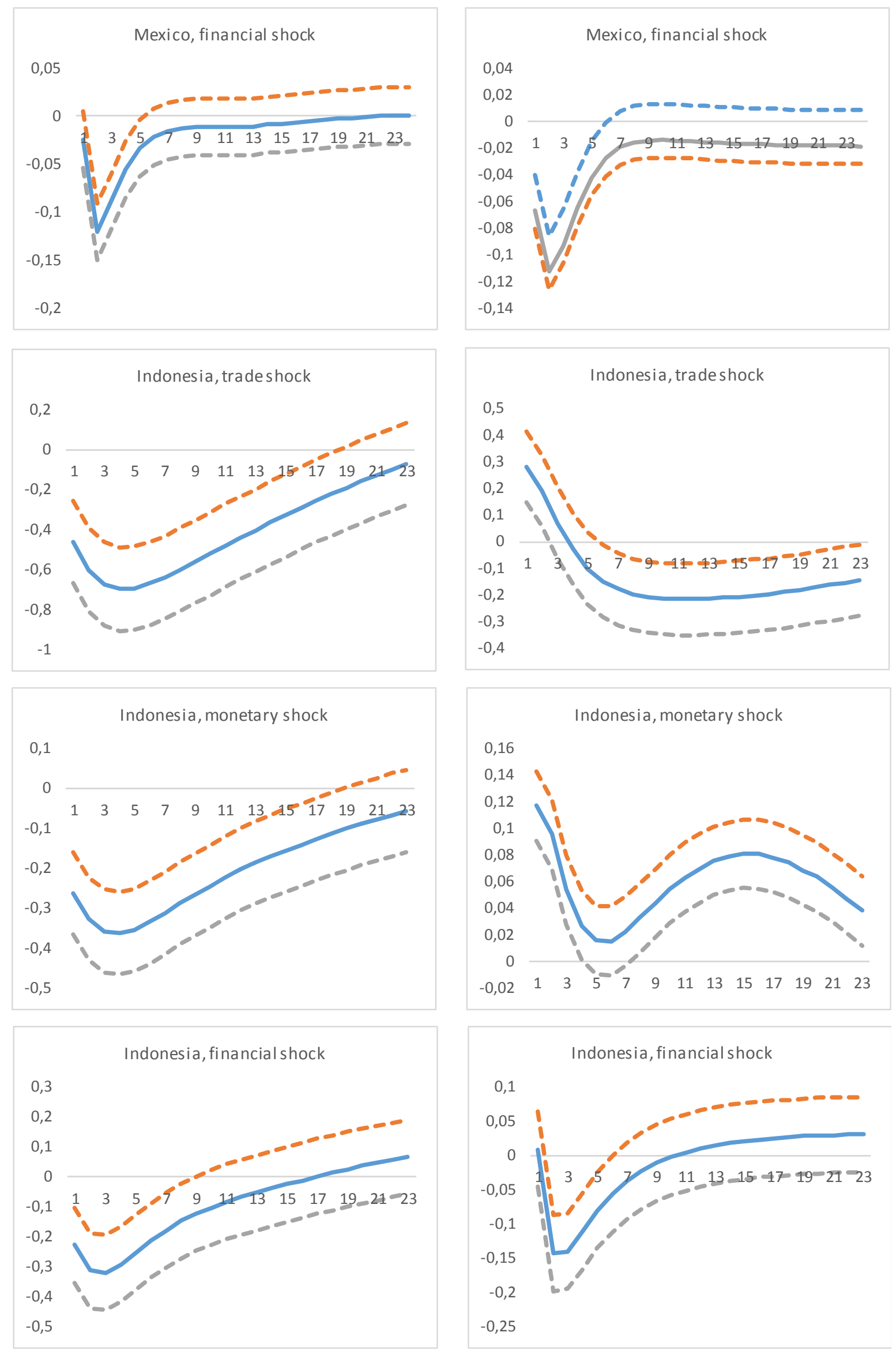

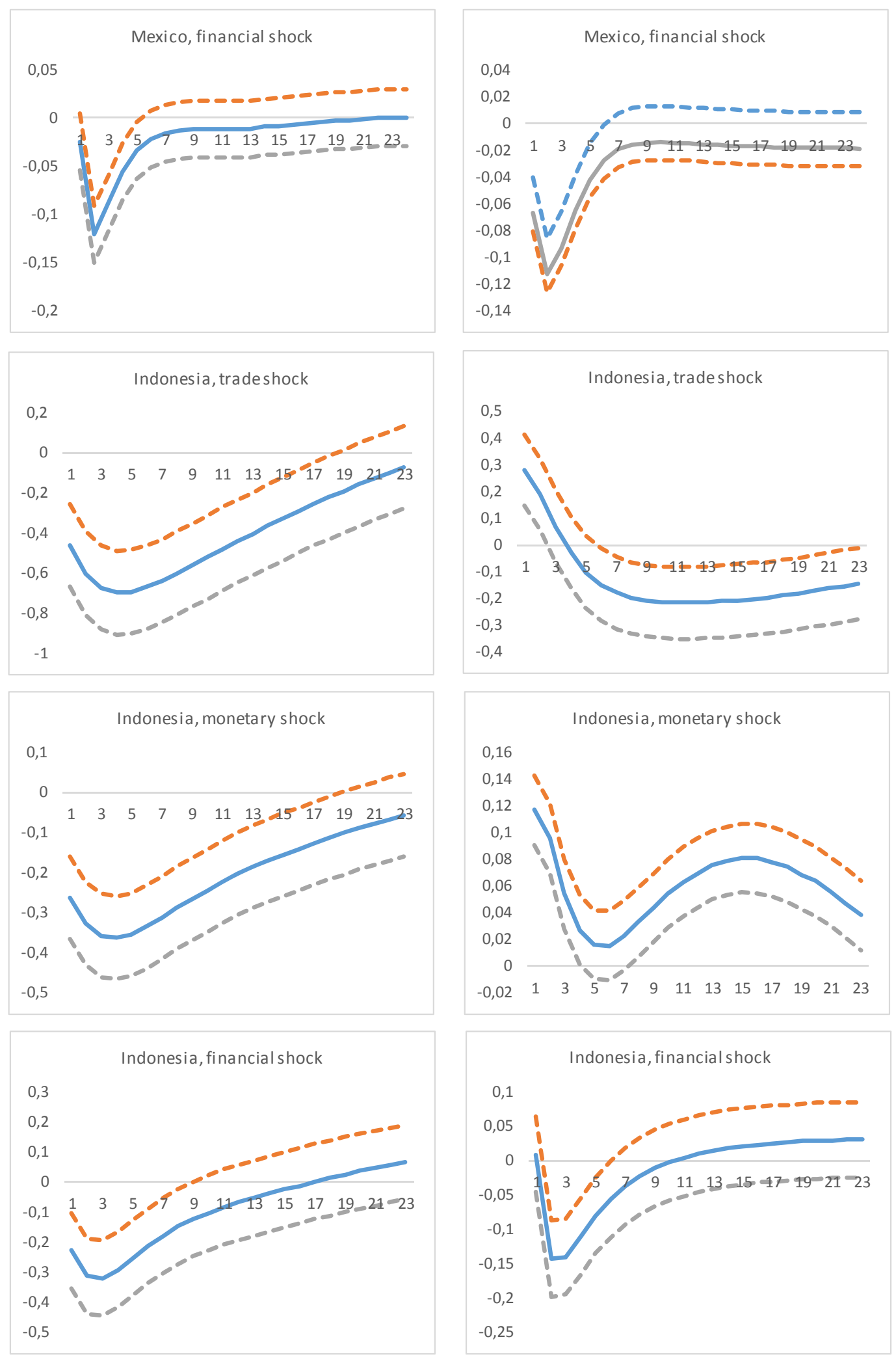

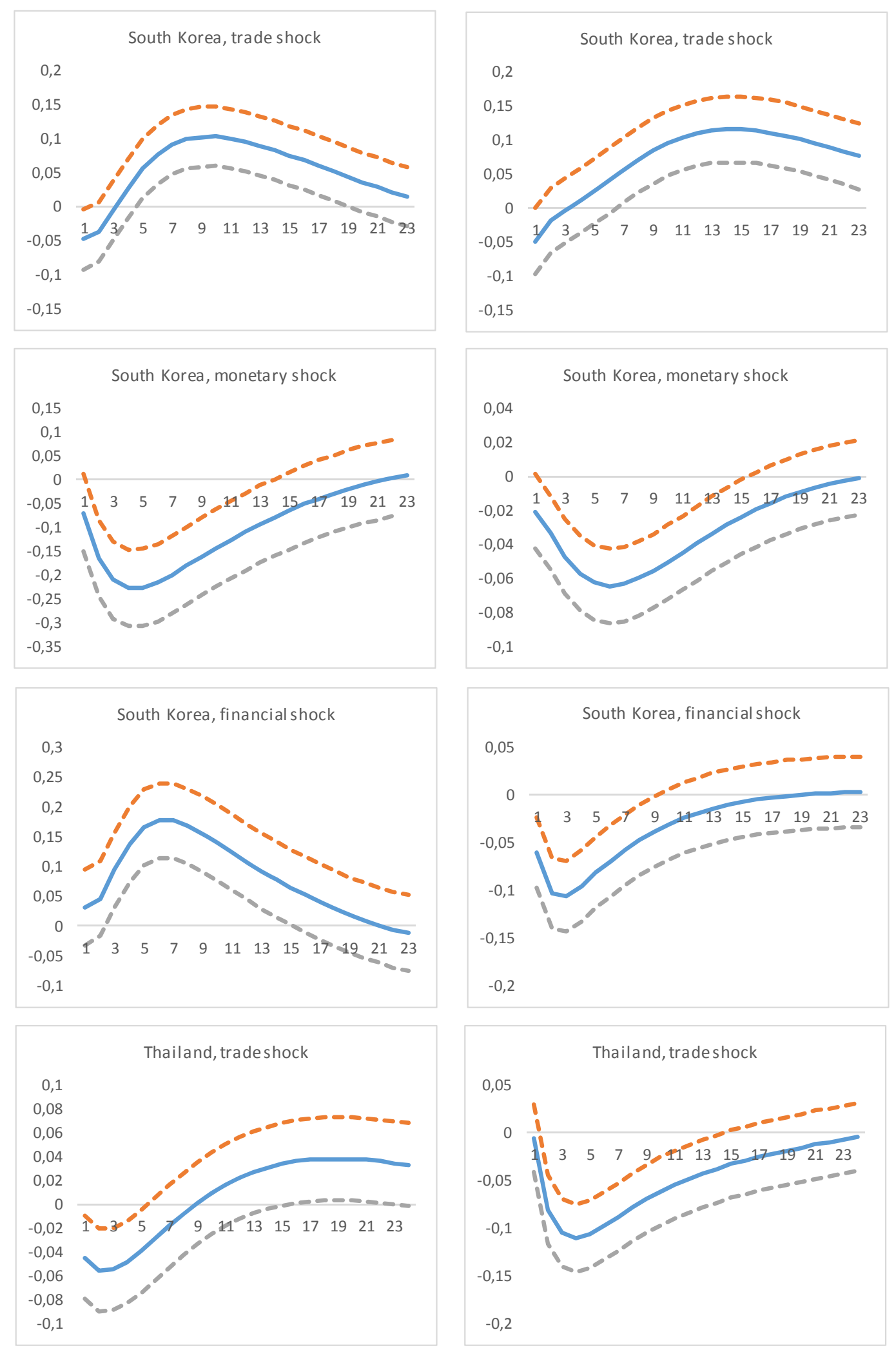

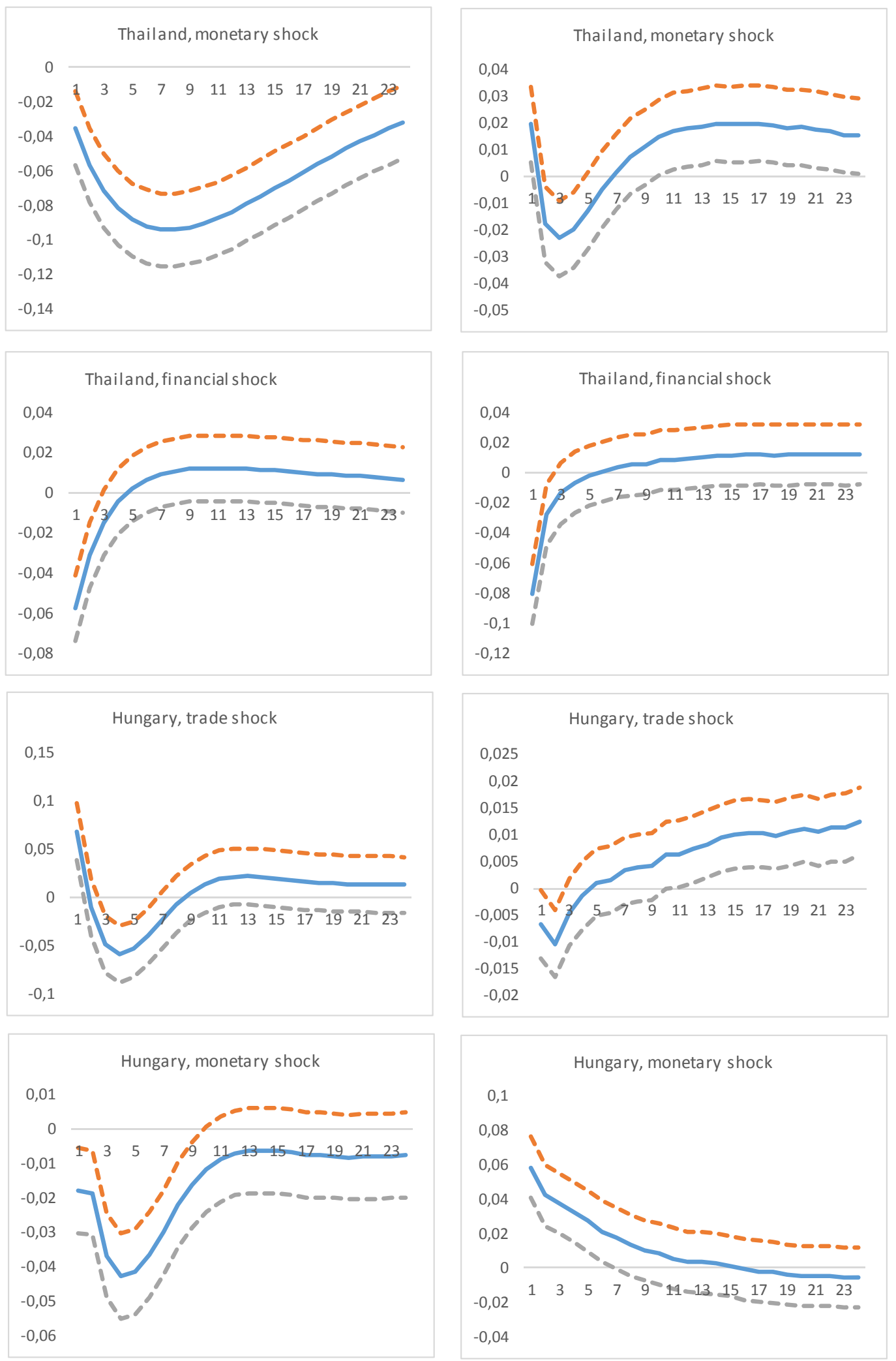

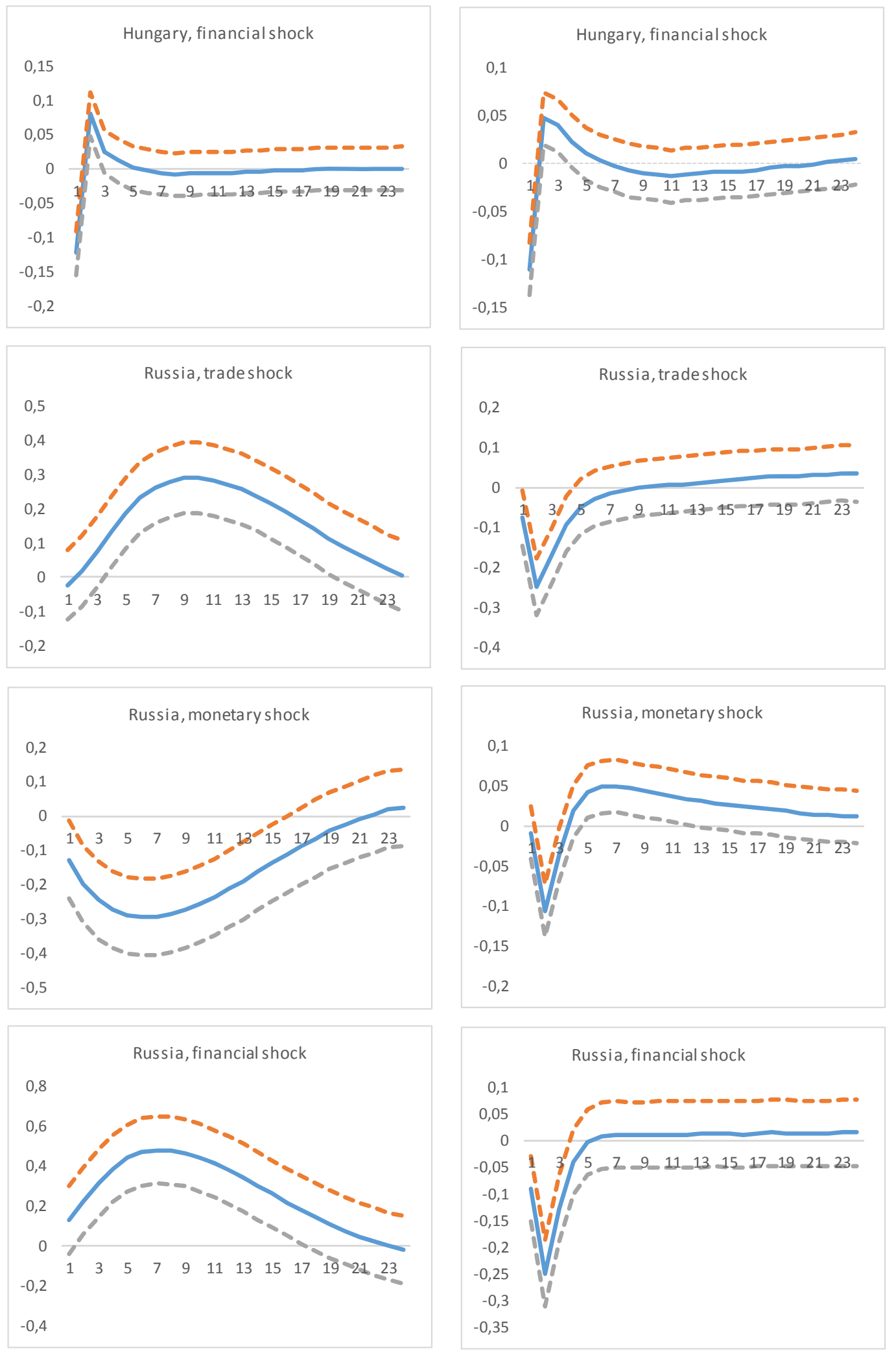

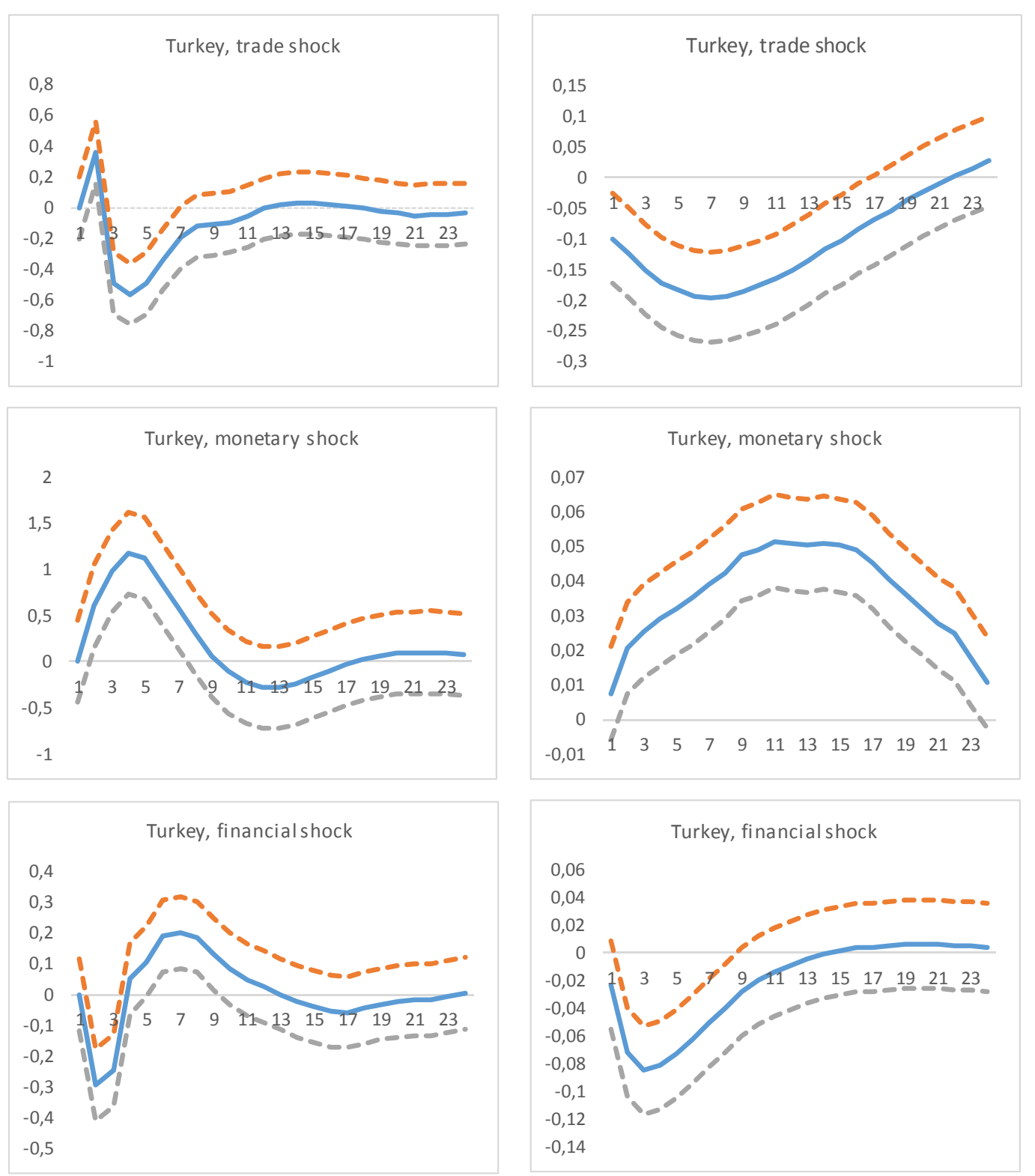
6d. Reserves over short-term external debt ratio 2004M1-2013M12
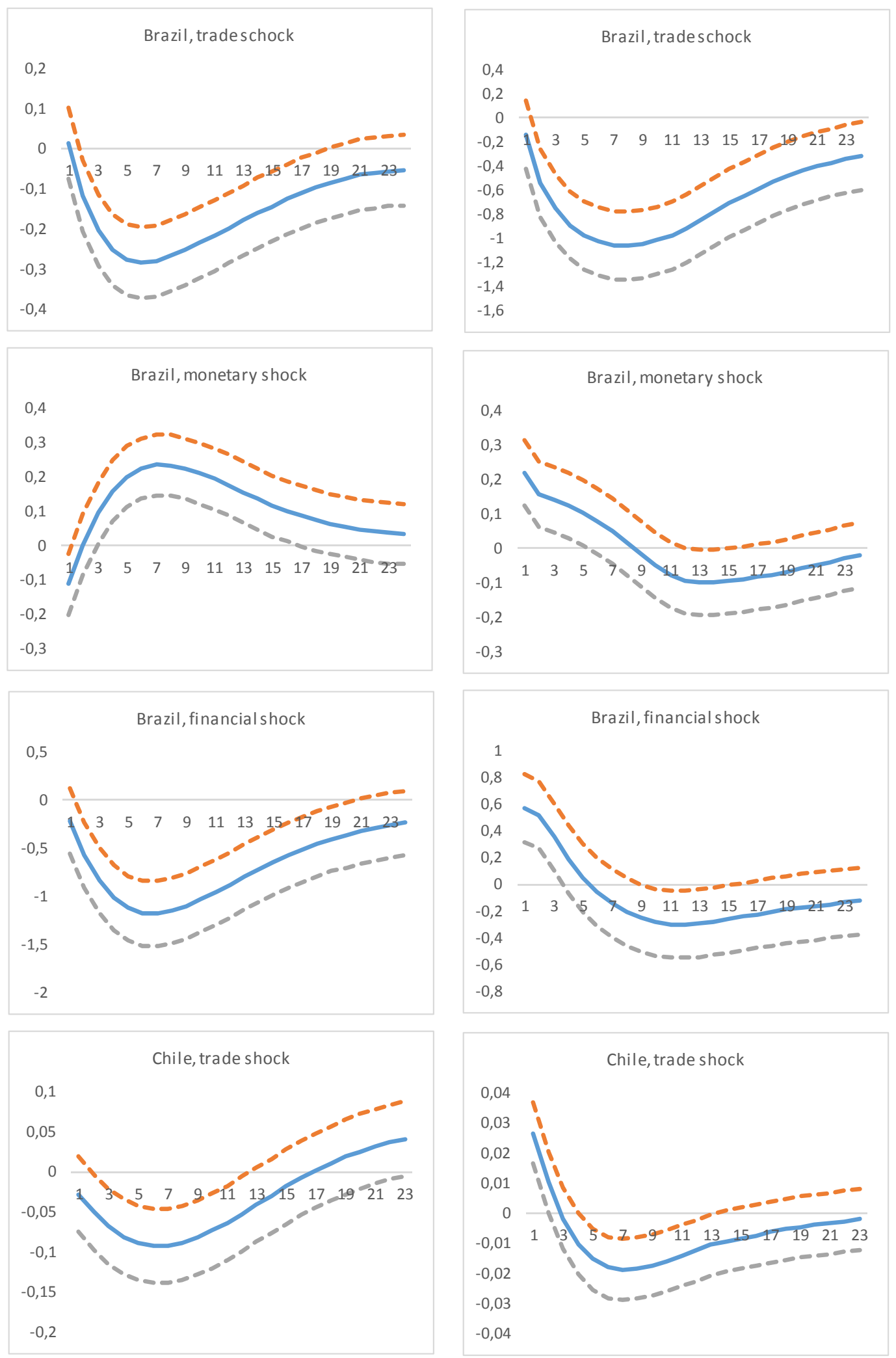

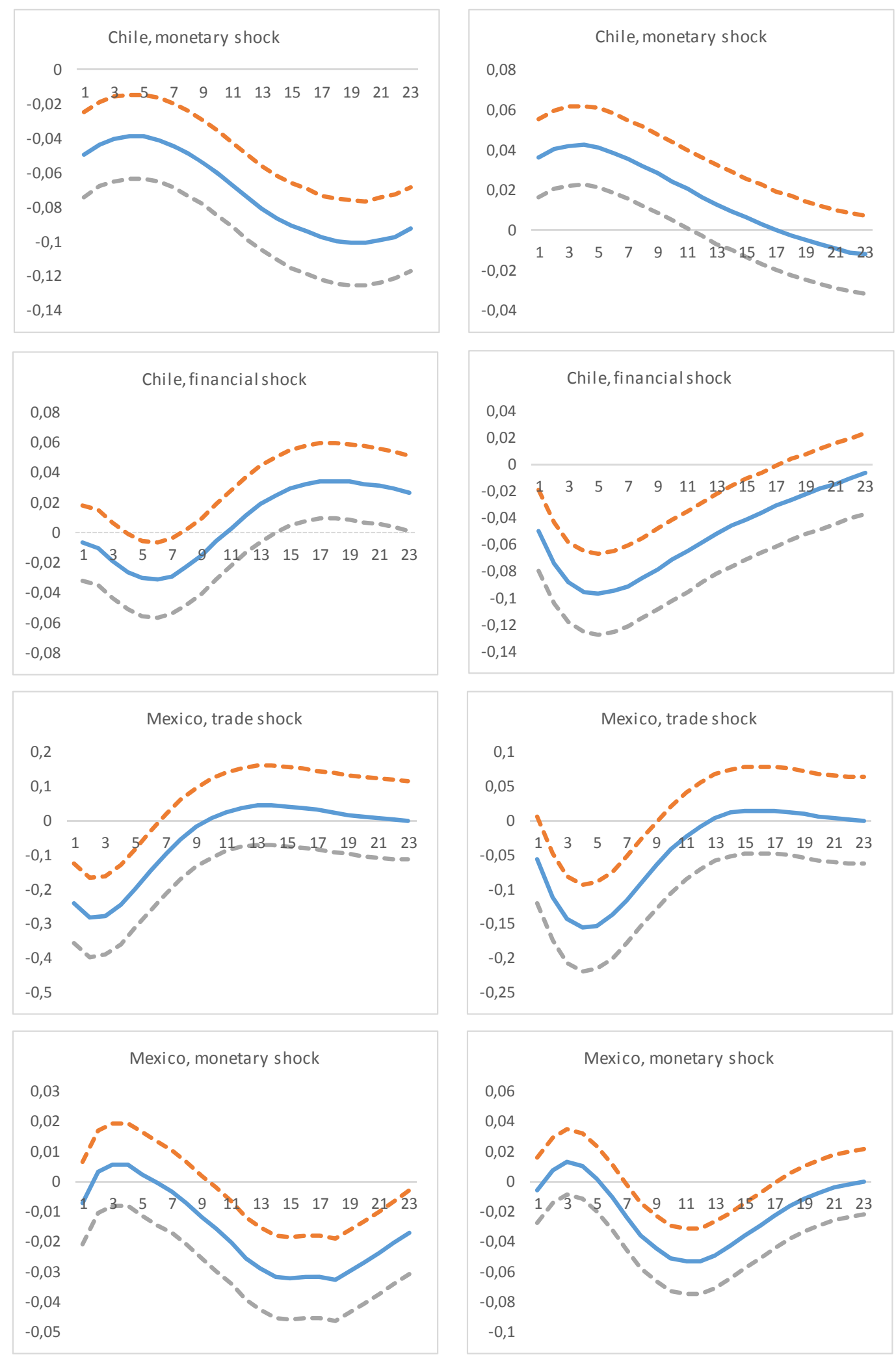

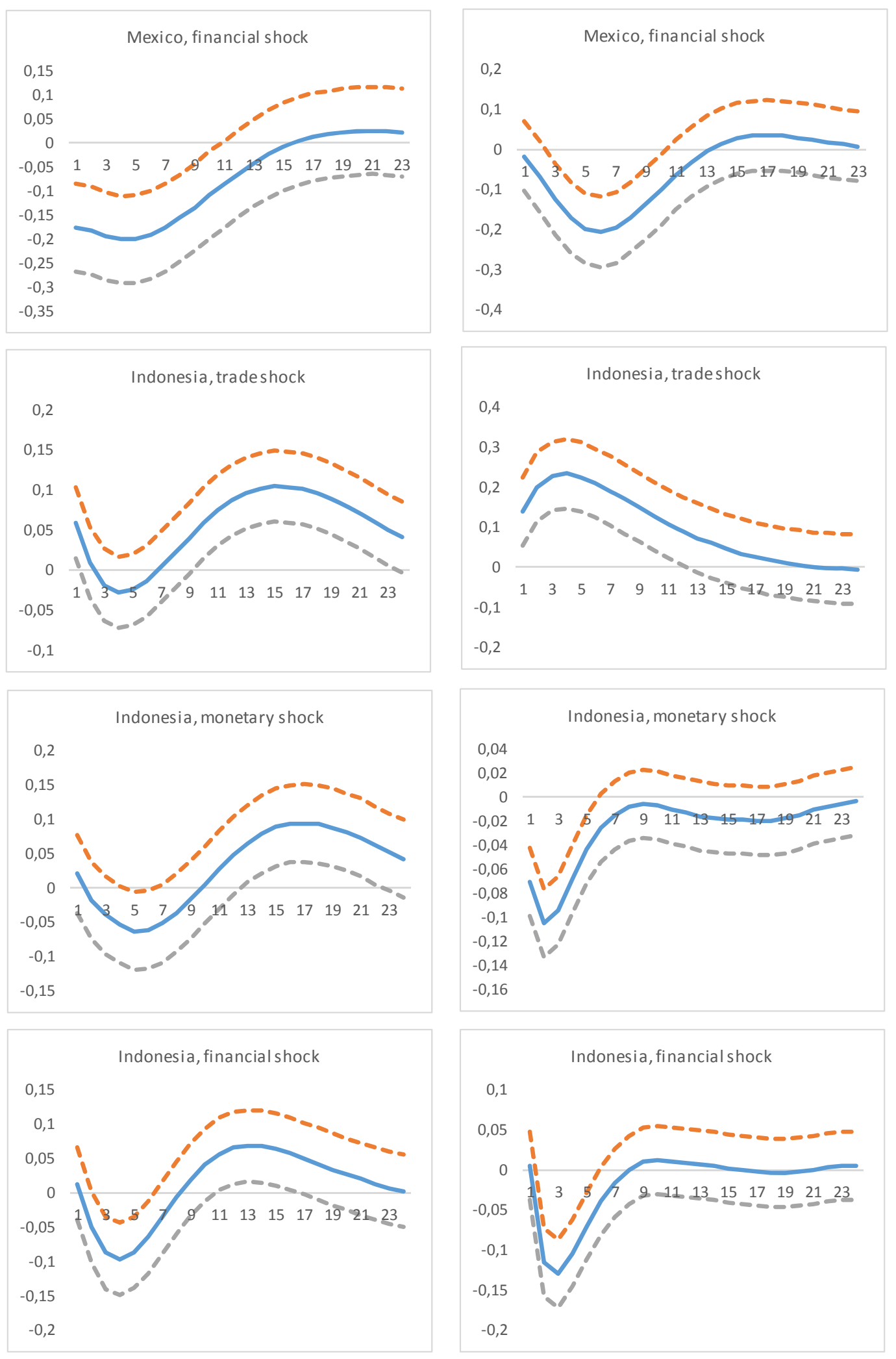

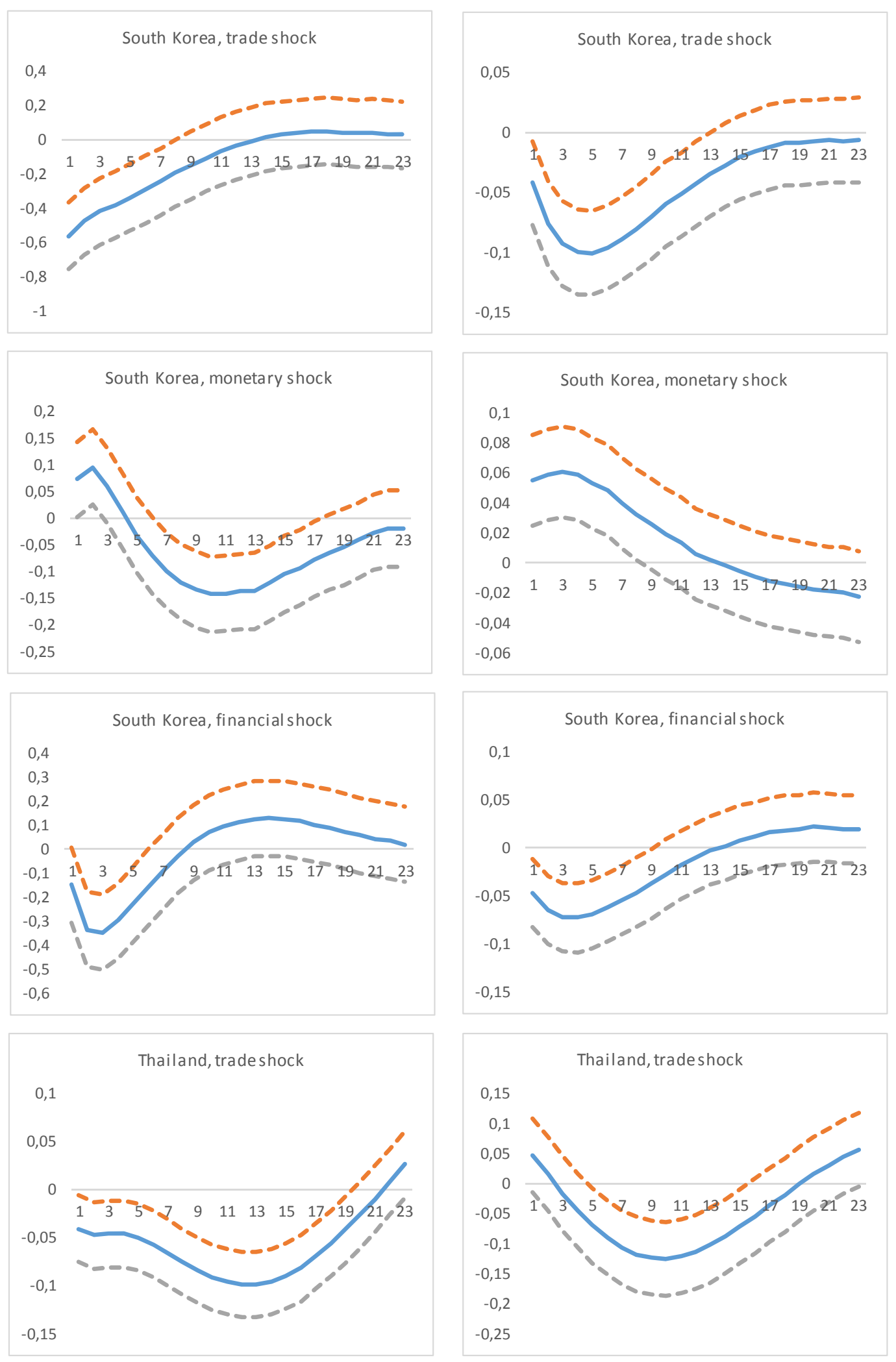

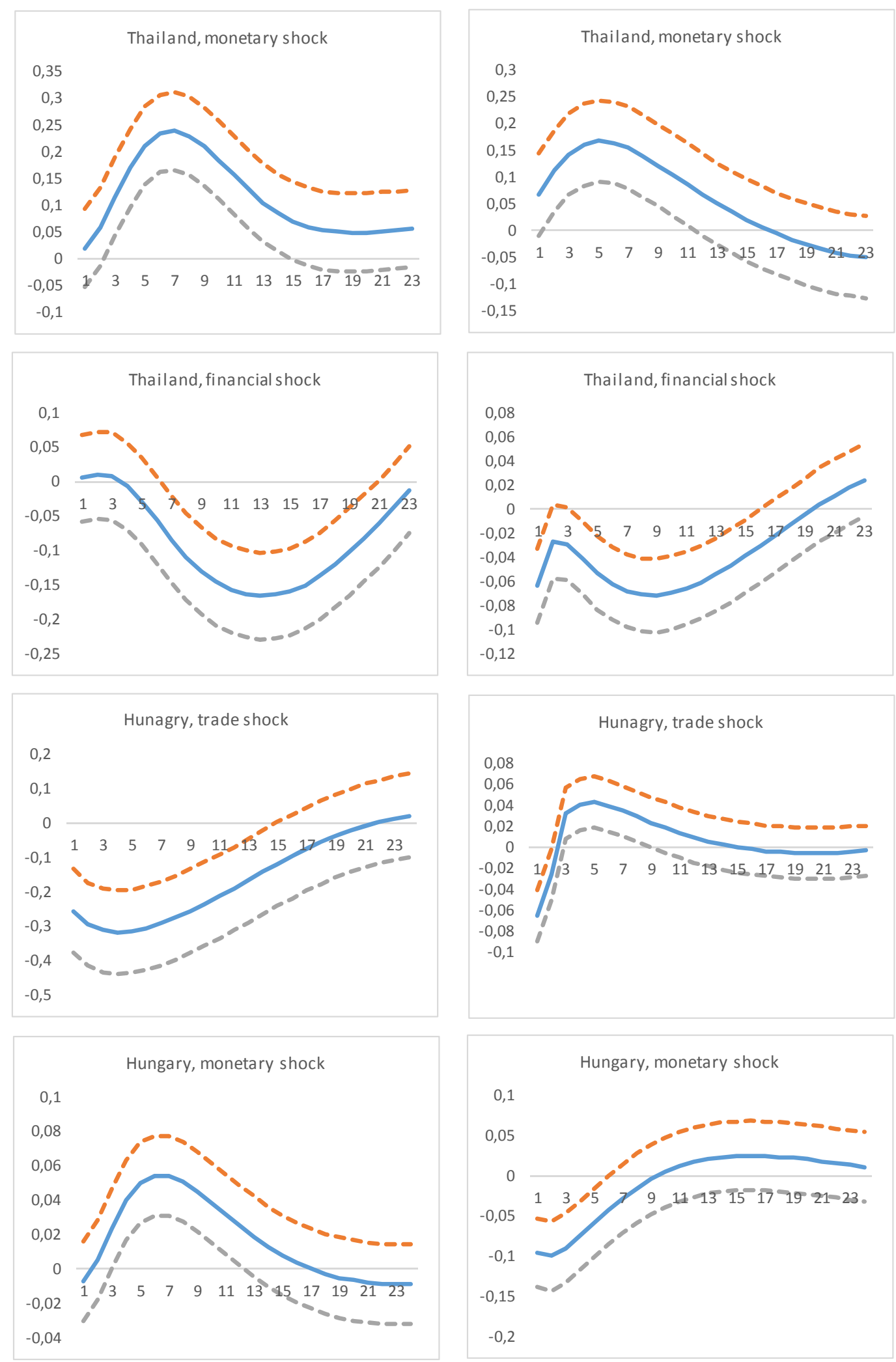

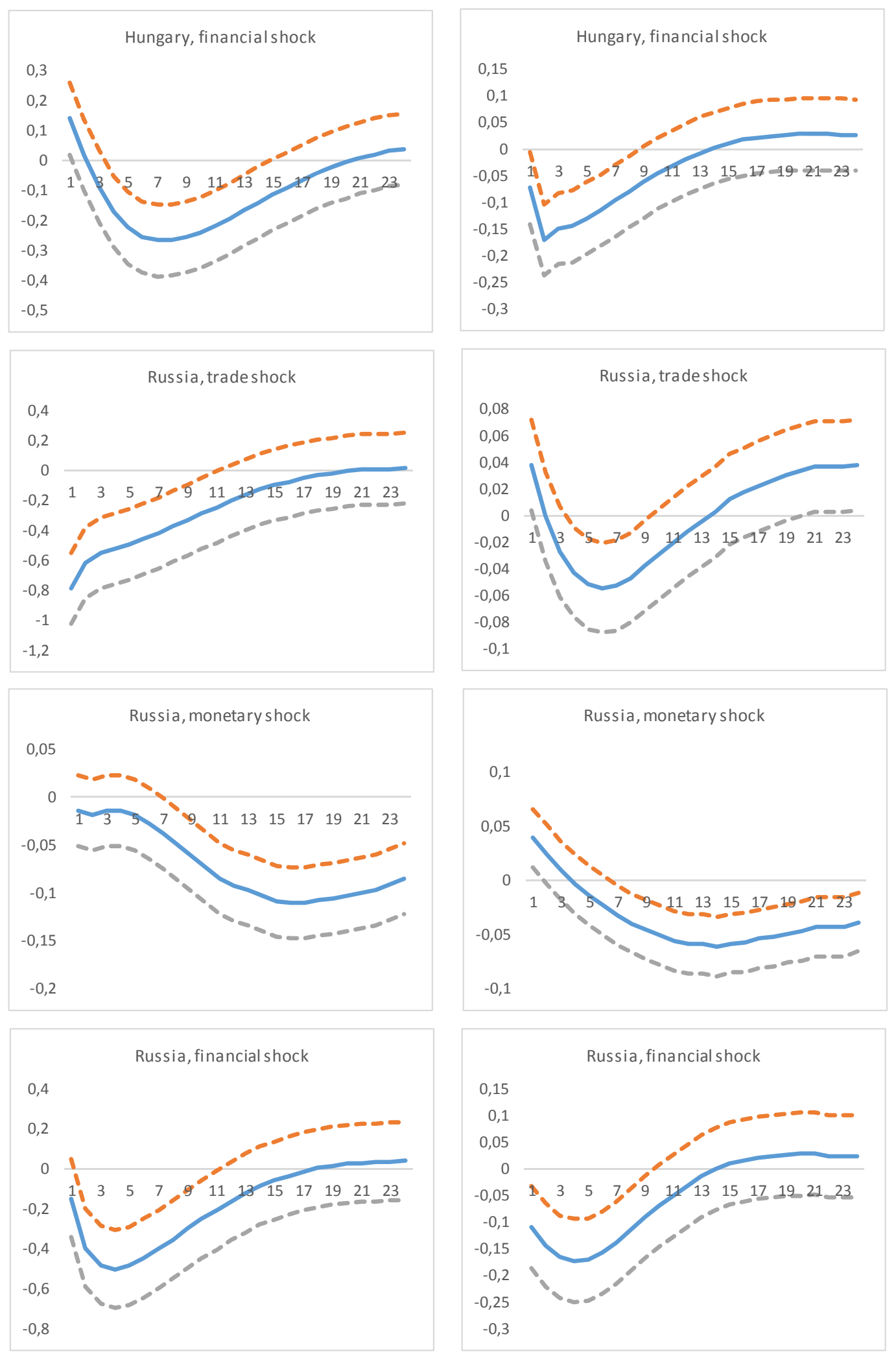

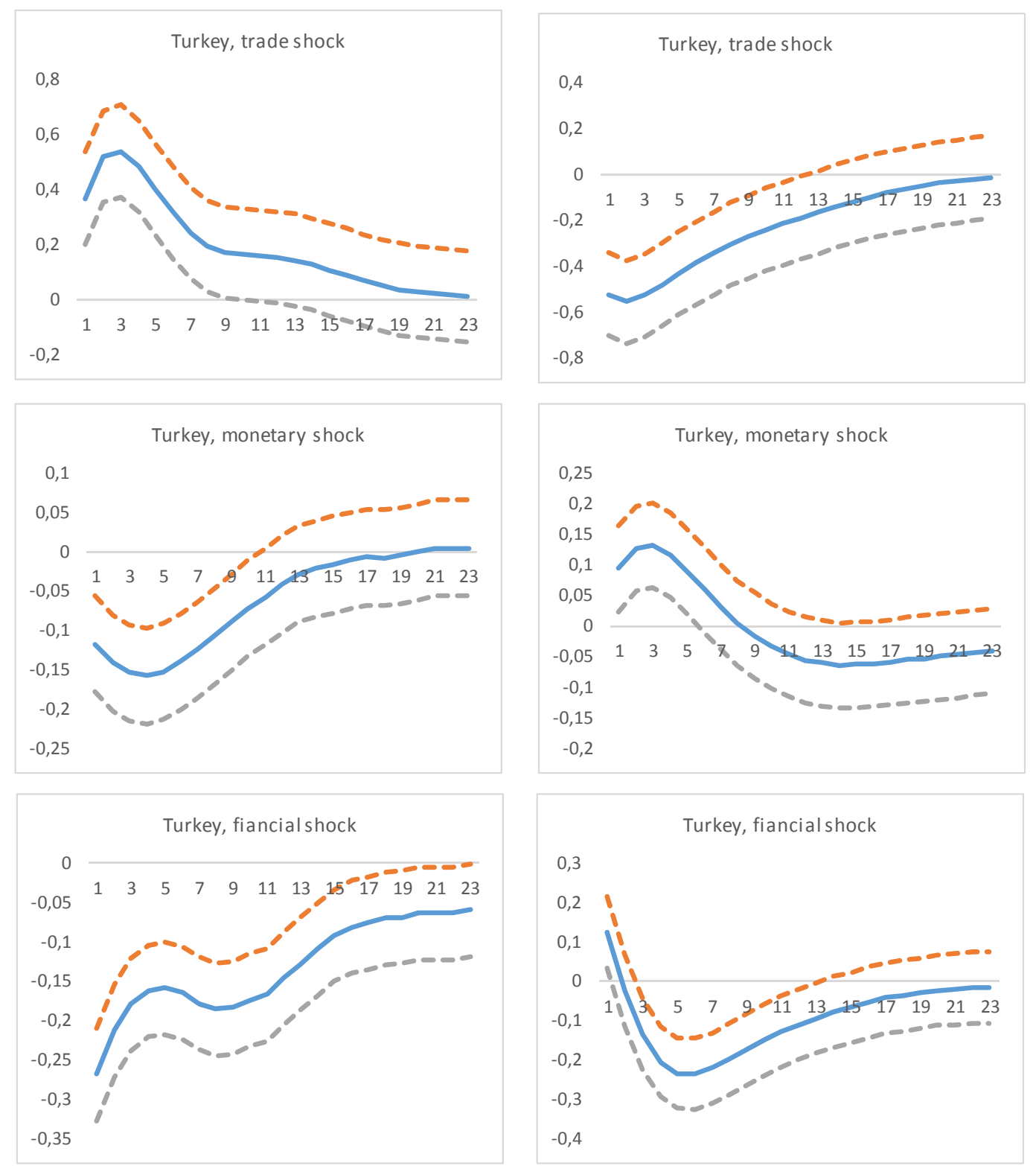
6f. Reserves over M2 ratio 1995M1-2003M12
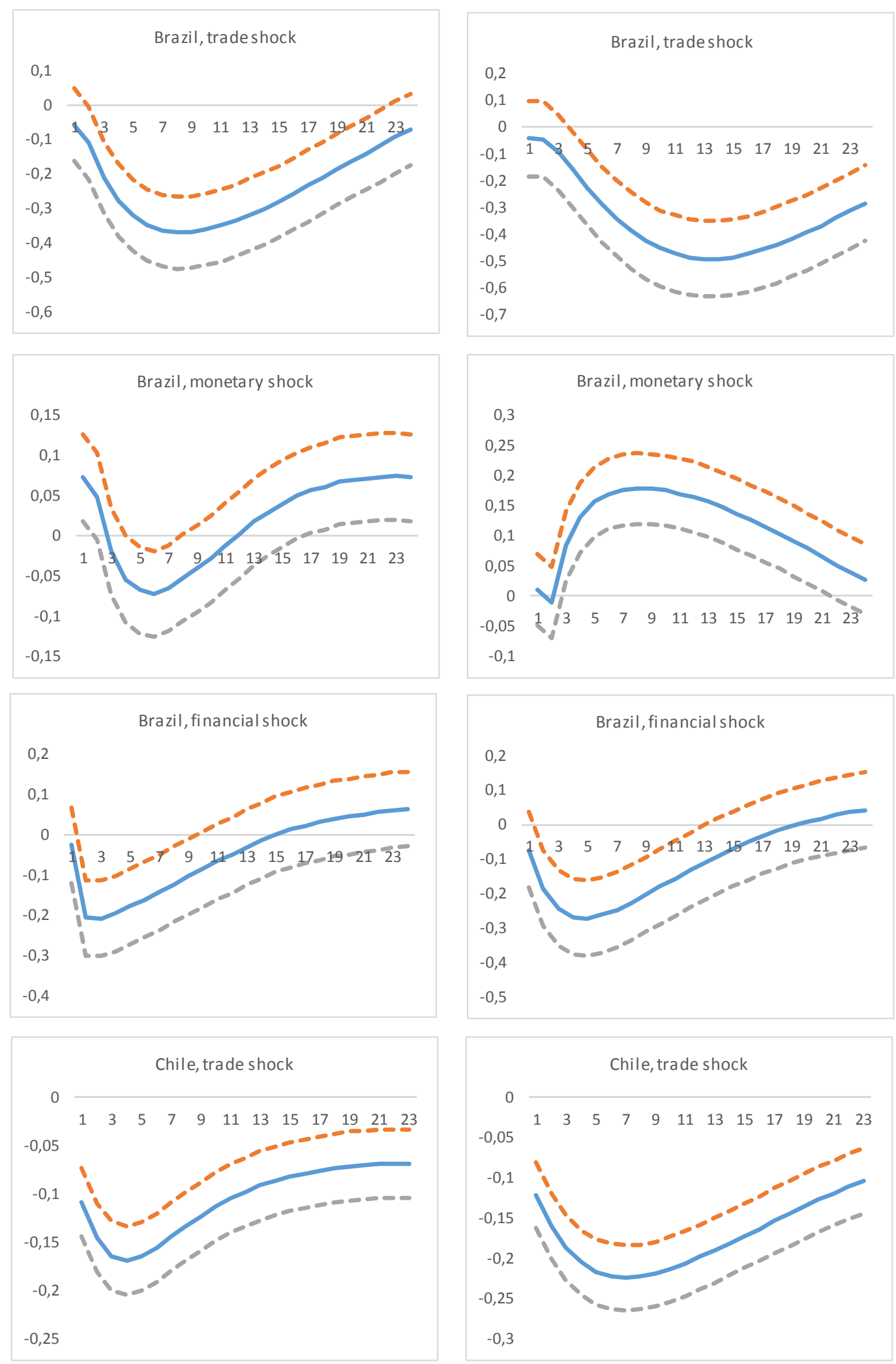

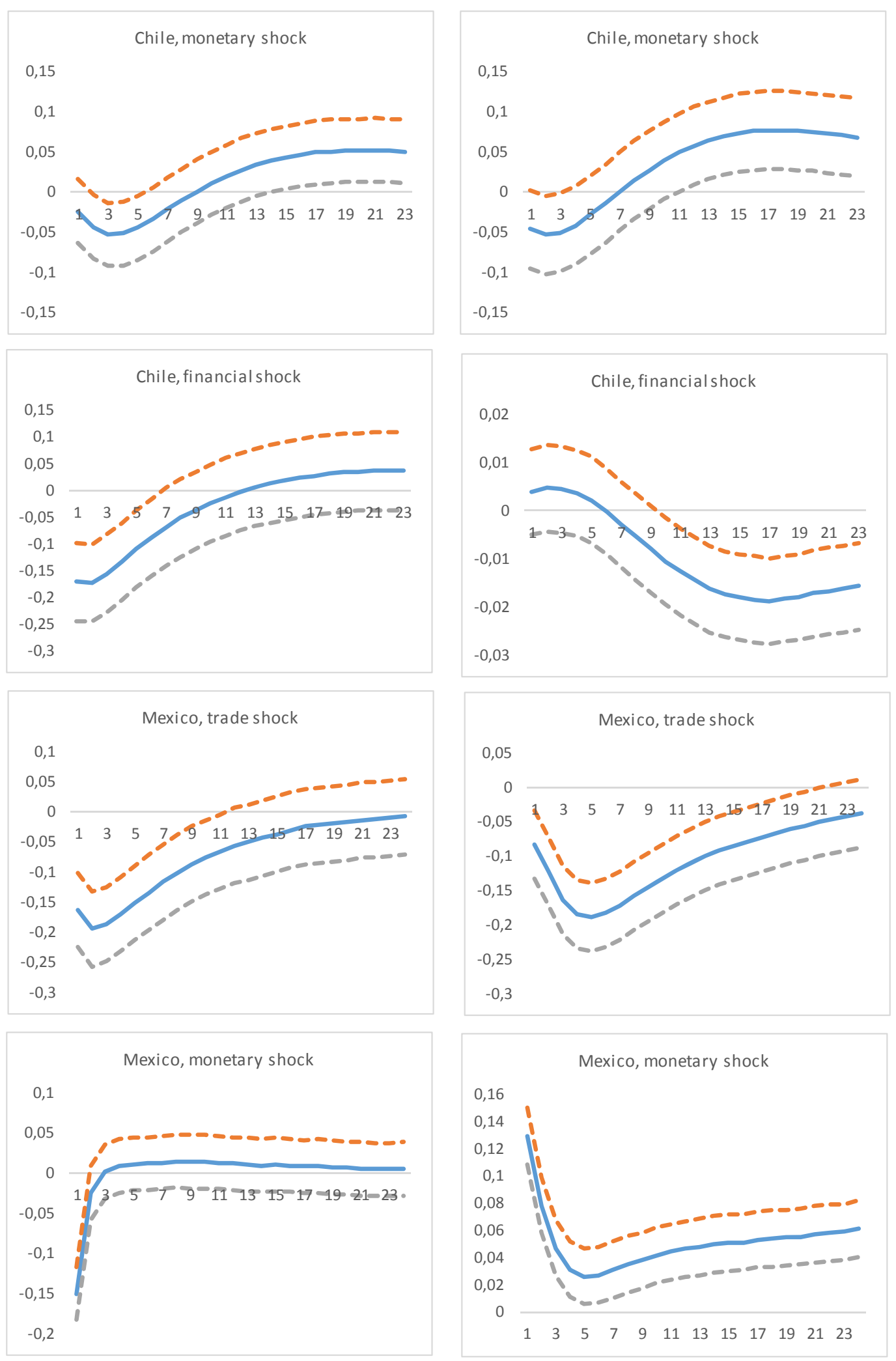

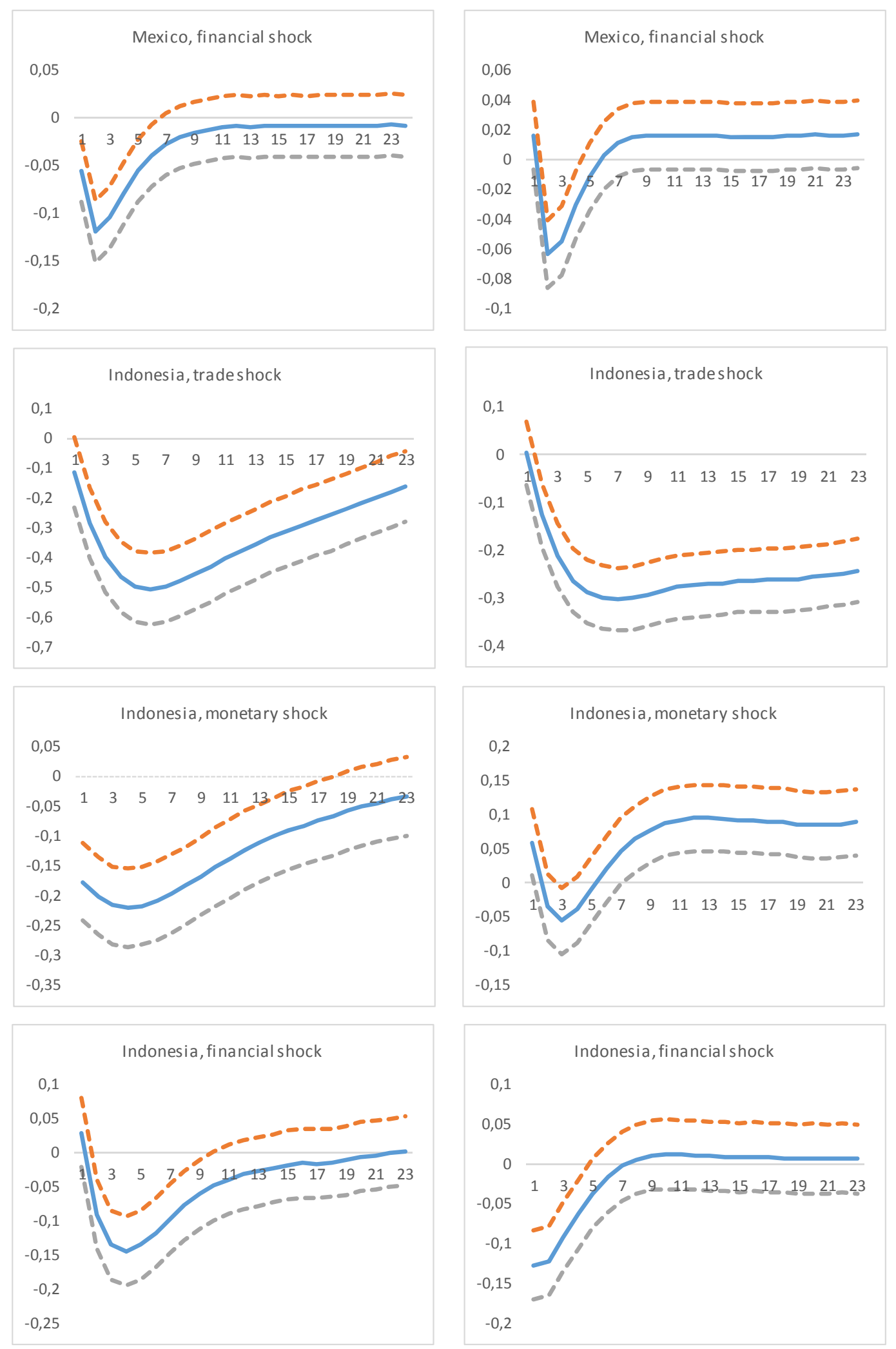

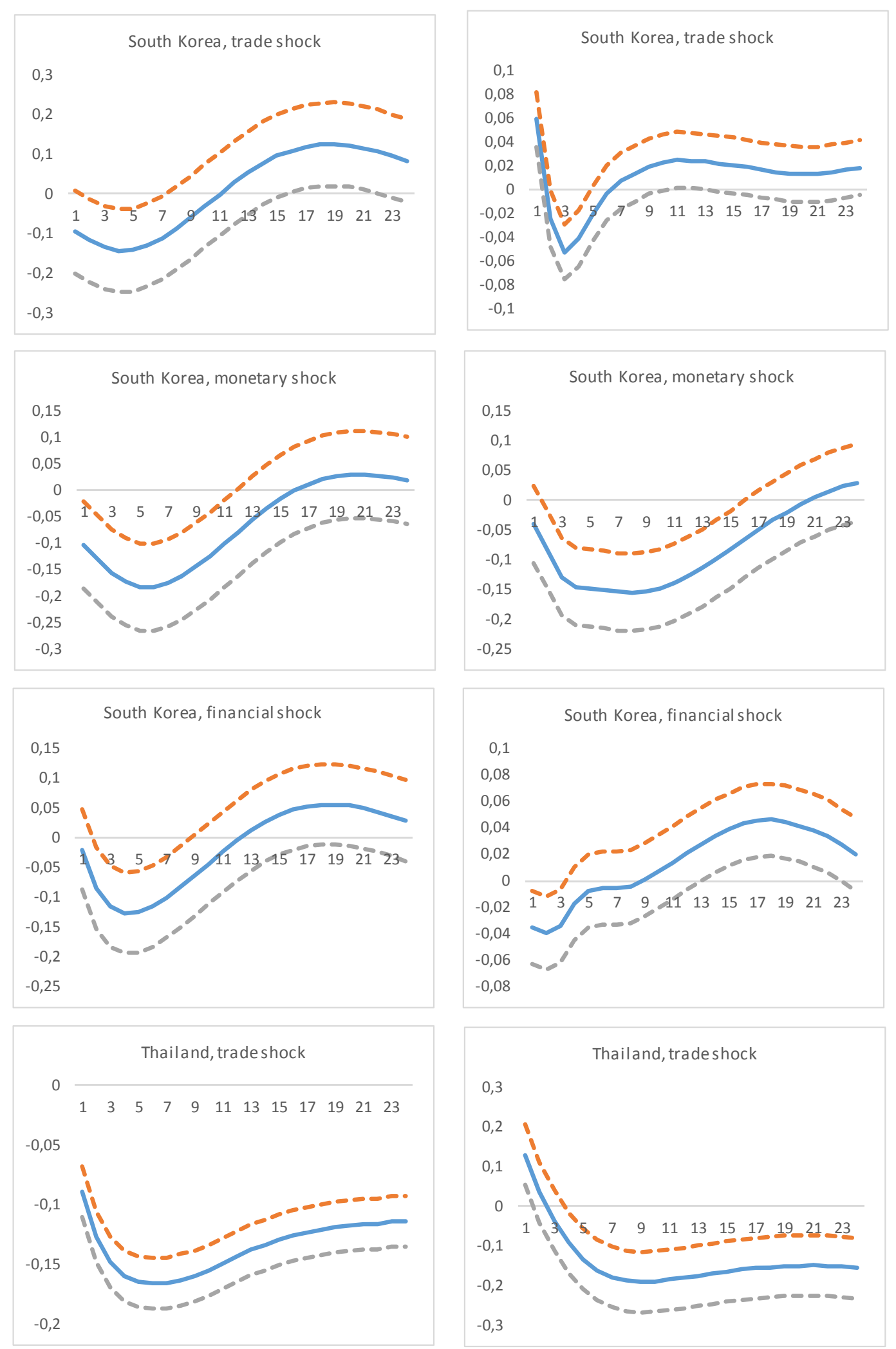

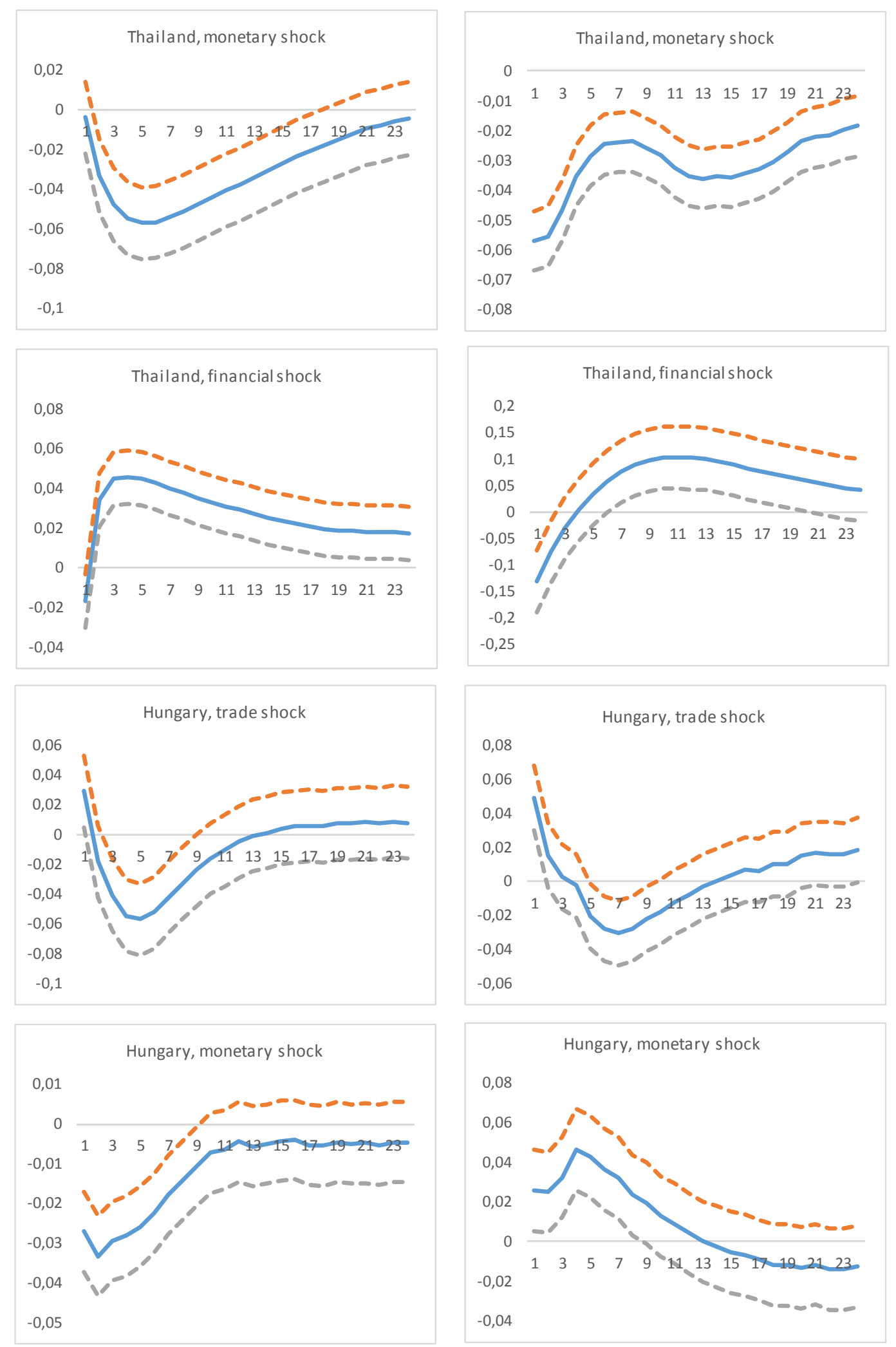

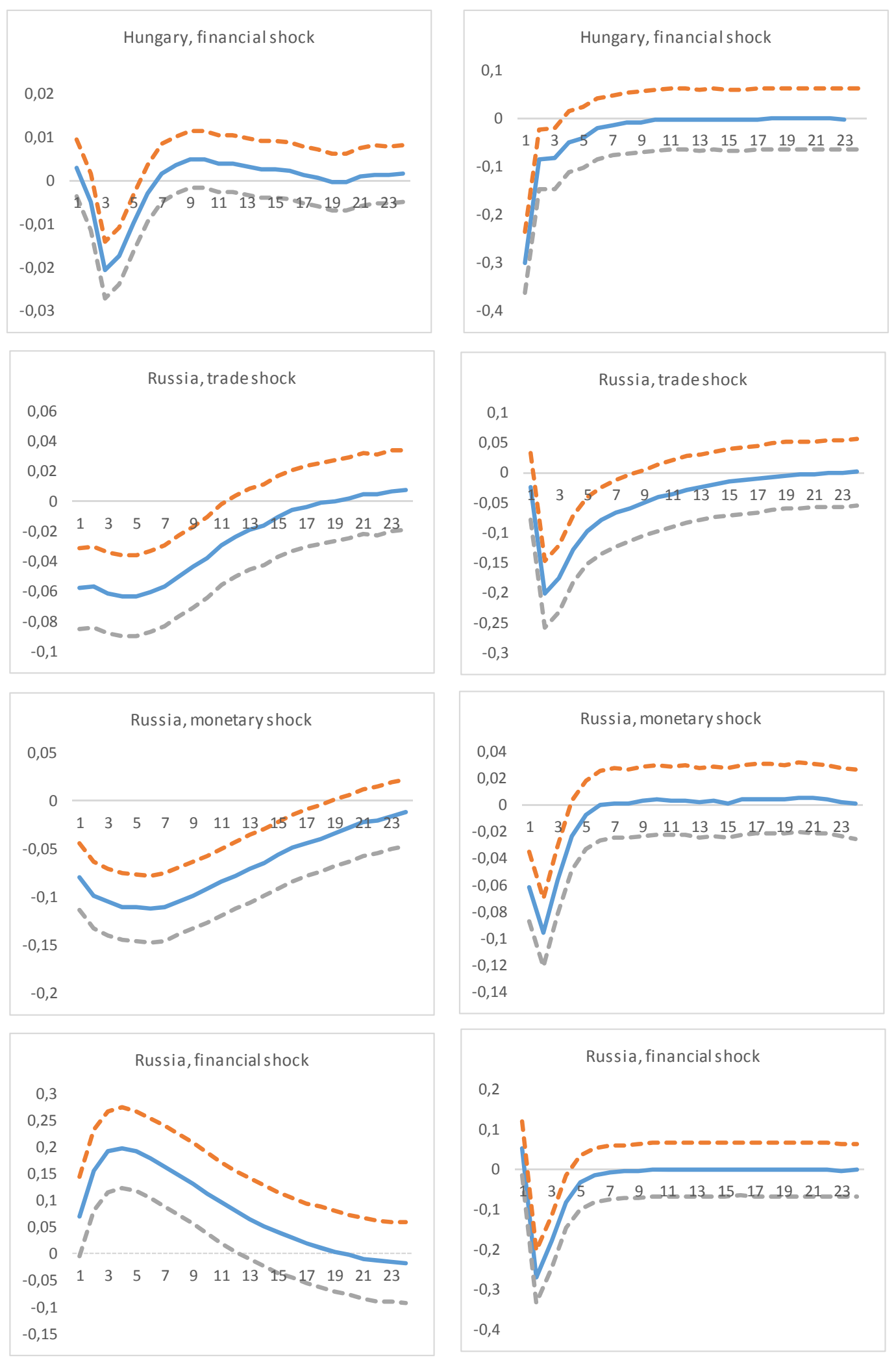

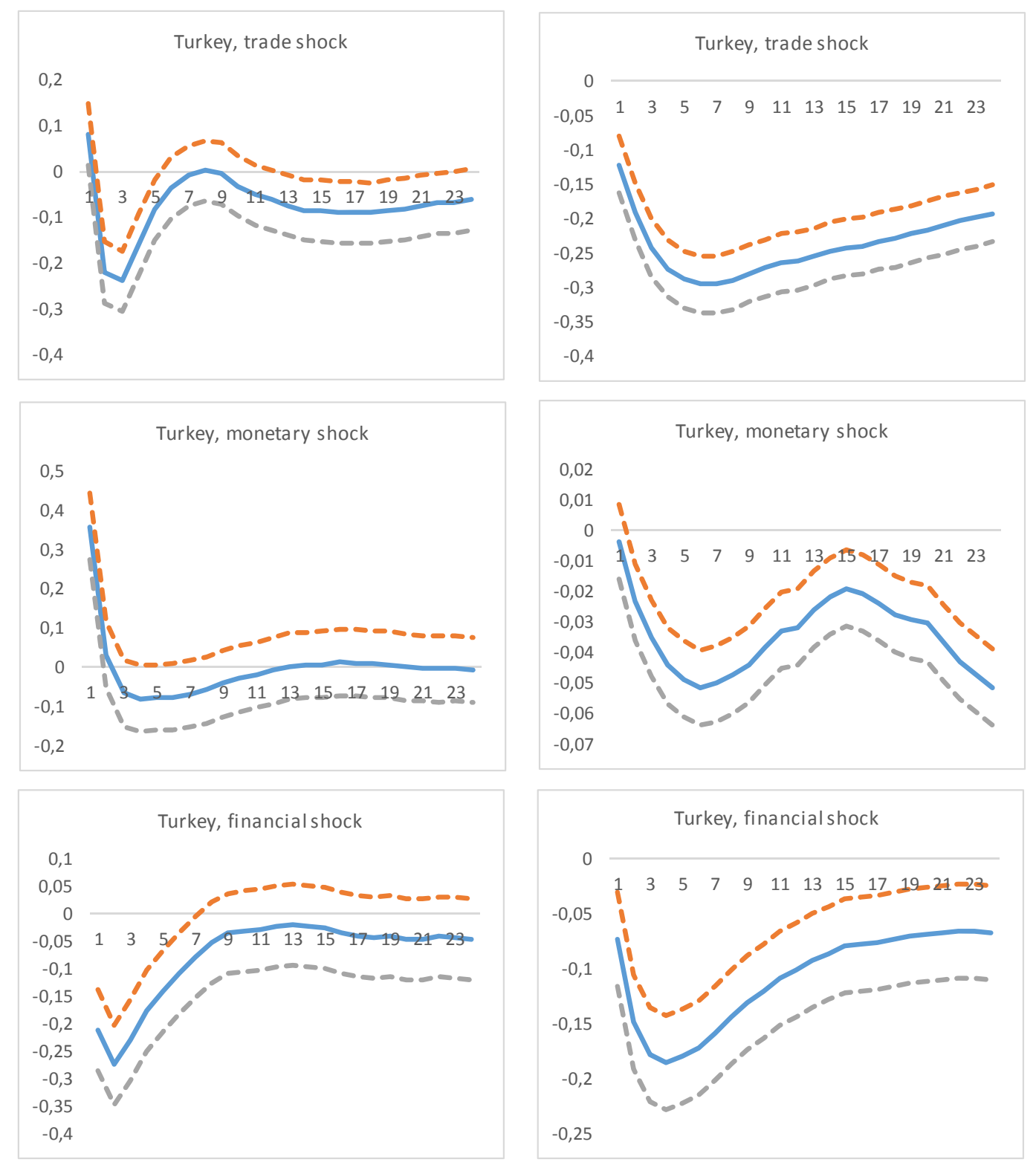
6g. Reserves over M2 ratio 2004M1-2013M12
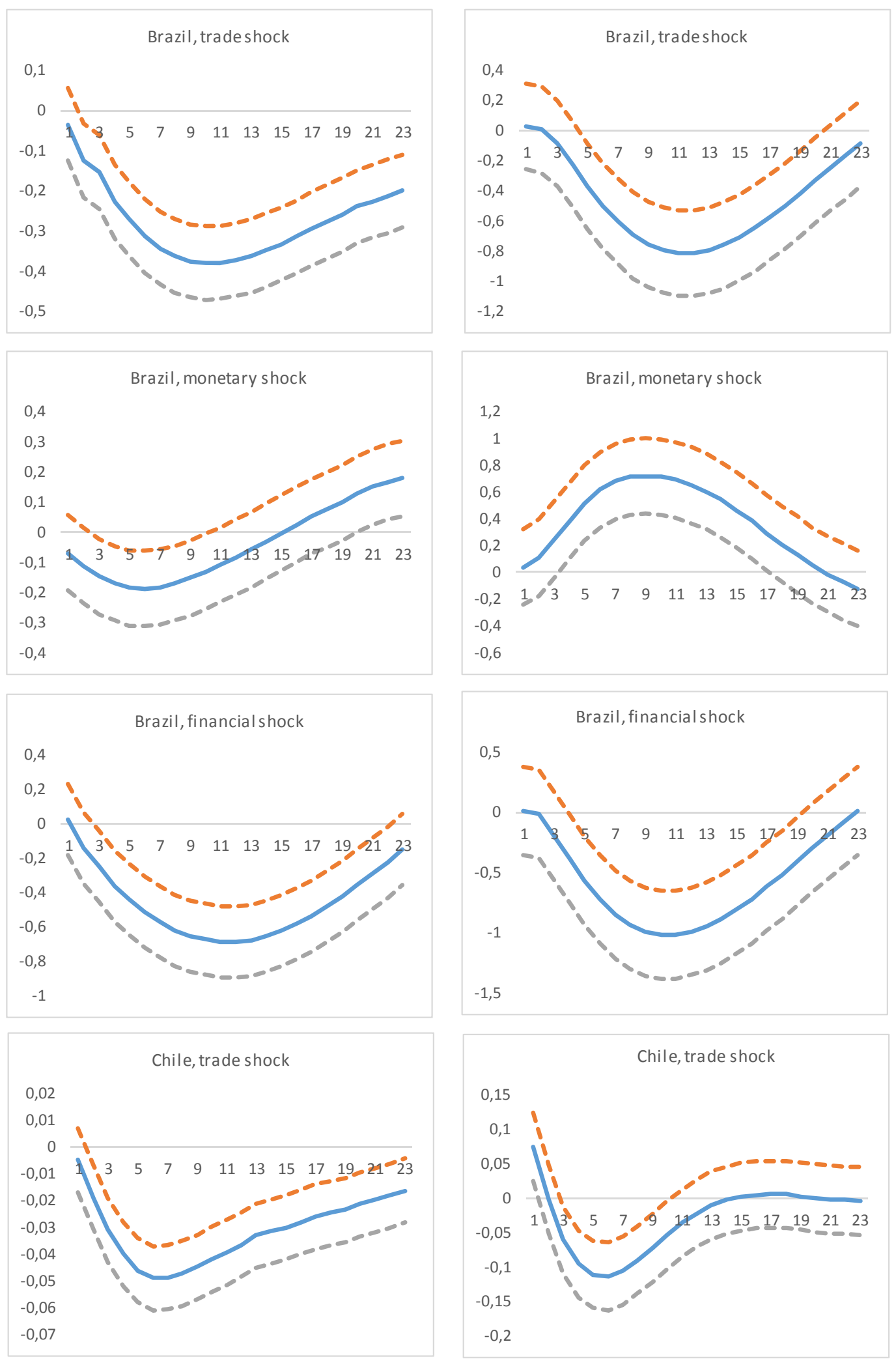

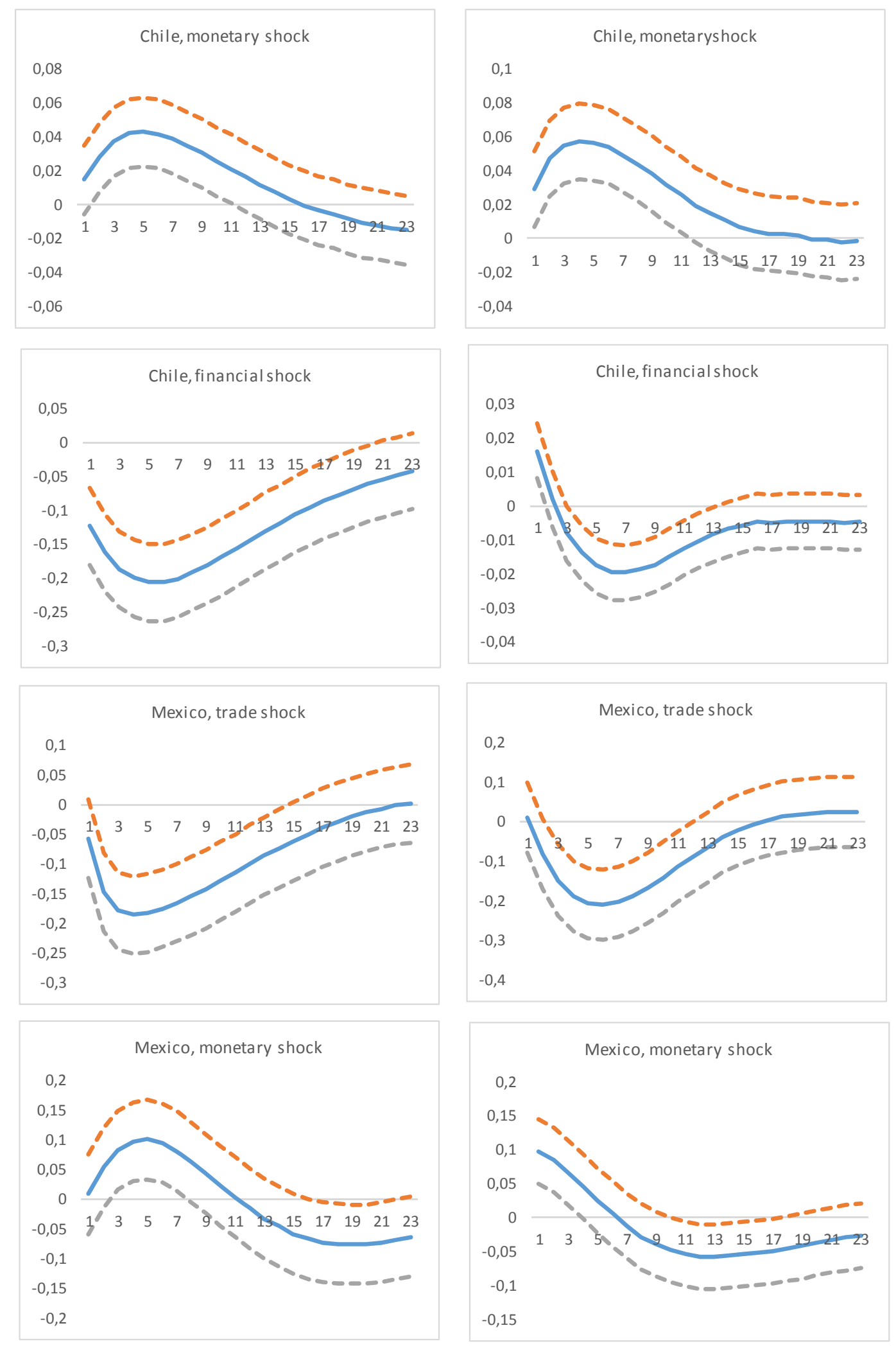

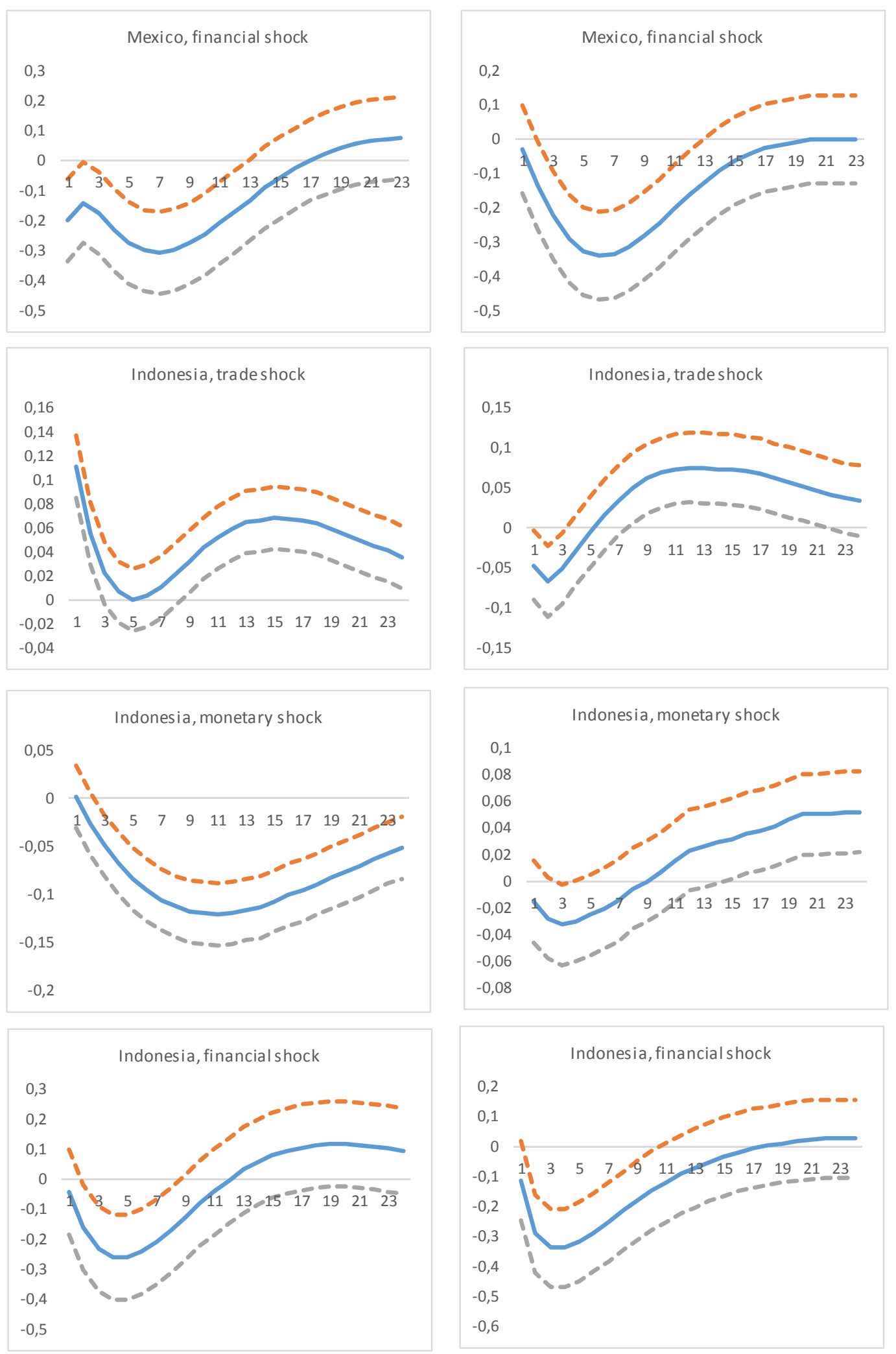

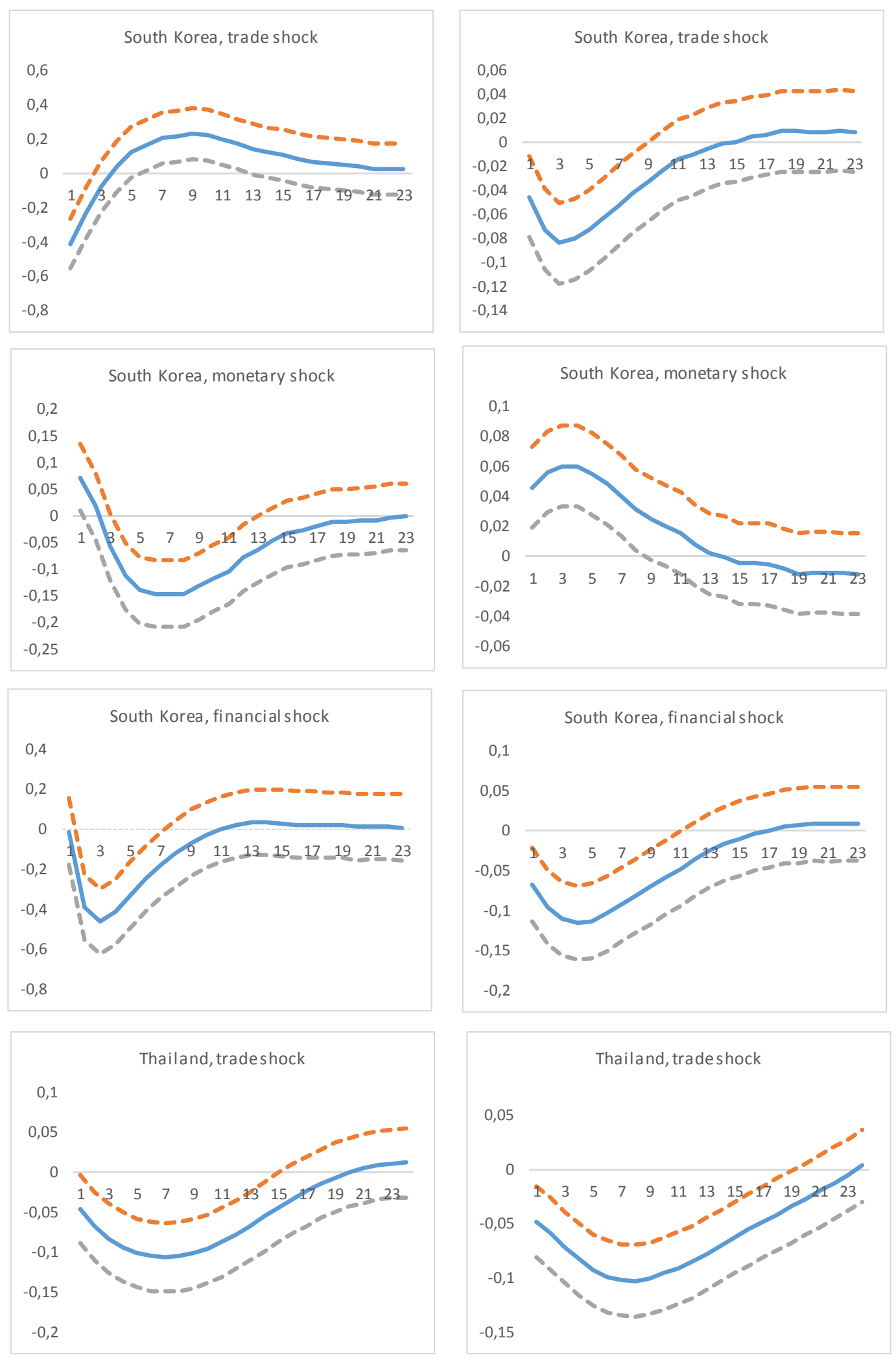

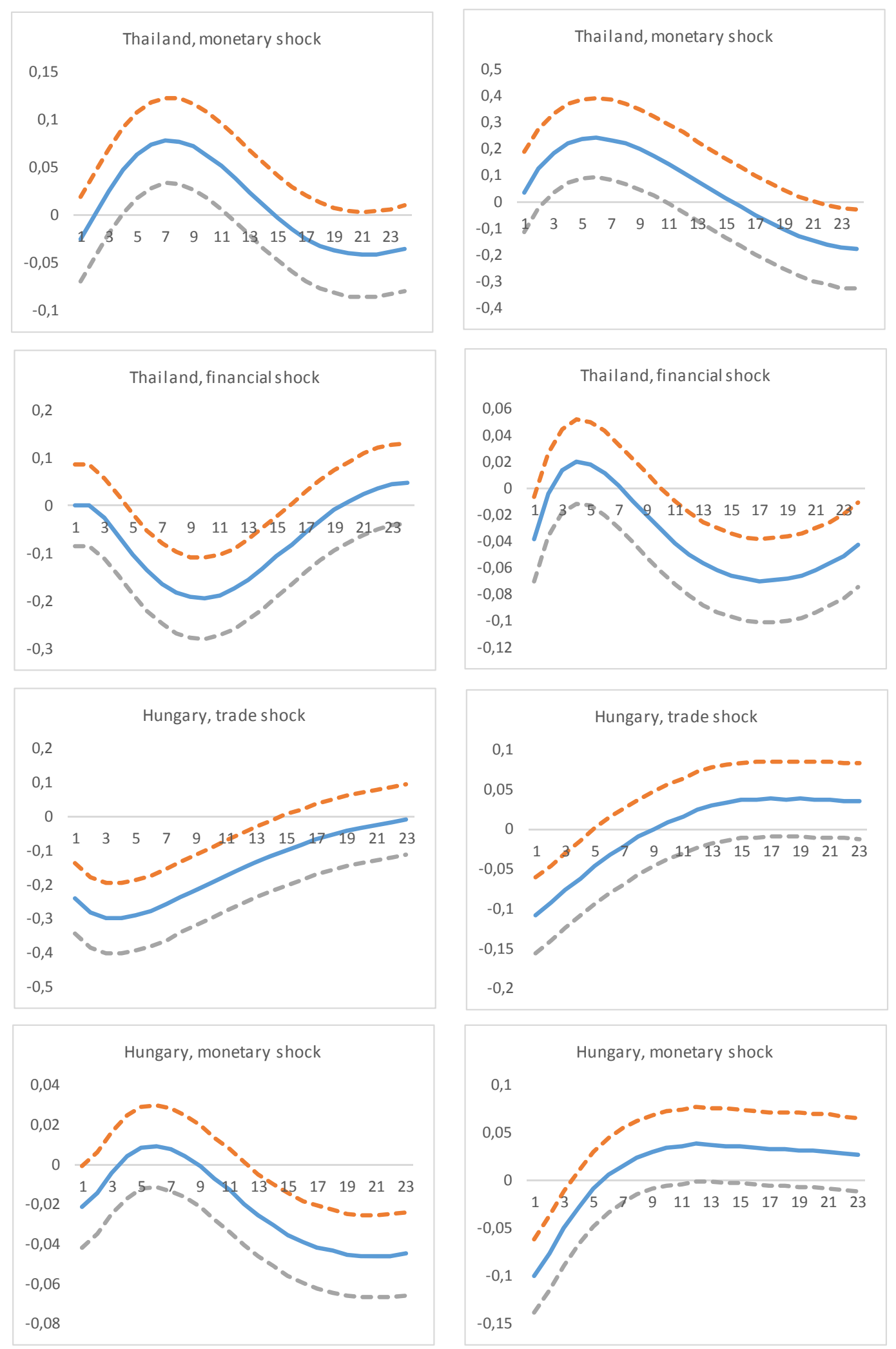

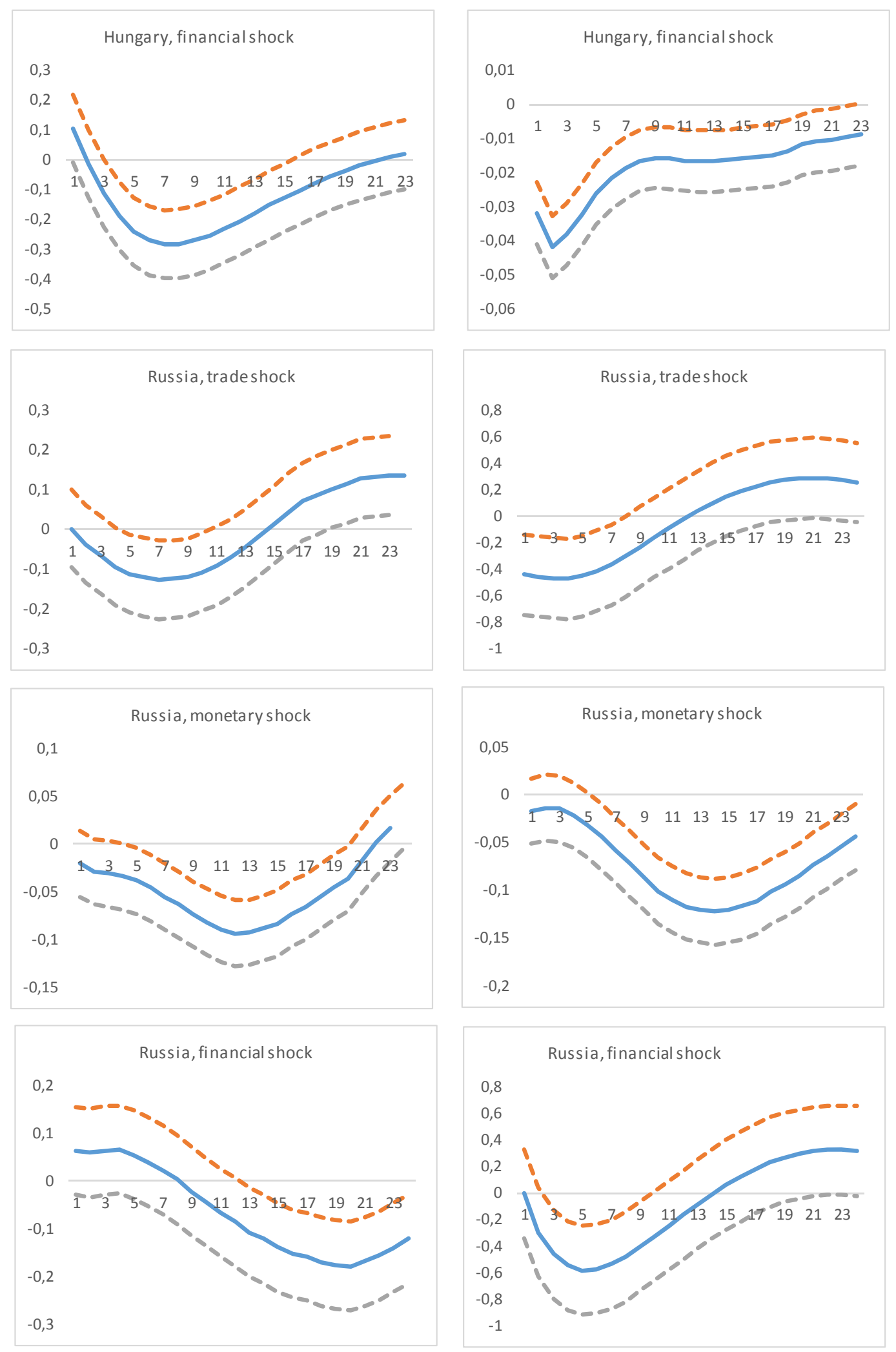

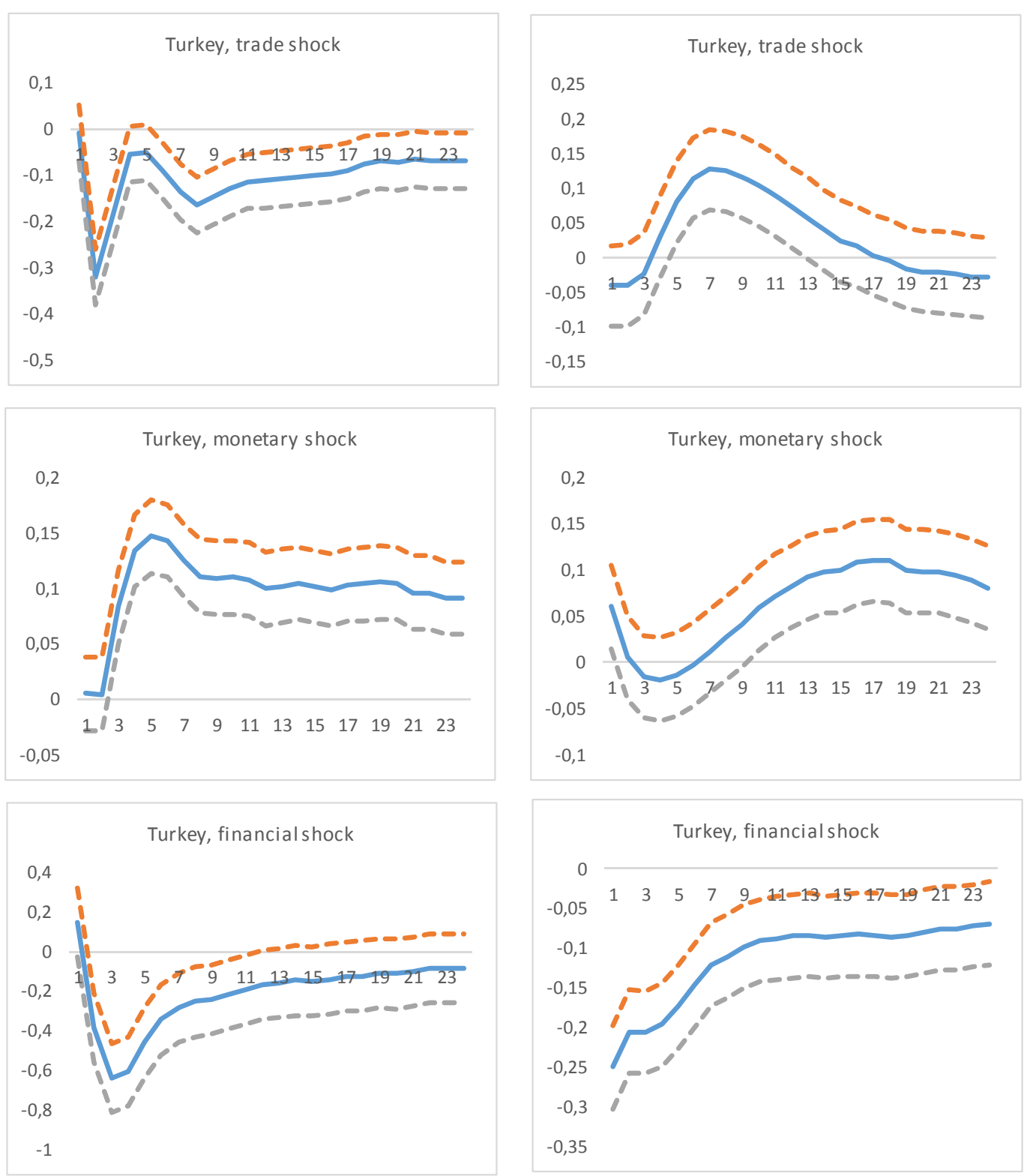